\title{
A continuidade do processo de desconcentração regional da indústria brasileira nos anos 2000
}

João Saboia

Professor titular do Instituto de Economia/UFRJ

\author{
Palauras-chave \\ indústria brasileira, \\ concentração regional da \\ indústria, emprego industrial.
}

Classificação JEL J21, L60, L70, O14, $\mathrm{R} 12$

\section{Key words}

Brazilian industry; Regional concentration of industry; Industrial Employment

JEL Classification J21; L60; L70; O14, R12

\section{Resumo}

$\mathrm{O}$ artigo dá continuidade ao debate sobre as mudanças locacionais da indústria brasileira nas últimas décadas. A partir dos dados de emprego e massa salarial da indústria de transformação e extrativa mineral no Brasil no período 1997/2007, é identificado um intenso processo de desconcentração regional. Utilizando índices clássicos de concentração, verifica-se que a tendência desconcentradora atinge todos os tipos de indústrias, sejam elas tradicionais, de commodities, difusoras ou de bens duráveis. $\mathrm{O}$ artigo propóe ainda a utilização de um novo índice de densidade, destacando algumas mesorregióes onde ele é relativamente elevado. A partir do cálculo do índice de densidade, são selecionadas oito mesorregióes em diferentes regiōes do país para ilustrar o processo de desconcentração regional da indústria.

\section{Abstract}

The article continues the debate on the changes in the regional distribution of Brazilian industry in recent decades. Based on industry data for employment and wages for the period 1997/2007, it identifies an intense process of regional decentralization. Using classical indices of concentration, it appears that the trend identified affects all types of industries, whether traditional, commodities, diffuser or durable goods. The article also proposes the use of a new density index, highlighting some meso-regions where it is relatively high. From the values encountered for the density index some meso-regions located in different regions of the country are selected and their results discussed, which illustrates various situations of apparent success. 


\section{1_Introdução}

O debate sobre o processo de desconcentração espacial da indústria nos últimas duas décadas tem início nos trabalhos pioneiros de Diniz (1993) e Diniz e Crocco (1996), que apontam para um movimento de desconcentração ocorrido entre as décadas de setenta e noventa. Segundo esses autores, teria havido perdas na participação das Regiōes Metropolitanas de São Paulo e do Rio de Janeiro ao longo daquele período. Em contrapartida, teria ocorrido aumento nos estados do Sul e de Minas Gerais, assim como no interior de São Paulo, surgindo uma espécie de polígono que ia do centro de Minas Gerais ao nordeste do Rio Grande do Sul. Assim, as transformaçōes ocorridas fariam com que o processo de desconcentração ficasse restrito às cidades localizadas no interior de tal polígono.

Outros autores como Negri (1994), Pacheco (1999), Saboia (2000) e outros argumentam que o processo de desconcentração não estava restrito ao referido polígono. Negri (1994), por exemplo, mostra que o processo de desconcentração beneficiou outras regióes como a Centro-Oeste, a região Nordeste e a Zona Franca de Manaus através do desenvolvimento de determinados setores industriais.

Pacheco (1999) defende que o processo de desconcentração prosseguiu até meados da década de noventa, com padróes setoriais que variam dependendo da região considerada. Segundo ele, entretanto, o processo de desconcentraçáo teria desacelerado em relação ao período anterior.

Andrade e Serra (2000) apontam para uma estagnação da participação dos municípios do polígono no emprego industrial na primeira metade dos anos 90 . No interior do polígono, entretanto, estaria ocorrendo um processo de desconcentração espacial com redução da importância das principais áreas industriais.

Saboia (2000) analisa o período 19891997. Confirma o movimento de desconcentração nas regiōes e estados, mostrando declínio do emprego industrial nas principais capitais e regiōes metropolitanas e o fortalecimento do interior dos principais estados industrializados e em alguns estados fora do eixo Sul-Sudeste. Com isso, estariam surgindo pequenas aglomerações industriais nas mais distintas regióes do país, caracterizadas por possuírem baixos salários e pequeno nível de diversificação industrial.

Azevedo e Toneto Júnior (2001) também defendem a continuação do processo de desconcentração na década de 90 . Segundo esse estudo, os setores intensivos em mão de obra estariam migrando para regiōes com baixos salários. No caso dos 
setores intensivos em recursos naturais, esses se deslocariam para locais com disponibilidade de tais recursos. Finalmente, as indústrias intensivas em capital estariam sofrendo a concorrência de regióes localizadas nos estados do Sul/Sudeste.

Saboia (2001) confirma os deslocamentos espaciais ocorridos na década de noventa, mostrando que a região Sul foi a principal beneficiária das mudanças, com crescimento relativo de sua participação no emprego e nos salários nos mais diversos setores industriais. Mostra também o aumento da importância das regióes Nordeste e Centro-Oeste em diversos segmentos da indústria tradicional.

Suzigan et al. (2001) e Azzoni (2002) estudam especificamente o caso de São Paulo. O primeiro discute a heterogeneidade das aglomeraçóes industriais paulistas e mostra melhor desempenho do interior relativamente à Região Metropolitana. Já o segundo defende que a Região Metropolitana de Sáo Paulo continuaria tendo papel fundamental no processo de industrializaçẫo.

Saboia (2004) discute a questão da desconcentração espacial da indústria no período 1994-2000 do ponto de vista da regiāo Nordeste. Segundo o autor, apesar da melhora ocorrida no período do ponto de vista da geração de emprego e do nível de remuneração, a posição da região continuava bastante desfavorável em relação ao restante do país. Ao mesmo tempo, destaca o grande diferencial existente no interior da própria regiáo.

Ramos e Ferreira (2005) comparam o comportamento diferenciado entre as metrópoles e o restante do país. Segundo os autores, estaria havendo esgotamento das metrópoles enquanto polos industriais, perdendo ainda espaço por conta da guerra fiscal entre estados. Com a perda de importância relativa do eixo Rio-Sáo Paulo, estaria havendo migração de postos de trabalho industriais para o interior de São Paulo e para os estados vizinhos.

Garcia, Lemos e Carvalho (2003) trabalham com um enfoque econômico-demográfico e apontam para importantes mudanças ocorridas nos principais polos econômicos do país nas últimas décadas, com destaque para os anos noventas. Pereira e Lemos (2003) e Lemos et al. (2003) analisam o desenvolvimento das cidades, concluindo que a distribuição espacial da indústria brasileira continua concentrada em São Paulo e em seu entorno. Segundo os autores, há o surgimento de polos subnacionais que, entretanto, possuem influência geográfica limitada.

Oliveira Júnior (2006) destaca os determinantes da decisão da localização industrial. Chega à conclusão de que a questáo locacional está fortemente associada 
às características de cada setor da indústria, como custos salariais, economias de aglomeração, proximidade do mercado e das plantas já existentes.

Com base em técnicas de estatística multivariada e indicadores sintéticos e de dados das mesorregióes do país, Saboia, Kubrusly e Barros (2008) confirmam que, em meados da década de 2000, os desequilíbrios regionais permaneciam elevados, beneficiando as regióes Sul e Sudeste. Foram, entretanto, encontrados resultados favoráveis em algumas mesorregióes do Norte, do Nordeste e do Centro-Oeste, o que confirmaria o ponto de vista de alguns autores aqui resenhados no sentido de uma extrapolação do processo de desconcentração para fora do polígono original de Diniz e Crocco em anos recentes. Há casos de desenvolvimento em regióes no entorno das capitais e outros em que se trata de políticas explícitas de atração de investimentos industriais para o interior.

Finalmente, Ardissone (2009) analisa as 58 microrregióes com maior valor da transformação industrial, concluindo que o processo de desconcentração ocorrido no período 1996/2005 depende muito do tipo de indústria considerado. Em alguns casos, houve tendência à desconcentração com o surgimento de outras microrregiôes. Em outros, teria havido reconcentração da indústria.
Este artigo persegue o mesmo tipo de preocupaçáo da maior parte dos trabalhos acima resenhados, atualizando a discussão da localização regional com dados recentes. Conforme será visto nas próximas seções, há forte evidência de que o processo de desconcentração regional da indústria estaria tendo continuidade no país, porém de forma diferenciada segundo a região e o setor considerados. Os diversos índices de concentração regional apresentam clara redução na última década. Podem ainda ser identificadas diversas mesorregióes de porte médio que têm se destacado pelo aumento da densidade de suas atividades industriais, especialmente na região Sul do país.

Além desta introdução, o artigo possui cinco outras seções. Na seção 2, é apresentado um quadro geral do processo recente de desconcentração regional da indústria no país. Em seguida, é feita uma análise da desconcentração segundo os vários segmentos da indústria. $\mathrm{Na}$ seção 4 , é proposto um novo índice que procura diferenciar a densidade da indústria em cada mesorregião. A seção 5 analisa o caso de três mesorregióes da regiáo Sul que se destacam pela alta participação da indústria em sua atividade econômica e de outras cinco mesorregióes localizadas em áreas menos desenvolvidas do país que apresentaram no passado recente excepcional crescimen- 
${ }^{1}$ Para dar mais segurança aos resultados encontrados neste artigo, foi feito um exercício com os dados setoriais da PIA 2008 a dois dígitos. O coeficiente de correlação entre massa de salários e VTI atingiu 0,85, e entre massa de salários e valor adicionado, 0,81. No caso da comparaçáo com o emprego, os valores encontrados foram, respectivamente, 0,58 e 0,51 .

Portanto, as duas variáveis utilizadas no artigo estão associadas positivamente tanto com o VTI quanto com o valor adicionado, especialmente no caso da massa salarial. to da atividade industrial. Finalmente, são mostradas as principais conclusóes do trabalho. $\mathrm{O}$ artigo possui ainda quatro anexos com tabelas selecionadas que complementam os dados discutidos ao longo do texto.

\section{Um quadro geral do recente processo de desconcentração regional}

É comum os estudos sobre concentração industrial no Brasil utilizarem como variável básica o valor da transformação industrial (VTI). Alternativamente, podem ser usadas outras variáveis, dependendo da fonte de dados disponível. Saboia (2001) mostrou, valendo-se de dados levantados no Censo Industrial, na Pesquisa Industrial Anual do IBGE e na RAIS, que a distribuição regional do VTI e da massa salarial é muito semelhante. Tal resultado não chega a representar surpresa na medida em que maiores quantidades de valor adicionado (ou VTI) em determinada região permitem o pagamento de maior volume de salários para maior número de empregados. Por outro lado, foi também verificado que o nível de concentração regional da massa salarial é mais alto do que quando considerado o nível de emprego, na medida em que as regióes mais desenvolvidas costumam pagar salários mais elevados. Estudando o nível de concentração regional dos municípios brasileiros, Lemos et al. (2005) encontraram o mesmo padrão de concentração utilizando o VTI ou o emprego. Conforme esperado, o nível de concentração é mais elevado com a primeira variável.

A fonte de dados utilizada neste artigo é a RAIS, que apresenta informaçóes regionais em níveis bastante desagregados. Ela permite o uso tanto da variável emprego quanto dos salários para se medir a concentração industrial. Privilegiou-se a utilizaçáo do emprego, complementando-se com informaçôes sobre o nível de concentração obtido com a massa salarial. Conforme será visto adiante, efetivamente, o nível de concentração regional obtido com a primeira variável é mais baixo do que com a segunda, mas os movimentos verificados no sentido da desconcentração são exatamente os mesmos. Como o principal interesse deste estudo é observar "mudanças" e não "níveis", foi dada preferência à análise com a variável emprego, que possui interesse particular por si própria. ${ }^{1}$

O período a ser estudado se inicia em 1997, correspondendo ao final do período analisado em Saboia (2000), considerando-se os dados da indústria de transformação e extrativa mineral. $\mathrm{O}$ corte regional utilizado é composto das 137 mesorregióes do país, permitindo informações em nível intermediário de desagregação necessá- 
rio para a análise do processo de desconcentração industrial. ${ }^{2} \mathrm{O}$ final do período é 2007, representando, portanto, a evolução ao longo de uma década. Evitou-se incluir o ano de 2008 para evitar possíveis efeitos da crise internacional que se abateu com força sobre a indústria brasileira no último trimestre daquele ano. ${ }^{3}$

O processo de desconcentração espacial da indústria teve continuidade nos anos recentes. Utilizando-se como variável o emprego ou os salários da indústria nas mesorregióes no período 1997/2007, nota-se redução do índice de Gini locacional. Os valores encontrados para o emprego foram, respectivamente, $0,73 \mathrm{e}$ 0,68. Ao se considerar a massa de salários, a queda do Gini foi de 0,88 e $0,77 .{ }^{4}$ Conseqüentemente, a curva de Lorenz deslocou-se para cima e se aproximou da reta de perfeita igualdade (Gráfico 1).

As mudanças na distribuição do emprego poderiam eventualmente estar associadas a movimentos migratórios ocorri-

\section{Gráfico 1_Curva de Lorenz do emprego - 1997/2007}

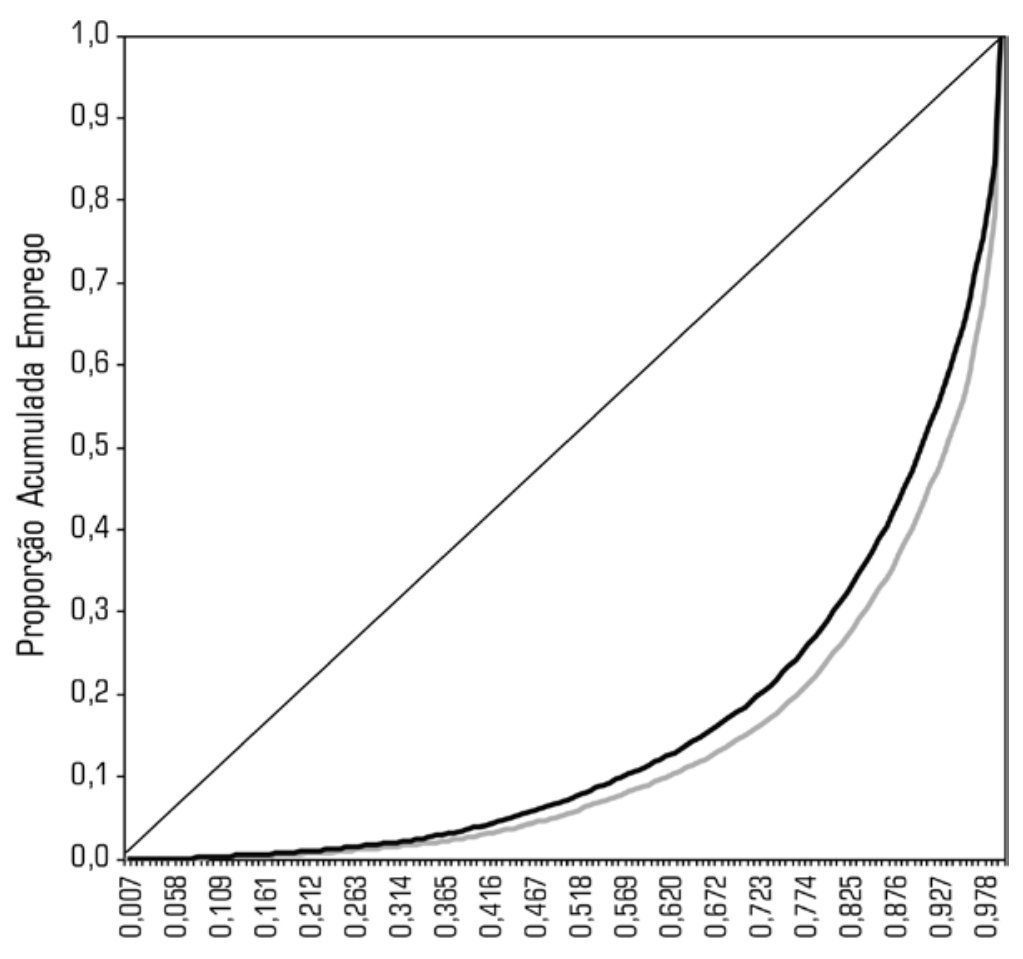

Proporção Acumulada Mesorregiões

\begin{tabular}{|c|c|c|c|}
\hline $\begin{array}{l}{ }^{2} \text { Uma alternativa seria } \\
\text { utilizar as microrregióes } \\
\text { como em Saboia (2000) e }\end{array}$ & $\begin{array}{l}\text { delas acaba sendo descartada } \\
\text { na análise, perdendo-se } \\
\text { muita informação. } \mathrm{O}\end{array}$ & $\begin{array}{l}\text { possibilidade de se considerar } \\
\text { a maior parte delas (ou, } \\
\text { eventualmente, todas). }\end{array}$ & $\begin{array}{l}\text { Herfindahl). O índice de } \\
\text { Gini serve apenas como } \\
\text { primeira referência ilustrativa }\end{array}$ \\
\hline $\begin{array}{l}\text { Ardissone (2009). O número } \\
\text { de microrregióes, entretanto, } \\
\text { é muito elevado ( } 556 \text { ), e, } \\
\text { como um grande número de } \\
\text { microrregióes possui pequena } \\
\text { importância em termos } \\
\text { industriais, a maior parte }\end{array}$ & $\begin{array}{l}\text { primeiro estudo mencionado } \\
\text { utilizou os dados de } 155 \\
\text { microrregióes, e o segundo, } \\
\text { de apenas } 58 \text {. Ao se trabalhar } \\
\text { com as mesorregióes, cujo } \\
\text { número é bem menor (137) } \\
\text { que o de microrregióes, há a }\end{array}$ & $\begin{array}{l}{ }^{3} \text { Cabe lembrar que os dados } \\
\text { da RAIS são do dia } 31 \text { de } \\
\text { dezembro de cada ano. } \\
{ }^{4} \text { São utilizadas neste trabalho } \\
\text { medidas de desigualdade } \\
\text { (Gini) e de concentração } \\
\text { (razões de concentração e }\end{array}$ & $\begin{array}{l}\text { para o movimento de } \\
\text { desconcentraçáo observado. } \\
\text { Como será visto adiante, } \\
\text { todos os índices mostram a } \\
\text { mesma tendência no sentido } \\
\text { da desconcentraçáo espacial } \\
\text { no período analisado. }\end{array}$ \\
\hline
\end{tabular}




\section{Gráfico 2_Mesorregióes por emprego - 1997/2007}

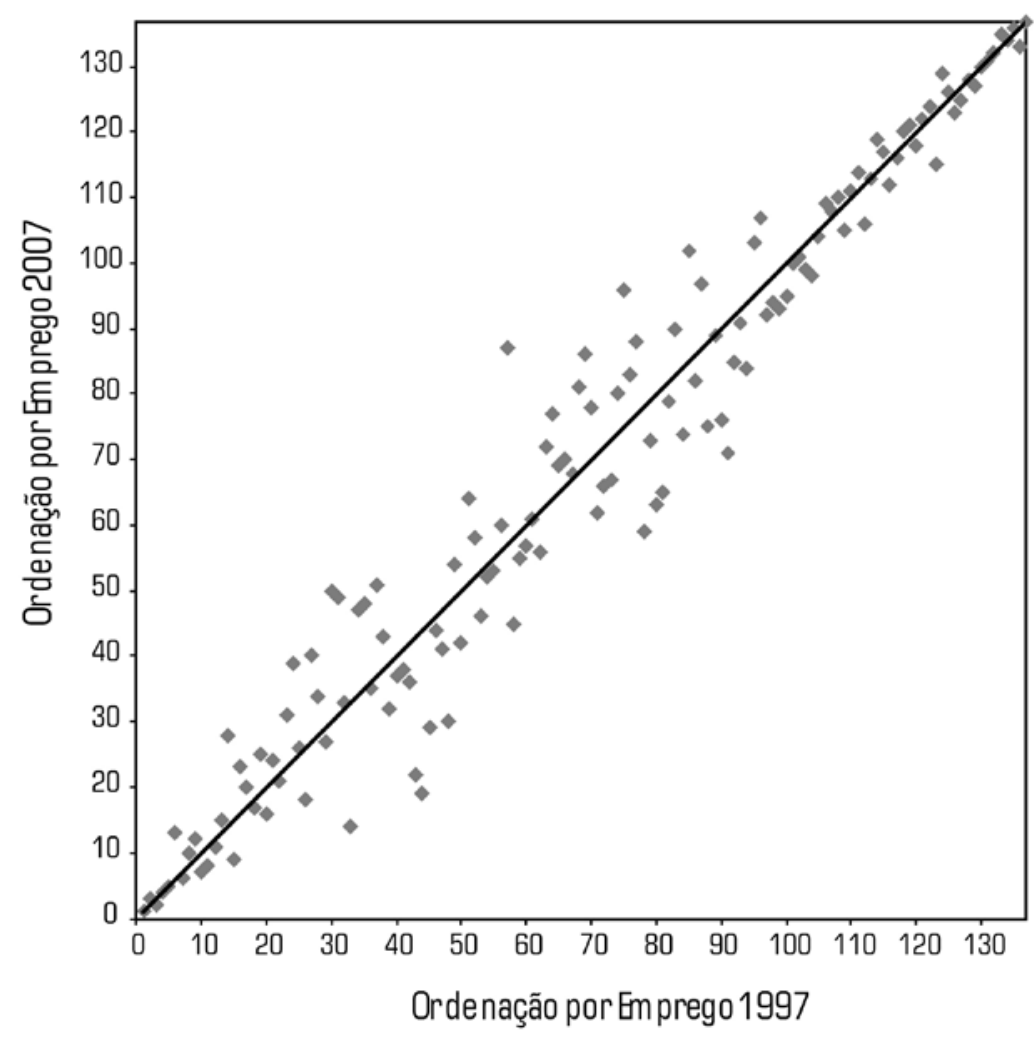

Fonte: RAIS

${ }^{5}$ A ordenaçãa foi feita de tal forma que as mesorregiōes com mais empregos são representadas por números de ordem maiores. dos entre as populaçóes das mesorregióes. Tal, entretanto, não parece ter sido o fato na medida em que o índice de Gini da distribuição mesorregional da população residente permaneceu praticamente estável no período (0,509 em 1997, e 0,511 em 2007). Conforme esperado, tanto a distribuição do emprego quanto a dos salários é muito mais concentrada regionalmente do que a distribuição da população, o que é confirmado pelos maiores valores do índice de Gini para as variáveis emprego e salários.

Os dados sobre a evolução do nível de emprego na indústria são significativos, mostrando forte crescimento no período. Em 1997, havia 4.770 mil vínculos empregatícios na indústria, passando

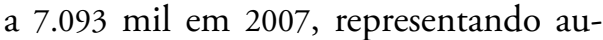
mento de quase $50 \%$ (i.e. taxa de $4 \%$ de crescimento ao ano).

Uma forma alternativa de se verificar as modificaçóes na distribuição do emprego entre as mesorregióes é através do Gráfico 2, no qual as 137 mesorregióes estáo ordenadas nos dois eixos segundo o nível de emprego industrial em 1997 e 2007..$^{5}$ Conforme pode ser verificado, houve forte dinamismo no período, com importantes mudanças na ordenação das mesorregióes segundo o volume de emprego. Os pontos abaixo da reta representam mesorregióes que perderam posição e vice-versa. Cabe notar que as principais mudanças ocorreram nas mesorregióes posicionadas na parte central da distribuição. No caso das maiores mesorregióes, as mudanças de ordenação são relativamente pequenas.

Alguns exemplos ilustram as mudanças ocorridas no período. Entre aquelas que 
melhoraram sua posição em termos de volume de emprego, podem ser mencionadas as mesorregióes Centro-Sul Baiano $(+30$ posições), Norte Fluminense $(+21)$ e Oeste Paranaense $(+11)$. Entre as que pioraram, Litoral Sul Paulista (-21), Sudeste Rio-Grandense (-20) e Centro-Sul Paranaense (-19). Em outras palavras, há situaçóes diferenciadas no interior de um mesmo estado ou de uma região natural. Conforme salientado por Ardissone (2009), tais mudanças provavelmente refletem a composição da indústria local, beneficiando as mesorregióes onde houve maior expansão das indústrias localizadas em seu interior, ocorrendo o inverso para as que concentram indústrias com menos dinamismo.

Em 2007, as 25 mesorregióes com o maior volume de empregos eram responsáveis por 4.874 mil vínculos empregatícios ou $68,7 \%$ do total do país. ${ }^{6}$ Apesar da perda relativa de importância, a Região Metropolitana de São Paulo ainda representava $15,8 \%$ do emprego industrial. Apenas seis das 25 principais mesorregióes industriais estavam fora das regiōes Sul/Sudeste, sendo três Regióes Metropolitanas nordestinas (Fortaleza, Salvador e Recife). As demais ficam na regiâo Centro-Oeste (Centro Goiano), Norte (Centro Amazonense) e Nordeste (Leste Alagoano). A primeira inclui
Goiânia, a segunda, Manaus, e a terceira, é uma zona importante da agroindústria da cana de açúcar (ver Tabela 1).

Apenas uma mesorregião entre as 25 com maior nível de emprego em 1997 saiu do grupo das principais em 2007. Trata-se da Zona da Mata, substituída pelo Triângulo Mineiro/Alto Parnaíba, ambas em Minas Gerais. Houve, entretanto, mudanças de ordenação em seu interior, como no caso das Regiōes Metropolitanas do Rio de Janeiro e de Recife, que perderam posições, e o Centro Amazonense, que ganhou. Cabe ainda mencionar a forte redução da participação das 25 principais mesorregióes industriais no emprego total, na medida em que em 1997 elas representavam $74 \%$ do total, reduzindo para $68,7 \%$, conforme mencionado. Tal resultado ilustra a tendência à redução da concentração regional da indústria no período.

Analisando-se o interior das 25 principais mesorregióes industriais no período, chama a atenção o fato de que a perda relativa em termos de emprego está concentrada nas quatro principais Regióes Metropolitanas do país - São Paulo, Rio de Janeiro, Porto Alegre e Belo Horizonte. Juntas elas representavam $37,2 \%$ do emprego em 1997 e 28\% em 2007. Apesar da queda, o fato de apenas quatro mesorregióes possuírem quase 30\% do empre-
${ }^{6}$ As 37 principais mesorregióes representavam $80 \%$ do emprego industrial em 2007, enquanto as 59 maiores atingiam $90 \%$. 
Tabela 1_As 25 mesorregiões com maior número de empregos - 1997/2007

\begin{tabular}{|c|c|c|c|c|c|c|c|}
\hline$\ddot{\text { UF }} \cdots$ & Mesorregião & Empregos & $\%$ & UF & Mesorregião & Empregos & $\ddot{\%}$ \\
\hline SP & Metropolitana de São Paulo & 1.049 .531 & 22,0 & SP & Metropolitana de São Paulo & 1.121 .561 & 15,8 \\
\hline RJ & Metropolitana do Rio de Janeiro & 260.772 & 5,5 & RS & Metropolitana de Porto Alegre & 315.653 & 4,4 \\
\hline RS & Metropolitana de Porto Alegre & 245.855 & 5,2 & SP & Campinas & 302.869 & 4,3 \\
\hline MG & Metropolitana de Belo Horizonte & 215.659 & 4,5 & MG & Metropolitana de Belo Horizonte & 283.458 & 4,0 \\
\hline SP & Campinas & 200.990 & 4,2 & RJ & Metropolitana do Rio de Janeiro & 266.051 & 3,8 \\
\hline SP & Macro Metropolitana Paulista & 139.994 & 2,9 & SP & Macro Metropolitana Paulista & 217.949 & 3,1 \\
\hline PR & Metropolitana de Curitiba & 122.788 & 2,6 & PR & Metropolitana de Curitiba & 195.522 & 2,8 \\
\hline SC & Vale do Itajaí & 95.806 & 2,0 & SC & Vale do Itajaí & 176.264 & 2,5 \\
\hline RS & Nordeste Rio-Grandense & 94.894 & 2,0 & SP & Ribeirão Preto & 156.051 & 2,2 \\
\hline SC & Norte Catarinense & 94.000 & 2,0 & SC & Norte Catarinense & 154.862 & 2,2 \\
\hline $\mathrm{CE}$ & Metropolitana de Fortaleza & 89.156 & 1,9 & RS & Nordeste Rio-Grandense & 148.876 & 2,1 \\
\hline SP & Vale do Paraíba Paulista & 86.523 & 1,8 & SP & Piracicaba & 145.784 & 2,1 \\
\hline SP & Piracicaba & 86.184 & 1,8 & CE & Metropolitana de Fortaleza & 137.467 & 1,9 \\
\hline SP & Ribeirão Preto & 78.834 & 1,7 & PR & Norte Central Paranaense & 136.126 & 1,9 \\
\hline $\mathrm{PE}$ & Metropolitana de Recife & 76.888 & 1,6 & SP & Vale do Paraíba Paulista & 123.843 & 1,7 \\
\hline PR & Norte Central Paranaense & 74.440 & 1,6 & MG & Sul/Sudoeste de Minas & 123.702 & 1,7 \\
\hline MG & Sul/Sudoeste de Minas & 70.222 & 1,5 & GO & Centro Goiano & 109.666 & 1,5 \\
\hline $\mathrm{AL}$ & Leste Alagoano & 61.271 & 1,3 & SC & Oeste Catarinense & 108.813 & 1,5 \\
\hline GO & Centro Goiano & 59.229 & 1,2 & AM & Centro Amazonense & 107.766 & 1,5 \\
\hline SC & Oeste Catarinense & 59.209 & 1,2 & AL & Leste Alagoano & 98.137 & 1,4 \\
\hline SP & Bauru & 58.079 & 1,2 & BA & Metropolitana de Salvador & 94.442 & 1,3 \\
\hline MG & Zona da Mata & 54.556 & 1,1 & SP & Bauru & 93.985 & 1,3 \\
\hline BA & Metropolitana de Salvador & 54.212 & 1,1 & PE & Metropolitana de Recife & 89.264 & 1,3 \\
\hline $\mathrm{AM}$ & Centro Amazonense & 53.978 & 1,1 & MG & Triângulo Mineiro/Alto Paranaíba & 84.994 & 1,2 \\
\hline RS & Noroeste Rio-Grandense & 47.736 & 1,0 & RS & Noroeste Rio-Grandense & 80.814 & 1,1 \\
\hline Subtotal & & 3.530 .806 & 74,0 & Subtotal & & 4.873 .919 & 68,7 \\
\hline Total & & 4.769.855 & 100,0 & Total & & 7.093.368 & 100,0 \\
\hline
\end{tabular}

Fonte: RAIS 
go total continua sendo um fato importante, confirmando os desníveis regionais existentes na indústria. As demais 21 mesorregióes desse grupo tiveram sua participação aumentada de $36,8 \%$ para $40,7 \%$ do total. Esse resultado é muito importante para que se possa qualificar melhor o processo de desconcentração espacial da indústria verificado no país no período.

$\mathrm{Na}$ Tabela 2, a distribuição do emprego é apresentada segundo seis grupos de mesorregióes, ordenados pelo volume de emprego em seu interior. Verifica-se com clareza que a perda relativa se concentra apenas nas cinco maiores, com forte redução da parcela do emprego, de 41,4\% para 32,3\%. Nesse grupo, apenas Campinas teve aumento na participação relativa, subindo da quinta para a terceira posição entre as mesorregióes que mais geram empregos no país. Os demais grupos aumentaram sua importância relativa, especialmente o segundo e o terceiro. ${ }^{7}$ Mesmo o grupo de 37 mesorregióes com o menor volume de emprego industrial tiveram aumento de participação, mais que dobrando o número de empregos no período.

Para efeito de comparação, a Tabela 3 apresenta a distribuiçáo da massa de salários nos seis grupos de mesorregióes considerados. A complementação da análise dos dados de emprego com informações sobre os salários procura dar mais
Tabela 2_Distribuição do emprego por grupos de mesorregióes - 1997/2007

\begin{tabular}{|c|c|c|c|c|}
\hline \multirow{2}{*}{ Mesorregiões } & \multicolumn{2}{|c|}{1997} & \multicolumn{2}{|c|}{2007} \\
\hline & Empregos & $\%$ & Empregos & $\%$ \\
\hline 5 maiores & 1.972 .807 & 41,4 & 2.289 .592 & 32,3 \\
\hline 20 seguintes & 1.557 .999 & 32,7 & 2.584 .327 & 36,4 \\
\hline 25 seguintes & 730.972 & 15,3 & 1.274 .381 & 18,0 \\
\hline 25 seguintes & 323.447 & 6,8 & 572.691 & 8,1 \\
\hline 25 seguintes & 132.559 & 2,8 & 265.067 & 3,7 \\
\hline 37 seguintes & 52.071 & 1,1 & 107.310 & 1,5 \\
\hline Total & 4.769 .855 & 100,0 & 7.093.368. & 100,0 \\
\hline
\end{tabular}

Fonte: RAIS

força aos resultados encontrados na medida em que a massa de salários está mais associada ao valor adicionado pela indústria do que o volume de emprego. Conforme mencionado, o nível de concentração é mais elevado com a utilização dos salários pagos em vez do emprego, mas a tendência à desconcentração é nítida com a perda de participação limitada ao grupo das cinco principais mesorregióes, por sinal, as mesmas listadas acima na análise por emprego. Os cinco outros grupos tiveram crescimento em sua participação no total de salários pagos na indústria no período. ${ }^{8}$

Concluindo, pode-se afirmar que o processo de desconcentração industrial foi intenso no período, com perda limi-
${ }^{7}$ No Anexo A, são apresentados os resultados detalhados da distribuição do emprego segundo as mesorregióes dos seis grupos considerados.

${ }^{8}$ Os salários estão informados em salários mínimos (SM), considerando-se o pagamento de 13 salários no ano. Tendo em vista o aumento do nível do SM de 64\%, houve redução do número da SMs pagos no período. Apesar disso, houve crescimento real da massa salarial da ordem de $44 \%$. 
Tabela 3_Distribuição dos salários por mesorregiões - 1997/2007

\begin{tabular}{|c|c|c|c|c|}
\hline Mesorregiões & Salários" & $\%$ & Salários: & $\%$ \\
\hline 5 maiores & 206.307 .349 & 54,0 & 143.686 .563 & 42,9 \\
\hline 20 seguintes & 116.378.106 & 30,5 & 118.789 .710 & 35,5 \\
\hline 25 seguintes & 38.803 .222 & 10,2 & 45.119 .922 & 13,5 \\
\hline 25 seguintes & 13.551 .370 & 3,5 & 16.810 .099 & 5,0 \\
\hline 25 seguintes & 5.158 .537 & 1,4 & 7.540 .127 & 2,3 \\
\hline 37 seguintes & 1.585 .061 & 0,4 & 2.646 .007 & 0,8 \\
\hline Total & 381.783 .645 & 100,0 & 334.592 .427 & 100,0 \\
\hline
\end{tabular}

Fonte: RAIS

(*) Massa salarial em salários mínimos do ano acordo com Ardissone (2009), seria diferenciado segundo os diversos setores industriais.

Conforme a Tabela 4, não houve grandes mudanças na distribuição do emprego no interior da indústria, no período 1997/2007. Fabricação de alimentos e bebidas absorve cerca de $20 \%$ do emprego total, com pequena elevação. Outros segmentos da indústria tradicional como Fabricação de Produtos Têxteis, Confecção de Artigos de Vestuário, Preparaçáo de Couro e Fabricação de Artigos de Couro, Fabricaçáo de Produtos de Madeira, Fabricação de Móveis, Edição e Impressão e Fabricação de Artigos de Borracha e Plástico são importantes geradores de emprego, apresentando pequenas modificações relativas no período. Os segmentos da indústria extrativa usualmente geram poucos empregos. Cabe ainda mencionar a importância de alguns segmentos da indústria mais avançada em termos tecnológicos na geração de emprego, como no caso da Fabricação e Montagem de Veículos Automotores e Fabricação de Máquinas e Equipamentos. De qualquer forma, a regra geral no período foi de relativa manutenção da distribuiçáo do emprego, segundo os diversos segmentos industriais.

Ao se calcularem os índices de concentração mesorregional do emprego nas 27 divisóes da indústria, verifica-se que, com 
pouquíssimas exceções, houve desconcentração no período. Além do índice de Gini, foram utilizados o índice de Herfindahl (HHI) e quatro razóes de concentração. ${ }^{?}$

A indústria foi ainda agregada segundo quatro grupos bem distintos - commodities; difusoras; tradicionais; e duráveis - segundo classificação desenvolvida por Ferraz, Kupfer e Haguenauer (1996).

Os quatro grupos têm as seguintes características:

a_commodities: indústrias de processo contínuo que elaboram produtos homogêneos em grande volume;

b_difusoras: indústrias do novo paradigma tecnológico, constituindo a base do progresso técnico para o restante da indústria, sendo fundamental para o avanço da competitividade da indústria como um todo;

c_bens duráveis: indústrias de montagem em larga escala formadas por produtores de bens de consumo durável cuja característica maior é a forte incorporação de densidade tecnológica em seus produtos;

d_tradicionais: indústrias que se caracterizam por elaborar produtos de menor conteúdo tecnológico destinados principalmente ao consumo final. Utilizam inovaçóes geradas nos demais setores da indústria.

A separação da indústria em poucos grupos com certo grau de homogeneidade facilita bastante a análise dos resultados. Conforme mencionado acima, as informações da indústria são fornecidas em 27 divisóes, o que tornaria a análise desnecessariamente trabalhosa.

Tendo em vista o nível de desagregação utilizado com a classificação de divisões, não foi possível separar a indústria difusora da de bens duráveis na medida em que algumas divisões possuem indústrias dos dois tipos. Assim, neste trabalho, as divisões da indústria foram classificadas em três grupos: commodities, difusoras/duráveis e tradicionais.

Os resultados são inequívocos, apontando para nítida desconcentraçáo mesorregional do emprego industrial, independentemente do tipo de indústria considerada. Utilizando-se, por exemplo, o CR10, há queda de $55,5 \%$ para $47,8 \%$ no segmento de commodities; de $76,7 \%$ para $68,5 \%$ nos difusores/duráveis; e de $48,5 \%$ para $40,8 \%$ nos tradicionais (Tabela 5).

Apenas no caso de algumas divisóes da indústria extrativa mineral a tendência de desconcentração não é clara, com re-

\footnotetext{
${ }^{9}$ Foram calculadas razões de concentração (CRs) para 1, 5 , 10 e 25 principais mesorregiōes ordenadas pelo nível de emprego ou de salário.
} 
Tabela 4_Distribuição do emprego e dos salários por divisão - 1997/2007

\begin{tabular}{|c|c|c|c|c|c|c|c|c|}
\hline Atividades Industriais & Empregos & $\%$ & Salários" & $\%$ & Empregos & $\%$ & 007 Salários" & $\%$ \\
\hline Extração carvão mineral & 4.747 & 0,1 & 363.450 & 0,1 & 5.534 & 0,1 & 273.057 & 0,1 \\
\hline Extração de petroleo e serviços relacionados & 8.132 & 0,2 & 1.774 .794 & 0,5 & 50.288 & 0,7 & 14.982 .341 & 4,5 \\
\hline Extração de minerais metálicos & 27.601 & 0,6 & 3.446 .446 & 0,9 & 50.122 & 0,7 & 3.853 .308 & 1,2 \\
\hline Extração minerais não metálicos & 65.345 & 1,4 & 3.446 .646 & 0,9 & 79.500 & 1,1 & 2.795 .177 & 0,8 \\
\hline Fabricação de produtos alimentícios e bebidas & 895.971 & 18,8 & 52.718 .988 & 13,8 & 1.449 .672 & 20,4 & 48.870 .127 & 14,6 \\
\hline Fabricação de produtos do fumo & 20.870 & 0,4 & 2.293 .031 & 0,6 & 16.211 & 0,2 & 1.292 .911 & 0,4 \\
\hline Fabricação de produtos têxteis & 276.292 & 5,8 & 16.268 .073 & 4,3 & 335.081 & 4,7 & 11.263 .792 & 3,4 \\
\hline Confecção de artigos do vestuário e acessórios & 343.000 & 7,2 & 13.068 .281 & 3,4 & 591.226 & 8,3 & 13.114 .784 & 3,9 \\
\hline Preparação de couros e fabricação de artefatos de couro & 238.843 & 5,0 & 9.416 .069 & 2,5 & 394.509 & 5,6 & 9.400 .923 & 2,8 \\
\hline Fabricação de produtos de madeira & 193.702 & 4,1 & 6.829 .180 & 1,8 & 224.136 & 3,2 & 5.900 .635 & 1,8 \\
\hline Fabricação de celulose, papel e produtos de papel & 118.305 & 2,5 & 11.169 .796 & 2,9 & 158.676 & 2,2 & 9.401 .932 & 2,8 \\
\hline Ediçâo, impressão e reprodução de gravaçôes & 195.471 & 4,1 & 19.866 .383 & 5,2 & 217.534 & 3,1 & 11.637 .552 & 3,5 \\
\hline $\begin{array}{l}\text { Fabricação de coque, refino de petróleo, } \\
\text { elaboraçấo de combustíveis nucleares }\end{array}$ & 64.938 & 1,4 & 5.597 .307 & 1,5 & 107.800 & 1,5 & 7.366 .525 & 2,2 \\
\hline Fabricação de produtos químicos & 259.095 & 5,4 & 37.081 .863 & 9,7 & 338.303 & 4,8 & 30.449 .042 & 9,1 \\
\hline Fabricação de artigos de borracha e plástico & 248.044 & 5,2 & 18.813 .894 & 4,9 & 403.386 & 5,7 & 17.315 .589 & 5,2 \\
\hline Fabricação de produtos de minerais não metálicos & 258.717 & 5,4 & 14.495 .335 & 3,8 & 340.324 & 4,8 & 11.273 .422 & 3,4 \\
\hline Metalurgia básica & 214.417 & 4,5 & 25.830 .398 & 6,8 & 249.070 & 3,5 & 17.335 .692 & 5,2 \\
\hline $\begin{array}{l}\text { Fabricação de produtos de metal - } \\
\text { exclusive máquinas e equipamentos }\end{array}$ & 285.163 & 6,0 & 21.381 .107 & 5,6 & 455.588 & 6,4 & 19.491 .427 & 5,8 \\
\hline Fabricação de máquinas e equipamentos & 250.182 & 5,2 & 27.431 .560 & 7,2 & 439.361 & 6,2 & 27.545 .180 & 8,2 \\
\hline $\begin{array}{l}\text { Fabricação de máquinas para escritório e } \\
\text { equipamentos de informática }\end{array}$ & 16.463 & 0,3 & 2.301 .177 & 0,6 & 41.137 & 0,6 & 2.421 .450 & 0,7 \\
\hline Fabricação de máquinas, aparelhos e materiais elétricos & 120.637 & 2,5 & 12.337 .442 & 3,2 & 183.164 & 2,6 & 9.806 .918 & 2,9 \\
\hline $\begin{array}{l}\text { Fabricação de material eletrônico e de aparelhos e } \\
\text { equipamentos de computadores }\end{array}$ & 64.511 & 1,4 & 7.835 .755 & 2,1 & 86.443 & 1,2 & 5.090 .561 & 1,5 \\
\hline $\begin{array}{l}\text { Fabricaçáo de equipamentos de instrumentaçáo } \\
\text { para uso medico-hospitalar }\end{array}$ & 37.108 & 0,8 & 3.395 .831 & 0,9 & 57.603 & 0,8 & 3.112 .461 & 0,9 \\
\hline $\begin{array}{l}\text { Fabricação e montagem de veículos automotores, } \\
\text { reboques e carrocerias }\end{array}$ & 282.911 & 5,9 & 48.557 .454 & 12,7 & 406.701 & 5,7 & 33.471 .433 & 10,0 \\
\hline Fabricação de outros equipamentos de transporte & 30.899 & 0,6 & 3.764 .809 & 1,0 & 88.577 & 1,2 & 7.582 .800 & 2,3 \\
\hline Fabricação de móveis e indústrias diversas & 241.408 & 5,1 & 11.859 .036 & 3,1 & 298.804 & 4,2 & 8.863 .131 & 2,6 \\
\hline Reciclagem & 7.083 & 0,1 & 439.694 & 0,1 & 24.618 & 0,3 & 680.420 & 0,2 \\
\hline Total & 4.769 .855 & 100,0 & 381.783 .799 & 100,0 & 7.093 .368 & 100,0 & 334.592 .588 & 100,0 \\
\hline
\end{tabular}


sultados ambíguos, conforme o índice e a divisão considerada. Tendo em vista as características da indústria extrativa que depende da existência de jazidas no local da exploração, não seria mesmo de se esperar profundas mudanças em um período de apenas uma década. O processo de desconcentração só não aparece de forma nítida em poucas divisóes da indústria de transformação como no refino de petróleo, fabricação de outros produtos de fumo, fabricação de produtos de madeira e fabricação de outros equipamentos de transporte.

Para efeito de comparação são também apresentados os dados dos respectivos índices de concentraçáo quando utilizada a massa de salários na Tabela 6. Conforme esperado, os resultados mostram maior nível de concentração para os salários do que para o emprego, mas a tendência à desconcentração da massa de salários é nítida, semelhante à observada para o emprego.

Os Gráficos 3, 4 e 5 ilustram o processo de desconcentração nos três tipos de indústria utilizando os seis índices considerados para a variável emprego. ${ }^{10}$

Se por um lado foi constatada a redução da concentração regional do emprego e da massa de salários industriais, por outro se nota que os setores tradicionais e de commodities são bem menos concentrados que os difusores/duráveis. Em outras palavras, conforme esperado, os índices de concentração permanecem mais elevados nos segmentos industriais associados ao novo paradigma tecnológico que concentram as inovaçóes, nos quais os níveis de produtividade são mais altos. Mas também neles foi verificado intenso processo de redução dos desníveis regionais.

Para finalizar esta seção, são apresentados a seguir os dados da distribuição do emprego e dos salários, segundo as seis faixas de tamanho das mesorregióes utilizadas na última seção, para os três tipos de indústria, de modo a verificar até que ponto o processo de desconcentraçáo está associado à perda de importância das principais mesorregióes e ganho nas demais.

Conforme pode ser verificado nas Tabelas 7 e 8, o mesmo comportamento identificado para o conjunto da indústria se repete quando consideradas separadamente a indústria de commodities, a difusora/durável e a tradicional.

Consideremos inicialmente a variável emprego. Há forte perda entre as cinco maiores mesorregióes industriais e ganho nas demais nos três grupos de indústria considerados. No caso de commodities, as mesorregióes que mais se beneficiaram foram aquelas do terceiro grupo, i.e. da $26^{\mathrm{a}}$ à $50^{\mathrm{a}}$. $\mathrm{Na}$ indústria difusora/ durável, os maiores ganhos estão associados a importantes mesorregióes industriais do país, da 6a à 25a , que em 2007

\footnotetext{
${ }^{10}$ Os índices nos três gráficos são apresentados numa escala em que o valor $100 \%$ representa o máximo teórico do respectivo índice.
} 
Tabela 5 Índices de concentração espacial por divisão segundo o emprego - 1997/2007

\begin{tabular}{|c|c|c|c|c|c|c|c|c|c|c|c|c|}
\hline \multirow{2}{*}{$\begin{array}{l}\text { Divisão da Indústria } \\
\text { Segundo o Tipo de Indústria }\end{array}$} & \multirow{2}{*}{$\begin{array}{l}\text { GINI } \\
1997\end{array}$} & \multirow[b]{2}{*}{2007} & \multicolumn{2}{|l|}{ HHI } & \multicolumn{2}{|c|}{ CR(1) } & \multicolumn{2}{|c|}{ CR(5) } & \multicolumn{2}{|c|}{ CR(10) } & \multicolumn{2}{|c|}{ CR (25) } \\
\hline & & & 1997 & 2007 & 1997 & 2007 & 1997 & 2007 & 1997 & 2007 & 1997 & 2007 \\
\hline Extraçáo carvāo mineral & 0,96 & 0,94 & 0,29 & 0,37 & 49,0 & 60,1 & 89,3 & 81,1 & 95,4 & 87,9 & 99,6 & 95,6 \\
\hline Extração de petróleo e serviços relacionados & 0,95 & 0,95 & 0,15 & 0,21 & 25,1 & 38,1 & 75,7 & 80,6 & 92,9 & 91,9 & 99,6 & 99,4 \\
\hline Extraçăo de minerais metálicos & 0,92 & 0,92 & 0,25 & 0,20 & 48,8 & 41,4 & 66,3 & 67,9 & 80,8 & 81,6 & 95,8 & 95,5 \\
\hline Extração minerais não metálicos & 0,63 & 0,61 & 0,02 & 0,02 & 8,3 & 6,8 & 25,1 & 24,6 & 37,9 & 37,8 & 61,8 & 60,9 \\
\hline Fabricação de produtos do fumo & 0,92 & 0,92 & 0,12 & 0,16 & 24,6 & 33,2 & 69,8 & 73,4 & 87,1 & 83,9 & 96,1 & 96,4 \\
\hline Fabricação de celulose, papel e produtos de papel & 0,85 & 0,80 & 0,09 & 0,07 & 26,9 & 22,3 & 47,6 & 40,7 & 64,4 & 55,7 & 87,3 & 81,6 \\
\hline $\begin{array}{l}\text { Fabricação de coque, refino de petróleo, } \\
\text { elaboraçáo de combustível nuclear }\end{array}$ & 0,80 & 0,80 & 0,04 & 0,04 & 8,9 & 7,7 & 30,9 & 31,2 & 51,9 & 51,8 & 82,2 & 81,6 \\
\hline Fabricação de produtos químicos & 0,89 & 0,85 & 0,17 & 0,13 & 38,1 & 32,5 & 65,9 & 56,0 & 79,3 & 70,8 & 91,3 & 87,3 \\
\hline Fabricação de produtos de minerais não metálicos & 0,68 & 0,62 & 0,03 & 0,03 & 11,8 & 9,6 & 32,7 & 27,3 & 48,6 & 42,7 & 69,5 & 63,6 \\
\hline Metalurgia básica & 0,87 & 0,85 & 0,10 & 0,07 & 26,4 & 18,7 & 56,6 & 47,4 & 71,3 & 65,7 & 90,8 & 88,2 \\
\hline Reciclagem & 0,87 & 0,75 & 0,08 & 0,04 & 16,9 & 15,5 & 53,0 & 32,9 & 70,3 & 47,8 & 91,3 & 76,6 \\
\hline Subtotal Commodities & 0,73 & 0,68 & 0,07 & 0,05 & 21,8 & 16,9 & 42,9 & 36,1 & 55,5 & 47,8 & 73,9 & 68,7 \\
\hline Fabricação de máquinas e equipamentos & 0,89 & 0,84 & 0,12 & 0,07 & 30,9 & 22,0 & 55,0 & 44,1 & 74,9 & 65,0 & 93,1 & 87,3 \\
\hline $\begin{array}{l}\text { Fabricação de máquinas para escritório e } \\
\text { equipamentos de informática }\end{array}$ & 0,95 & 0,93 & 0,23 & 0,11 & 44,1 & 21,3 & 76,1 & 63,9 & 89,4 & 89,9 & 99,1 & 98,9 \\
\hline $\begin{array}{l}\text { Fabricação de máquinas, aparelhos e } \\
\text { materiais elétricos }\end{array}$ & 0,91 & 0,88 & 0,15 & 0,09 & 35,5 & 23,7 & 58,0 & 51,6 & 77,4 & 71,9 & 96,1 & 92,4 \\
\hline $\begin{array}{l}\text { Fabricação de material eletrônico, } \\
\text { de aparelhos e equipamento de computadores }\end{array}$ & 0,95 & 0,94 & 0,18 & 0,17 & 29,5 & 31,0 & 77,9 & 74,7 & 92,7 & 89,2 & 98,8 & 98,3 \\
\hline Fabricação de equipamentos de instrumentação & 0,91 & 0,89 & 0,16 & 0,11 & 36,2 & 28,3 & 64,1 & 54,8 & 80,7 & 74,9 & 95,5 & 93,1 \\
\hline Fabricaçáo de outros equipamentos de transporte & 0,91 & 0,92 & 0,13 & 0,12 & 22,2 & 22,2 & 74,2 & 71,7 & 84,2 & 84,5 & 95,1 & 95,8 \\
\hline $\begin{array}{l}\text { Fabricação e montagem de veículos automotores, } \\
\text { reboques e carrocerias }\end{array}$ & 0,93 & 0,90 & 0,23 & 0,12 & 45,2 & 29,6 & 74,3 & 61,3 & 87,5 & 81,5 & 95,9 & 95,0 \\
\hline Subtotal Difusora/Durável & 0,89 & 0,86 & 0,16 & 0,08 & 36,7 & 23,5 & 58,1 & 47,2 & 76,7 & 68,5 & 93,8 & 90,6 \\
\hline Fabricaçáo de produtos alimentícios e bebidas & 0,67 & 0,63 & 0,03 & 0,02 & 9,2 & 5,7 & 26,7 & 22,4 & 41,2 & 35,4 & 67,7 & 63,3 \\
\hline Fabricação de produtos têxteis & 0,83 & 0,82 & 0,07 & 0,06 & 18,5 & 14,4 & 48,3 & 47,8 & 63,7 & 63,2 & 85,2 & 84,3 \\
\hline Confecção de artigos do vestuário e acessórios & 0,81 & 0,78 & 0,07 & 0,05 & 20,5 & 15,4 & 45,6 & 40,0 & 59,8 & 54,8 & 82,9 & 80,2 \\
\hline $\begin{array}{l}\text { Preparação de couros e fabricação de } \\
\text { artefatos de couro e calçados }\end{array}$ & 0,88 & 0,83 & 0,17 & 0,10 & 39,1 & 27,7 & 60,2 & 47,7 & 73,5 & 65,5 & 90,9 & 86,2 \\
\hline Fabricação de produtos de madeira & 0,74 & 0,73 & 0,03 & 0,03 & 7,8 & 6,9 & 27,5 & 26,6 & 46,2 & 45,5 & 76,4 & 75,0 \\
\hline Edição, impressão e reprodução de gravaçóes & 0,85 & 0,81 & 0,16 & 0,12 & 35,9 & 31,1 & 61,8 & 55,1 & 71,3 & 65,4 & 85,7 & 82,2 \\
\hline Fabricação de artigos de borracha e plástico & 0,86 & 0,83 & 0,16 & 0,10 & 38,4 & 28,8 & 58,7 & 48,1 & 72,3 & 64,4 & 89,1 & 86,3 \\
\hline $\begin{array}{l}\text { Fabricaçáo de produtos de metal - } \\
\text { exclusive máquinas e equipamentos }\end{array}$ & 0,85 & 0,80 & 0,13 & 0,08 & 32,8 & 25,6 & 54,5 & 44,7 & 69,6 & 60,2 & 87,2 & 82,2 \\
\hline Fabricação de móveis e indústrias diversas & 0,78 & 0,75 & 0,06 & 0,04 & 19,2 & 13,0 & 40,2 & 35,0 & 57,5 & 52,8 & 79,6 & 77,1 \\
\hline Subtotal Tradicional & 0,71 & 0,66 & 0,05 & 0,03 & 18,0 & 13,2 & 36,2 & 28,1 & 48,5 & 40,8 & 72,0 & 65,9 \\
\hline Total. & 0,73 & 0,60 & $0,0 \underline{0}$ & $0,0,4$ & 22,0 & 15,8 & 41,4 & 32,3 & שִ & 45,0 & 74,0 & 68,7 \\
\hline
\end{tabular}

Fonte: RAIS 
Tabela 6 Índices de concentração espacial por divisão segundo os salários - 1997/2007

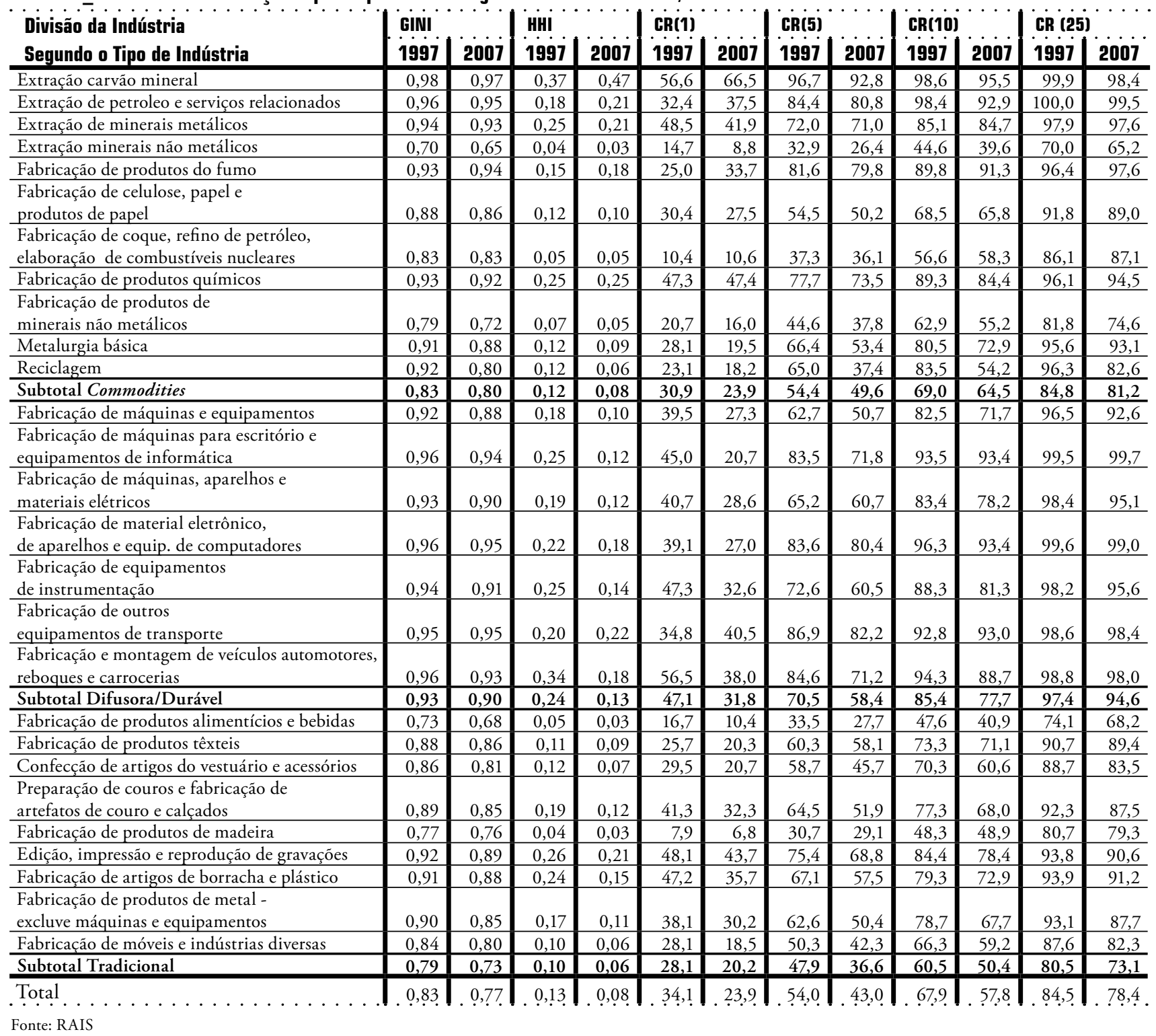




\section{Gráfico 3 _ĺndices de concentração espacial da indústria de commodities - 1997/2007}

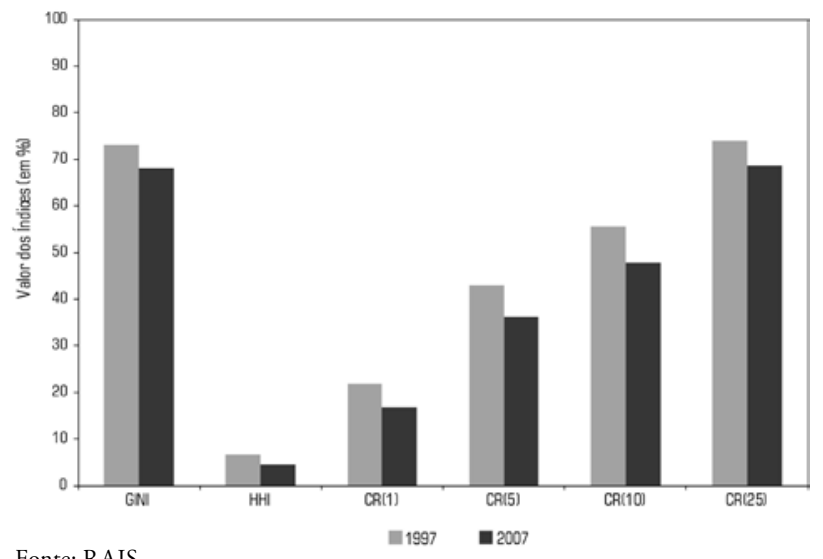

Fonte: RAIS

\section{Gráfico 5 _ Índices de concentração espacial da indústria tradicional - 1997/2007}

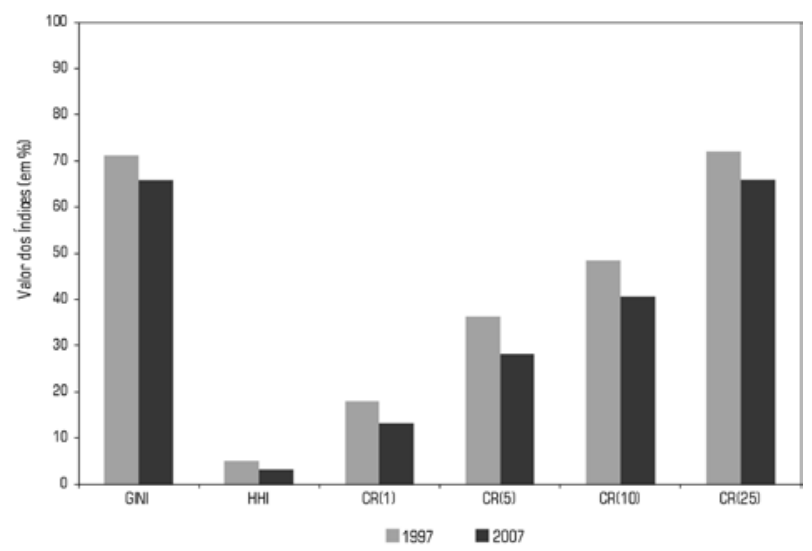

Fonte: RAIS

\footnotetext{
${ }^{11}$ No Anexo B, os dados da mesorregiôes são apresentados distribuiçáo do emprego segundo os seis grupos de para cada uma das 27 divisóes da indústria.
}

\section{Gráfico 4_Índices de concentração espacial da Indústria difusora/durável - 1997/2007}

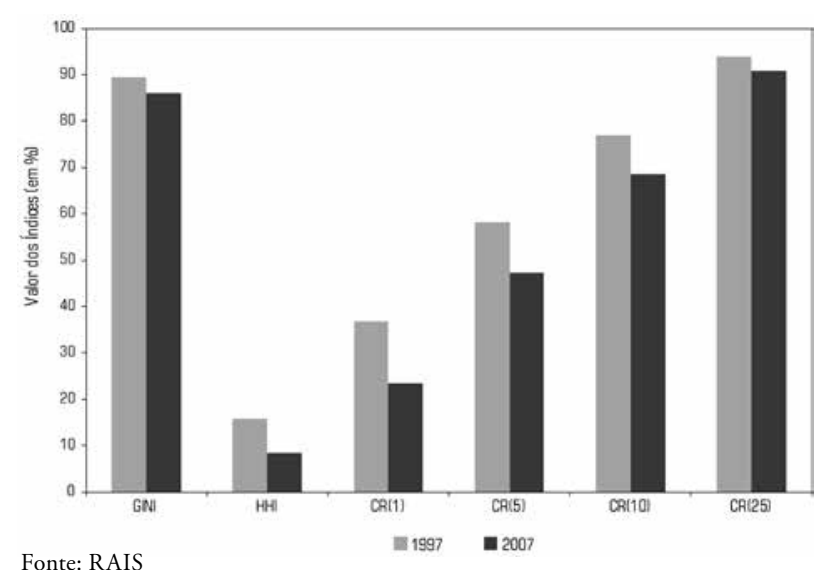

absorviam quase a mesma parcela do emprego das cinco principais. Da mesma forma que no caso das commodities, na indústria tradicional houve ganho mais expressivo para o terceiro grupo. Cabe ainda mencionar o peso ínfimo do emprego nos três últimos grupos de mesorregiôes quando consideradas a indústria difusora/durável, i.e. as de maior importância em termos de inovação e progresso técnico. ${ }^{11}$

A ser considerado o nível de concentração segundo a variável salarial nos três tipos de indústria, confirma-se a queda das cinco principais mesorregióes e o aumento nas demais. $\mathrm{O}$ grupo mais concentrado, i.e. difusora/durável, apresentou a maior queda entre as cinco mesor- 
regiōes, com redução de $70,5 \%$ para $57,4 \%$ dos salários, beneficiando, especialmente o segundo grupo, com aumento de quase 11 pontos percentuais. $\mathrm{Na}$ indústria tradicional, a perda do grupo principal se transforma em ganhos consideráveis para os demais. Movimento semelhante ocorre no segmento de commodities.

Os resultados desta seção são extremamente importantes, mostrando que não se trata apenas de um processo de desconcentração regional na indústria tradicional ou de commodities. Também na indústria difusora e de bens duráveis, o mesmo fenômeno da desconcentração regional se aplica, embora restrita a um menor número de mesorregióes. Portanto, a continuar tal tendência, o país poderia se tornar mais homogêneo em termos de desníveis regionais na indústria no longo prazo.

\section{A importância da indústria no interior das mesorregióes}

Uma vez apresentado o quadro das mudanças na distribuição do emprego e dos salários entre as mesorregióes, pode-se partir para a análise da importância do setor industrial em termos de atividade econômica no interior de cada mesorregiáo.

Usualmente, esse tipo de análise é feito utilizando-se a noção clássica de quociente locacional definido por:
Tabela 7 Distribuição do emprego por grupo de mesorregiões e tipo de indústria - 1997/2007

\begin{tabular}{|c|c|c|c|c|c|c|}
\hline \multirow{2}{*}{ Grupo } & \multicolumn{2}{|c|}{ Commodities } & \multicolumn{2}{|c|}{ Difusora/Durável } & \multicolumn{2}{|c|}{ Tradicional } \\
\hline & 1997 & 2007 & 1997 & 2007 & 1997 & 2007 \\
\hline 5 maiores & 42,9 & 36,1 & 58,1 & 47,2 & 36,2 & 28,1 \\
\hline 20 seguintes & 31,0 & 32,6 & 35,8 & 43,5 & 35,8 & 37,9 \\
\hline 25 seguintes & 14,3 & 17,1 & 4,8 & 6,8 & 16,1 & 19,2 \\
\hline 25 seguintes & 7,2 & 7,9 & 1,1 & 2,1 & 7,8 & 9,3 \\
\hline 25 seguintes & 3,5 & 4,5 & 0,3 & 0,4 & 3,0 & 4,0 \\
\hline 37 seguintes & 1,1 & 1,8 & 0,0 & 0,1 & 1,0 & 1,5 \\
\hline Total . . . . . & 100,0 & 100,0 & 100,0 & 100,0 & 100,0 & 100,0 \\
\hline
\end{tabular}

Tahela 8_Distribuição dos salários por grupo de mesorregióes e tipo de indústria - 1997/2007

\begin{tabular}{|c|c|c|c|c|c|c|}
\hline \multirow{2}{*}{ Grupo } & \multicolumn{2}{|c|}{ Commodities } & \multicolumn{2}{|c|}{ Difusora/Durável } & \multicolumn{2}{|c|}{ Iradicional . . } \\
\hline & 1997 & 2007 & 1997 & 2007 & 1997 & 2007 \\
\hline 5 maiores & 54,4 & 49,6 & 70,5 & 57,4 & 47,9 & 36,6 \\
\hline 20 seguintes & 30,4 & 31,6 & 26,9 & 37,4 & 32,7 & 36,5 \\
\hline 25 seguintes & 9,6 & 11,4 & 2,2 & 4,0 & 12,6 & 16,2 \\
\hline 25 seguintes & 4,0 & 4,8 & 0,3 & 1,0 & 4,7 & 6,9 \\
\hline 25 seguintes & 1,3 & 2,0 & 0,1 & 0,2 & 1,6 & 2,8 \\
\hline 37 seguintes & 0,3 & 0,7 & 0,0 & 0,0 & 0,5 & 1,0 \\
\hline Total & 100,0 & 100,0 & 100,0 & 100,0 & 100,0 & 100,0 \\
\hline
\end{tabular}

Fonte: RAIS

$$
\mathrm{Qij}=(\mathrm{Lij} / \mathrm{L} . \mathrm{j}) /(\mathrm{Li} . / \mathrm{L} . .)
$$

onde

Lij - emprego no setor i na mesorregião $\mathrm{j}$

L.j - emprego de todos os setores na mesorregiáo $\mathrm{j}$

Li. - emprego do setor i em todo o país

L.. - emprego de todos os setores em todo o país 
${ }^{12}$ Sobre essa questão, ver Crocco et al. (2006).

${ }^{13} \mathrm{O}$ nível de ocupação é uma das variáveis analisadas pela

Pesquisa Mensal de Emprego do IBGE.

${ }^{14}$ Normalmente, faz-se um corte etário inferior na população total para o cálculo da PIA. No Brasil, tal corte costuma ser de 10 anos ou 15 anos. Neste trabalho, utilizamos o corte etário de 15 anos na base e 69 anos no topo da pirâmide etária, eliminando os mais jovens e os mais idosos da PIA.
A utilização do quociente locacional aos dados da indústria levantados pela RAIS possui uma desvantagem. Conforme é sabido, o setor industrial tende a ser bem mais formalizado que os setores primário e terciário. Dessa forma, a cobertura da RAIS tende a ser bem melhor para a indústria do que para os demais setores. Portanto, o quociente locacional tende a superestimar o papel da indústria nas regióes mais atrasadas do país, onde o setor informal é grande, e subestimar naquelas mais desenvolvidas e diversificadas, onde o setor formal tem papel mais importante. ${ }^{12}$

Propóe-se neste artigo a utilizaçáo de um índice alternativo inspirado na noção clássica de nível de ocupação utilizada em estudos sobre o mercado de trabalho. ${ }^{13} \mathrm{O}$ nível de ocupação é obtido pelo quociente entre a população ocupada (PO) e a população em idade ativa (PIA). ${ }^{14}$ Quanto maior o valor do índice, maior é a proporção da população potencialmente voltada para o mercado de trabalho (PIA) efetivamente ocupada (PO).

$\mathrm{O}$ indice de densidade aqui proposto é construído com base na distribuição da população ocupada na indústria e na distribuição da população em idade ativa (PIA) nas mesorregióes.

Assim, o índice de densidade Dj da indústria na mesorregiáo j é dado por

$$
\mathrm{Dj}=(\mathrm{PO} j / \mathrm{PO}) /(\mathrm{PIAj} / \mathrm{PIA}),
$$

onde

POj - população ocupada na indústria

na mesorregião $\mathrm{j}$

PO - população ocupada na

indústria no país

PIAj - população em idade ativa

na mesorregião $j$

PIA - população em idade ativa no país

Se a distribuição da população ocupada na indústria for a mesma da PIA, todas as mesorregióes possuirão o mesmo índice de densidade unitário. Por outro lado, naquelas mesorregióes onde a participação do emprego industrial for maior do que a da PIA, o índice será superior à unidade e vice-versa quando a participação for menor. Assim, o índice de densidade mede a importância relativa do emprego industrial quando comparado à população potencial para o mercado de trabalho na mesorregião.

Ao se comparar o emprego industrial com a PIA, fica minimizado o problema apontado acima para o quociente locacional na medida em que não são utilizadas informações do emprego em outros setores da economia muito influenciados pelo nível de formalização de cada mesorregião. De qualquer forma, há que se reconhecer que o próprio emprego in- 
dustrial da RAIS sofre a influência do maior ou menor peso do setor informal na mesorregião, podendo reduzir o valor do índice naquelas onde ele é mais importante.

Uma crítica que poderia ser feita ao índice de densidade é o fato de que pessoas podem morar em uma mesorregião $\mathrm{e}$ trabalhar em outra. Como as mesorregióes brasileiras tendem a ser muito grandes, esse problema é relativamente pouco importante. Mas certamente deveria ser levado em consideração se a unidade geográfica fosse o município, e não a mesorregião (ou microrregião), não sendo aconselhada sua utilização nesse caso. ${ }^{15}$

A ideia desta seção é complementar o estudo do processo de desconcentração industrial combinando-se os índices clássicos de desigualdade/desconcentração apresentados na última seção com o índice de densidade industrial e o quociente locacional. Os primeiros fornecem um quadro geral do processo, ao passo que os segundos fornecem uma indicação da importância da indústria na atividade econômica da mesorregiáo.

Inicialmente são apresentadas as 25 mesorregióes com os maiores índices de densidade e os maiores quocientes locacionais em 1997 e 2007. Conforme pode ser verificado nas Tabelas 9a e 9b, os resultados encontrados com os dois índices apresentam semelhanças, tanto em termos de valor quanto das mesorregióes listadas nas duas tabelas. Considerando-se, por exemplo, o ano de 2007, 20 mesorregiões são comuns às duas formas de mensuração utilizadas. As principais ausências na Tabela 9b com os quocientes locacionais são as Regióes Metropolitanas de São Paulo, Porto Alegre e Curitiba, presentes entre as 25 mesorregióes com maiores índices de densidade na Tabela 9a. ${ }^{16}$ Cabe ainda notar que tanto o QL quanto o índice de densidade apontam para uma pequena tendência de crescimento no período nas 25 mesorregióes com os maiores indicadores.

Outras observações podem ser feitas em relação às diferenças de resultados encontrados com as duas metodologias. Tendo em vista a tendência de excluir as regióes metropolitanas entre aquelas com os maiores QLs, o volume de emprego industrial tende a ser menor nas mesorregióes selecionadas com os QLs mais elevados do que no caso dos maiores índices de densidade. Em 2007, por exemplo, as 25 mesorregióes com os maiores índices de densidade representavam 56\% do emprego industrial total, enquanto, no caso do QL, não chegavam a 36\%.

Um ponto que também merece ser apontado é o fato de a mesorregiáo de Marajó aparecer com o maior QL $(3,03)$ em 1997, em razão de o pequeno nível
${ }^{15}$ Conforme informado acima o índice de densidade está inspirado na noção clássica de nível de ocupação, utilizado pelo IBGE para a análise do mercado de trabalho para regióes metropolitanas, que usualmente correspondem a uma mesorregião.

${ }^{16}$ A RM de Porto Alegre está presente apenas em 1997 na Tabela $9 b$. 


\footnotetext{
${ }^{17}$ A divisão em quatro grupos é arbitrária, servindo para facilitar a análise. As tabelas com os dados dos quatro grupos apresentam as mesorregiōes ordenadas pelo valor do índice do mais baixo ao mais alto dentro de cada grupo. As tabelas com os dados dos Grupos Inferior e MédioInferior estão no Anexo C.
}

de emprego na indústria local ter grande peso no emprego total levantado pela RAIS, ilustrando a crítica apontada acima quanto ao uso do QL aos dados de emprego da RAIS. Tal fato se repetiu em menor escala em outras mesorregióes pouco desenvolvidas como o Sudoeste Mato-Grossense e o Leste Rondoniense, que definitivamente não se destacam pela importância da indústria local.

Para efeito de comparação entre os resultados obtidos com o QL e o índice de densidade, foram calculados os coeficientes de correlação entre os dois indicadores nas 137 mesorregióes do país, sendo encontrados os valores de $0,73 \mathrm{em}$ 1997, e 0,90 em 2007, confirmando haver certa semelhança em suas distribuiçóes, especialmente em 2007.

$\mathrm{Na}$ medida em que os resultados encontrados para o índice de densidade com base nas estatísticas da RAIS parecem ser mais coerentes que os obtidos com o QL, serão apresentados e discutidos no restante desta seção apenas aqueles obtidos com o primeiro indicador.

A seguir são mostrados os resultados de quatro grupos de mesorregióes classificados segundo o valor do índice de densidade industrial. ${ }^{17}$

O Grupo Superior, cujos índices de densidade igualam ou superam o valor 2, possui pequeno número de mesor- regióes com forte incidência de atividades industriais. Em 1997, era composto de apenas seis mesorregióes, aumentando para 11 em 2007 (Tabela 10). Tais mesorregióes estão localizadas em São Paulo, em Santa Catarina e no Rio Grande do Sul. Em 2007, havia ainda uma mesorregião do Paraná. Chama a atenção o fato de que Santa Catarina dobrou o número de mesorregióes no Grupo 4 no período, passando de duas em 1997 para quatro em 2007, i.e., o mesmo número encontrado em São Paulo. Cabe também mencionar que nem sempre as mesorregiōes desse grupo se caracterizam por grande volume de emprego industrial, mas sim pela importância que o emprego industrial tem em seu interior.

Cabe também acrescentar que em 2007 havia três mesorregióes - Nordeste Rio-Grandense, Norte Catarinense e Vale do Itajaí - com índices superiores a três, significando que tais regióes tinham participação no emprego industrial do país superior ao triplo de sua participação na PIA. Nos três casos, houve crescimento do índice no período, significando fortalecimento da indústria na atividade econômica dessas mesorregióes. As seis mesorregióes do Grupo Superior em 1997 permaneceram em seu interior em 2007.

O Grupo Médio-Superior, cujo índice de densidade varia de 1 e 2 (exclusive), 
Tabela 9_Empregos e população em idade ativa (PIA) nas mesorregiões com maiores índices de densidade - 1997/2007

(continua)

\begin{tabular}{|c|c|c|c|c|c|c|}
\hline UF & Mesorregião & PIA & $\%$ & Empregos & $\%$ & Índice \\
\hline SC & Norte Catarinense & 636.250 & 0,6 & 94.000 & 2,0 & 3,22 \\
\hline SC & Vale do Itajaí & 729.578 & 0,7 & 95.806 & 2,0 & 2,86 \\
\hline RS & Nordeste Rio-Grandense & 807.343 & 0,8 & 94.894 & 2,0 & 2,56 \\
\hline SP & Piracicaba & 781.097 & 0,8 & 86.184 & 1,8 & 2,41 \\
\hline SP & Macro Metropolitana Paulista & 1.363 .628 & 1,3 & 139.994 & 2,9 & 2,24 \\
\hline SP & Campinas & 2.098 .329 & 2,0 & 200.990 & 4,2 & 2,09 \\
\hline $\mathrm{RS}$ & Metropolitana de Porto Alegre & 2.854 .396 & 2,7 & 245.855 & 5,2 & 1,88 \\
\hline SP & Araraquara & 464.965 & 0,4 & 39.678 & 0,8 & 1,86 \\
\hline SP & Metropolitana de São Paulo & 12.464 .183 & 12,0 & 1.049 .531 & 22,0 & 1,84 \\
\hline SC & Sul Catarinense & 511.692 & 0,5 & 42.900 & 0,9 & 1,83 \\
\hline SC & Oeste Catarinense & 711.365 & 0,7 & 59.209 & 1,2 & 1,82 \\
\hline PR & Metropolitana de Curitiba & 1.674 .388 & 1,6 & 122.788 & 2,6 & 1,60 \\
\hline SP & Vale do Paraíba Paulista & 1.227 .148 & 1,2 & 86.523 & 1,8 & 1,54 \\
\hline SP & Bauru & 838.499 & 0,8 & 58.079 & 1,2 & 1,51 \\
\hline RJ & Centro Fluminense & 299.309 & 0,3 & 20.334 & 0,4 & 1,48 \\
\hline MG & Oeste de Minas & 544.779 & 0,5 & 36.105 & 0,8 & 1,45 \\
\hline SP & Marília & 268.102 & 0,3 & 17.475 & 0,4 & 1,42 \\
\hline SP & Araçatuba & 426.616 & 0,4 & 27.750 & 0,6 & 1,42 \\
\hline PR & Norte Central Paranaense & 1.184 .297 & 1,1 & 74.440 & 1,6 & 1,37 \\
\hline PE & Mata Pernambucana & 698.467 & 0,7 & 43.706 & 0,9 & 1,36 \\
\hline MG & Metropolitana de Belo Horizonte & 3.486 .636 & 3,4 & 215.659 & 4,5 & 1,35 \\
\hline PR & Sudeste Paranaense & 234.884 & 0,2 & 14.052 & 0,3 & 1,30 \\
\hline SC & Serrana & 242.269 & 0,2 & 14.434 & 0,3 & 1,30 \\
\hline SP & Ribeirão Preto & 1.354 .060 & 1,3 & 78.834 & 1,7 & 1,27 \\
\hline AL & Leste Alagoano & 1.060 .165 & 1,0 & 61.271 & 1,3 & 1,26 \\
\hline \multicolumn{2}{|c|}{ Subtotal } & 36.962 .445 & 35,53 & 3.020 .491 & 63,32 & 1,78 \\
\hline \multicolumn{2}{|c|}{ Total } & 104.029 .189 & 100,0 & 4.769 .855 & 100,0 & 1,00 \\
\hline
\end{tabular}


Tabela 9_Empregos e população em idade ativa (PIA) nas mesorregióes com maiores índices de densidade - 1997/2007

(conclusão)

\begin{tabular}{|c|c|c|c|c|c|c|}
\hline UF & Mesorregião & PIA & $\%$ & Empregos & $\%$ & Índice \\
\hline RS & Nordeste Rio-Grandense & 762.436 & 0,6 & 148.876 & 2,1 & 3,59 \\
\hline SC & Norte Catarinense & 846.073 & 0,6 & 154.862 & 2,2 & 3,36 \\
\hline SC & Vale do Itajaí & 1.006 .205 & 0,8 & 176.264 & 2,5 & 3,22 \\
\hline SP & Piracicaba & 1.005 .094 & 0,8 & 145.784 & 2,1 & 2,67 \\
\hline SC & Oeste Catarinense & 827.972 & 0,6 & 108.813 & 1,5 & 2,42 \\
\hline PR & Noroeste Paranaense & 444.301 & 0,3 & 56.025 & 0,8 & 2,32 \\
\hline SC & Sul Catarinense & 660.376 & 0,5 & 77.586 & 1,1 & 2,16 \\
\hline SP & Macro Metropolitana Paulista & 1.891 .340 & 1,5 & 217.949 & 3,1 & 2,12 \\
\hline RS & Centro Oriental Rio-Grandense & 570.420 & 0,4 & 63.280 & 0,9 & 2,04 \\
\hline SP & Campinas & 2.743 .043 & 2,1 & 302.869 & 4,3 & 2,03 \\
\hline SP & Araraquara & 589.704 & 0,5 & 64.597 & 0,9 & 2,01 \\
\hline MG & Oeste de Minas & 669.937 & 0,5 & 69.334 & 1,0 & 1,90 \\
\hline SP & Araçatuba & 499.405 & 0,4 & 49.025 & 0,7 & 1,80 \\
\hline PR & Norte Central Paranaense & 1.432 .908 & 1,1 & 136.126 & 1,9 & 1,75 \\
\hline SP & Ribeirão Preto & 1.689 .497 & 1,3 & 156.051 & 2,2 & 1,70 \\
\hline PR & Metropolitana de Curitiba & 2.133 .024 & 1,6 & 195.522 & 2,8 & 1,68 \\
\hline SP & Bauru & 1.048 .533 & 0,8 & 93.985 & 1,3 & 1,65 \\
\hline RS & Metropolitana de Porto Alegre & 3.537 .176 & 2,7 & 315.653 & 4,4 & 1,64 \\
\hline PR & Sudoeste Paranaense & 328.706 & 0,3 & 26.832 & 0,4 & 1,50 \\
\hline RJ & Centro Fluminense & 338.666 & 0,3 & 27.568 & 0,4 & 1,50 \\
\hline PR & Centro Oriental Paranaense & 468.422 & 0,4 & 36.073 & 0,5 & 1,42 \\
\hline SP & Vale do Paraíba Paulista & 1.631 .336 & 1,3 & 123.843 & 1,7 & 1,40 \\
\hline $\mathrm{AL}$ & Leste Alagoano & 1.313 .076 & 1,0 & 98.137 & 1,4 & 1,37 \\
\hline SP & Metropolitana de São Paulo & 15.297 .808 & 11,7 & 1.121 .561 & 15,8 & 1,35 \\
\hline PR & Oeste Paranaense & 877.227 & 0,7 & 64.188 & 0,9 & 1,34 \\
\hline \multicolumn{2}{|c|}{ Subtotal } & 42.612 .685 & 30,75 & 4.030 .803 & 55,99 & 1,82 \\
\hline \multicolumn{2}{|c|}{ Total } & 138.585.657 & 100,0 & 7.093.368 & 100,0 & 1,00 \\
\hline
\end{tabular}

Fonte: DataSUS e RAIS 
Tabela 9a_Emprego industrial e total nas mesorregiões com maiores quocientes locacionais (QL)

(continua)

\begin{tabular}{|c|c|c|c|c|c|c|}
\hline UF & Mesorregião & $\begin{array}{l}\text { Emprego } \\
\text { Industrial }\end{array}$ & $\%$ & Emprego & $\%$ & QL \\
\hline PA & Marajó & 3.971 & 0,1 & 6.575 & 0,0 & 3,05 \\
\hline SC & Norte Catarinense & 94.000 & 2,0 & 189.847 & 0,8 & 2,50 \\
\hline RS & Nordeste Rio-Grandense & 94.894 & 2,0 & 194.890 & 0,8 & 2,46 \\
\hline RS & Centro Oriental Rio-Grandense & 46.381 & 1,0 & 109.670 & 0,5 & 2,13 \\
\hline SC & Vale do Itajaí & 95.806 & 2,0 & 226.730 & 0,9 & 2,13 \\
\hline PR & Sudeste Paranaense & 14.052 & 0,3 & 33.637 & 0,1 & 2,11 \\
\hline PE & Mata Pernambucana & 43.706 & 0,9 & 106.139 & 0,4 & 2,08 \\
\hline MT & Norte Mato-Grossense & 18.249 & 0,4 & 46.430 & 0,2 & 1,98 \\
\hline SC & Sul Catarinense & 42.900 & 0,9 & 109.591 & 0,5 & 1,98 \\
\hline SC & Oeste Catarinense & 59.209 & 1,2 & 152.748 & 0,6 & 1,96 \\
\hline SP & Piracicaba & 86.184 & 1,8 & 226.543 & 0,9 & 1,92 \\
\hline PA & Sudeste Paraense & 14.498 & 0,3 & 39.329 & 0,2 & 1,86 \\
\hline MT & Sudoeste Mato-Grossense & 7.372 & 0,2 & 20.106 & 0,1 & 1,85 \\
\hline SP & Macro Metropolitana Paulista & 139.994 & 2,9 & 399.182 & 1,7 & 1,77 \\
\hline MG & Oeste de Minas & 36.105 & 0,8 & 103.584 & 0,4 & 1,76 \\
\hline PR & Noroeste Paranaense & 22.696 & 0,5 & 69.561 & 0,3 & 1,65 \\
\hline SP & Campinas & 200.990 & 4,2 & 619.649 & 2,6 & 1,64 \\
\hline $\mathrm{RO}$ & Leste Rondoniense & 14.436 & 0,3 & 48.241 & 0,2 & 1,51 \\
\hline SP & Araraquara & 39.678 & 0,8 & 133.651 & 0,6 & 1,50 \\
\hline AL & Leste Alagoano & 61.271 & 1,3 & 207.775 & 0,9 & 1,49 \\
\hline SP & Vale do Paraíba Paulista & 86.523 & 1,8 & 294.397 & 1,2 & 1,48 \\
\hline PR & Sudoeste Paranaense & 13.173 & 0,3 & 45.027 & 0,2 & 1,48 \\
\hline RS & Metropolitana de Porto Alegre & 245.855 & 5,2 & 842.692 & 3,5 & 1,47 \\
\hline RJ & Centro Fluminense & 20.334 & 0,4 & 70.113 & 0,3 & 1,46 \\
\hline SP & Araçatuba & 27.750 & 0,6 & 96.343 & 0,4 & 1,45 \\
\hline \multicolumn{2}{|c|}{ Subtotal } & 1.530 .027 & 32,1 & 4.392 .450 & 18,2 & 1,76 \\
\hline \multicolumn{2}{|c|}{ Total } & 4.769 .855 & 100,0 . & 24.078.389 & 100,0 . & 1,00 \\
\hline
\end{tabular}


Tabela 9a_Emprego industrial e total nas mesorregióes com maiores quocientes locacionais (QL)

\begin{tabular}{|c|c|c|c|c|c|c|}
\hline UF & Mesorregião & $\begin{array}{l}\text { Emprego } \\
\text { Industrial }\end{array}$ & $\%$ & Emprego & $\%$ & $\mathbf{Q L}$ \\
\hline RS & Nordeste Rio-Grandense & 148.876 & 2,1 & 306.626 & 0,8 & 2,57 \\
\hline SC & Norte Catarinense & 154.862 & 2,2 & 328.390 & 0,9 & 2,50 \\
\hline PR & Noroeste Paranaense & 56.025 & 0,8 & 131.398 & 0,3 & 2,26 \\
\hline SC & Vale do Itajaí & 176.264 & 2,5 & 431.657 & 1,1 & 2,16 \\
\hline RS & Centro Oriental Rio-Grandense & 63.280 & 0,9 & 156.704 & 0,4 & 2,14 \\
\hline SP & Piracicaba & 145.784 & 2,1 & 375.621 & 1,0 & 2,06 \\
\hline PE & Mata Pernambucana & 59.821 & 0,8 & 155.250 & 0,4 & 2,04 \\
\hline SC & Sul Catarinense & 77.586 & 1,1 & 204.639 & 0,5 & 2,01 \\
\hline SC & Oeste Catarinense & 108.813 & 1,5 & 289.980 & 0,8 & 1,99 \\
\hline MG & Oeste de Minas & 69.334 & 1,0 & 190.865 & 0,5 & 1,93 \\
\hline SP & Macro Metropolitana Paulista & 217.949 & 3,1 & 621.973 & 1,7 & 1,86 \\
\hline PR & Sudeste Paranaense & 17.564 & 0,2 & 52.574 & 0,1 & 1,77 \\
\hline SP & Araçatuba & 49.025 & 0,7 & 148.052 & 0,4 & 1,76 \\
\hline PR & Sudoeste Paranaense & 26.832 & 0,4 & 83.204 & 0,2 & 1,71 \\
\hline ES & Noroeste Espírito-Santense & 19.773 & 0,3 & 64.556 & 0,2 & 1,62 \\
\hline SP & Campinas & 302.869 & 4,3 & 996.986 & 2,7 & 1,61 \\
\hline SP & Araraquara & 64.597 & 0,9 & 214.661 & 0,6 & 1,60 \\
\hline PR & Norte Central Paranaense & 136.126 & 1,9 & 456.148 & 1,2 & 1,58 \\
\hline AL & Leste Alagoano & 98.137 & 1,4 & 346.866 & 0,9 & 1,50 \\
\hline MG & Sul/Sudoeste de Minas & 123.702 & 1,7 & 441.743 & 1,2 & 1,48 \\
\hline SP & Ribeirão Preto & 156.051 & 2,2 & 560.233 & 1,5 & 1,48 \\
\hline PR & Norte Pioneiro Paranaense & 24.125 & 0,3 & 88.428 & 0,2 & 1,45 \\
\hline RJ & Centro Fluminense & 27.568 & 0,4 & 101.579 & 0,3 & 1,44 \\
\hline SP & Bauru & 93.985 & 1,3 & 352.133 & 0,9 & 1,42 \\
\hline SP & Vale do Paraíba Paulista & 123.843 & 1,7 & 465.745 & 1,2 & 1,41 \\
\hline \multicolumn{2}{|c|}{ Subtotal } & 2.542 .791 & 35,8 & 7.566 .011 & 20,1 & 1,78 \\
\hline \multicolumn{2}{|l|}{ Total. } & 7.093.368 & 100,0 . & 37.607 .426 & 100,0 . & 1,00 \\
\hline
\end{tabular}

Fonte: RAIS 
estando, portanto, acima da média nacional, cresceu bastante no período, passando de 28 para 38 mesorregióes. Houve, portanto, forte migração dos grupos inferiores para o Médio-Superior. Conforme a Tabela 11, ele incorporava em 2007 algumas mesorregióes industriais do Sul/ Sudeste bastante importantes em termos econômicos como as Regiōes Metropolitanas de São Paulo, Porto Alegre, Curitiba e Belo Horizonte. Inclui ainda a Regiáo Metropolitana de Fortaleza. $\mathrm{Na}$ região Norte, a mesorregião Centro Amazonense, onde Manaus está localizada, e a Sudoeste Mato-Grossense e Norte Mato-Grossense pertencem a esse grupo. Da região Nordeste fazem parte também do Grupo Médio-Superior o Leste Alagoano e a Mata Pernambucana, regióes que concentram boa parte do complexo sucroalcooleiro. Destacam-se ainda o Sul Goiano e o Leste do Mato Grosso do Sul nesse grupo, confirmando a atração exercida pela região Centro-Oeste nos últimos anos para alguns segmentos da indústria. A mesorregião do Sul Goiano, por exemplo, possuía índice de densidade 0,47 em 1997, subindo para 1,15 dez anos depois. No caso do Leste do Mato Grosso do Sul, o crescimento foi de 0,59 para 1,30.

A perda de importância relativa da Região Metropolitana de São Paulo no período quando considerado o índice de
Tabela 10_Índice de densidade por mesorregião - grupo superior" - 1997/2007

\begin{tabular}{|c|c|c|c|c|c|}
\hline & 1997 & & & 2007 & \\
\hline UF & Mesorregião & Índice & UF & Mesorregião & Índice \\
\hline SC & Norte Catarinense & 3,22 & RS & Nordeste Rio-Grandense & 3,59 \\
\hline SC & Vale do Itajaí & 2,86 & SC & Norte Catarinense & 3,36 \\
\hline RS & Nordeste Rio-Grandense & 2,56 & SC & Vale do Itajaí & 3,22 \\
\hline SP & Piracicaba & 2,41 & SP & Piracicaba & 2,67 \\
\hline SP & Macro Metropolitana Paulista & 2,24 & SC & Oeste Catarinense & 2,42 \\
\hline SP & Campinas & 2,09 & PR & Noroeste Paranaense & 2,32 \\
\hline & & & SC & Sul Catarinense & 2,16 \\
\hline & & & SP & $\begin{array}{r}\text { Macro Metropolitana } \\
\text { Paulista }\end{array}$ & 2,12 \\
\hline & & & RS & $\begin{array}{l}\text { Centro Oriental } \\
\text { Rio-Grandense }\end{array}$ & 2,04 \\
\hline & & & SP & Campinas & 2,03 \\
\hline & & & SP & Araraquara & 2,01 \\
\hline
\end{tabular}

Fonte: RAIS

$\left({ }^{*}\right)$ Valor do índice igual ou superior a 2

densidade é notória. Em 1997, era uma das que possuíam o valor mais elevado do Grupo Médio-Superior (1,84). Em 2007, entretanto, havia baixado para 1,35. Isso não significa que a Região Metropolitana de Sáo Paulo esteja passando por um processo de desindustrialização e de perda da centralidade na indústria brasileira. Provavelmente, o que estaria ocorrendo é a substituição de plantas industriais localizadas na regiâo por atividades na prestação de serviços modernos de apoio à indústria não contabilizadas nos dados da indústria propriamente dita. 
Tabela 11_Índice de densidade por mesorregião - grupo médio superior* - 1997/2007

\begin{tabular}{|c|c|c|c|c|c|}
\hline & 1997 & & & 007 & \\
\hline UF & Mesorregião & Índice & UF & Mesorregião & Índice \\
\hline RS & Metropolitana de Porto Alegre & 1,88 & $\overline{M G}$ & Oeste de Minas & 1,90 \\
\hline SP & Araraquara & 1,86 & SP & Araçatuba & 1,80 \\
\hline SP & Metropolitana de São Paulo & 1,84 & PR & Norte Central Paranaense & 1,75 \\
\hline SC & Sul Catarinense & 1,83 & SP & Ribeirão Preto & 1,70 \\
\hline SC & Oeste Catarinense & 1,82 & PR & Metropolitana de Curitiba & 1,68 \\
\hline $\mathrm{PR}$ & Metropolitana de Curitiba & 1,60 & SP & Bauru & 1,65 \\
\hline SP & Vale do Paraíba Paulista & 1,54 & RS & Metropolitana de Porto Alegre & 1,64 \\
\hline SP & Bauru & 1,51 & PR & Sudoeste Paranaense & 1,50 \\
\hline RJ & Centro Fluminense & 1,48 & $\mathrm{RJ}$ & Centro Fluminense & 1,50 \\
\hline MG & Oeste de Minas & 1,45 & $\mathrm{PR}$ & Centro Oriental Paranaense & 1,42 \\
\hline SP & Marília & 1,42 & SP & Vale do Paraíba Paulista & 1,40 \\
\hline SP & Araçatuba & 1,42 & $\mathrm{AL}$ & Leste Alagoano & 1,37 \\
\hline PR & Norte Central Paranaense & 1,37 & $\mathrm{SP}$ & Metropolitana de São Paulo & 1,35 \\
\hline $\mathrm{PE}$ & Mata Pernambucana & 1,36 & PR & Oeste Paranaense & 1,34 \\
\hline $\mathrm{MG}$ & Metropolitana de Belo Horizonte & 1,35 & $\mathrm{RJ}$ & Norte Fluminense & 1,31 \\
\hline $\mathrm{PR}$ & Sudeste Paranaense & 1,30 & PE & Mata Pernambucana & 1,31 \\
\hline SC & Serrana & 1,30 & SP & Marília & 1,30 \\
\hline SP & Ribeirão Preto & 1,27 & MS & Leste de Mato Grosso do Sul & 1,30 \\
\hline $\mathrm{AL}$ & $\begin{array}{l}\text { Leste Alagoano } \\
\end{array}$ & 1,26 & MG & Sul/Sudoeste de Minas & 1,29 \\
\hline PR & Centro Ocidental Paranaense & 1,25 & ES & Noroeste Espírito-Santense & 1,28 \\
\hline $\mathrm{PR}$ & Noroeste Paranaense & 1,19 & SP & Sáo José do Rio Preto & 1,27 \\
\hline SP & Itapetininga & 1,18 & SP & Itapetininga & 1,20 \\
\hline RJ & Sul Fluminense & 1,15 & SP & Presidente Prudente & 1,19 \\
\hline $\mathrm{CE}$ & Metropolitana de Fortaleza & 1,12 & $\mathrm{PR}$ & Sudeste Paranaense & 1,19 \\
\hline MG & Sul/Sudoeste de Minas & 1,07 & PR & Norte Pioneiro Paranaense & 1,17 \\
\hline AM & Centro Amazonense & 1,05 & AM & Centro Amazonense & 1,15 \\
\hline SP & Sáo José do Rio Preto & 1,02 & $\mathrm{GO}$ & Sul Goiano & 1,15 \\
\hline MT & Norte Mato-Grossense & 1,01 & MT & Sudoeste Mato-Grossense & 1,15 \\
\hline & & & SC & Serrana & 1,15 \\
\hline & & & RJ & $\begin{array}{r}\text { Sul Fluminense } \\
\end{array}$ & 1,14 \\
\hline & & & MG & Metropolitana de Belo Horizonte & 1,14 \\
\hline & & & MT & Norte Mato-Grossense & 1,07 \\
\hline & & & $\mathrm{CE}$ & Metropolitana de Fortaleza & 1,07 \\
\hline & & & SP & Assis & 1,05 \\
\hline & & & RS & Noroeste Rio-Grandense & 1,05 \\
\hline & & & MG & Triângulo Mineiro/Alto Paranaíba & 1,03 \\
\hline & & & ES & Litoral Norte Espírito-Santense & 1,03 \\
\hline & & & MG & . . . . . . . Central Mineira & 1,03 \\
\hline
\end{tabular}


O Grupo Médio-Inferior possui índices de densidade na faixa de 0,5 a 1 (exclusive), estando, portanto, abaixo da média nacional. Ele era composto de 35 mesorregióes em 1997 e de 21 em 2007. Predominam aí algumas mesorregióes relativamente menos industrializadas dos estados das regióes Sul e Sudeste e outras mais industrializadas das regióes Norte, Nordeste e Centro-Oeste. Fazem parte desse grupo as Regióes Metropolitanas do Rio de Janeiro, de Salvador e do Recife. ${ }^{18}$

O Grupo Inferior, é composto das mesorregióes com índice de densidade abaixo de 0,5, significando que a indústria tem peso relativo muito pequeno na atividade econômica local. Em 1997, esse grupo era composto de 68 mesorregióes, baixando para 57 em 2007. Tais mesorregiôes usualmente estão localizadas nos estados das regióes Norte, Nordeste e Centro-Oeste. São relativamente raros os casos de mesorregióes localizadas em estados das regióes Sul e Sudeste (apenas sete casos em 2007), como no Norte de Minas Gerais, no litoral de São Paulo e Rio de Janeiro e no interior do Rio Grande Sul. Esse grupo inclui ainda o Distrito Federal e uma única Região Metropolitana (Belém) nos dois anos analisados.

$\mathrm{O}$ fato de o número de mesorregióes destes dois últimos grupos ter baixado no período aponta claramente no sentido
Tabela 12_Número de mesorregióes segundo o índice de densidade - 1997/2007

\begin{tabular}{|c|c|c|c|}
\hline Grupo & Descrição & $\begin{array}{l}N^{0} \text { de Mesorregióes } \\
1997\end{array}$ & 2007 \\
\hline Inferior & Índice $<0,5$ & 68 & 57 \\
\hline Médio Inferior & Índice de 0,5 a menos de 1 & 35 & 31 \\
\hline Médio Superior & Índice de 1 a menos de 2 & 28 & 38 \\
\hline Superior & Índice $>2$ & 6 & 11 \\
\hline & Total & 137 & 137 \\
\hline
\end{tabular}

Fonte: RAIS

de maior atração do emprego industrial para algumas mesorregióes menos industrializadas do país no período, confirmando a tendência à desconcentração da indústria já apontada na seção anterior.

A redução da importância das regióes metropolitanas em particular e das mesorregióes das capitais em geral nos indicadores de densidade industrial no período confirmam a tendência apontada em Senai (2005) no sentido da migração do emprego tipicamente industrial das capitais para o interior do país.

Os dados apresentados acima mostram o aumento da importância das mesorregiōes da regiáo Sul no período considerado, favorecendo o argumento de que a região Sul teria sido no passado recente e continuaria no presente sendo a grande beneficiária do processo de desconcentração industrial que vem ocorrendo no Brasil. ${ }^{19}$

A Tabela 12 apresenta de forma agregada a distribuição das 137 mesorregióes se-

\footnotetext{
${ }^{18}$ As tabelas dos Grupos Médio-Inferior e Inferior estão apresentadas no Anexo 3.

${ }^{19}$ Ver, por exemplo, Azevedo e Toneto Júnior (2001) e Saboia (2001), que apontam para a mesma tendência na década de noventa.
} 
gundo os quatro grupos de índices de densidade considerados em 1997 e 2007

Em resumo, o principal resultado mostrado pelos índices de densidade utilizados nesta seção é o aumento da importância da indústria na atividade econômica (através da variável emprego) nas mesorregióes da regiáo Sul e a queda relativa das regiōes metropolitanas. Além disso, houve migração de grande número de mesorregiōes onde a atividade industrial é relativamente reduzida para níveis mais elevados do índice de densidade, significando aumento da importância da indústria naquelas mesorregiôes do interior do país, corroborando o processo de desconcentração regional da indústria no período.

\section{5_Exemplos de mesorregiões que se destacaram no período}

Nesta seção serão selecionados alguns casos de mesorregióes que apresentam valores elevados para o índice de densidade ou que passaram por forte crescimento do emprego industrial no período. Tais mesorregióes mostram a diversidade e a complexidade do fenômeno no Brasil.

Em primeiro lugar, são analisadas as três mesorregióes com os maiores valores para o índice de densidade, superior a três em 2007, localizadas na região Sul do país.
Em segundo lugar, foram selecionadas cinco mesorregiōes em cinco estados distintos, que passaram por grande crescimento do nível de emprego nos últimos anos, ilustrando o processo de desconcentração industrial no período analisado.

\section{1_As três mesorregióes com os maiores índices de densidade industrial}

Será analisada brevemente nesta seção a estrutura da indústria nas três mesorregióes que se destacaram em termos do índice de densidade conforme discussão da seçâo anterior. Trata-se do Nordeste Rio-Grandense, do Norte Catarinense e do Vale do Itajaí. A primeira está localizada no Rio Grande do Sul, e as duas outras, em Santa Catarina. Nos três casos, o índice encontrado em 2007 era superior ao valor três, significando que, proporcionalmente à sua população em idade ativa, há três vezes mais empregos industriais do que na média do país. Além disso, o índice de densidade das três mesorregióes cresceu no período analisado, mostrando a força $\mathrm{da}$ indústria em tais mesorregióes. $\mathrm{O}$ volume de emprego industrial nas três mesorregióes em 2007 era de quase 500 mil.

A mesorregiáo Nordeste Rio-Grandense possui 53 municípios e três microrregiōes (Caxias do Sul, Guaporé e Vacaria). O Norte Catarinense compreende 26 municípios e três microrregióes (Joinville, 
Canoinhas e São Bento do Sul). Já a mesorregião do Vale do Itajaí possui $54 \mathrm{mu}$ nicípios e quatro microrregióes (Blumenau, Itajaí, Rio do Sul e Ituporanga). ${ }^{21}$

No período considerado, o volume de emprego aumentou 56,9\% no Nordeste Rio-Grandense, $64,7 \%$ no Norte Catarinense e $84,0 \%$ no Vale do Itajaí, i.e., bem acima do crescimento do emprego industrial de $48,7 \%$ verificado no país. Daí a razão para o aumento do índice de densidade nas três mesorregióes.

Cada uma delas possui características distintas das demais. O destaque no Norte Catarinense é a importância da indústria difusora/durável, representando mais de $26 \%$ do emprego da mesorregião, ou seja, bem mais do que a taxa média do país. Duas divisóes se destacam em seu interior - Fabricação de Máquinas e Equipamentos e Fabricação de Máquinas, Aparelhos e Materiais Elétricos. A primeira representava $14 \%$ do emprego industrial local, e a segunda, 7\% em 2007 (Tabela 13).

Uma das características do Nordeste Rio-Grandense é a elevada participação do emprego na Fabricação e na Montagem de Veículos Automotores, Reboques e Carrocerias, apresentando tendência de crescimento relativo no período. Em 2007, 17,3\% do emprego da mesorregião localizava-se nessa divisão da indús- tria, representando mais que o triplo da taxa média do país. Sua participação no emprego da indústria difusora/durável é relativamente alta quando comparada com a média nacional, apontando para a relativa sofisticação de sua indústria. Em contrapartida, possui baixa importância no segmento de commodities. Assim como nas duas outras mesorregióes analisadas nesta seção, a principal atividade industrial do Nordeste Rio-Grandense em termos de emprego continua sendo a indústria tradicional.

No caso do Vale do Itajaí, sua maior característica é a elevada participação na Fabricação de Produtos Têxteis, Confecção de Artigos de Vestuário e Assessórios. Mais da metade do emprego industrial da mesorregião está localizada nessas duas divisôes da indústria tradicional. Sua participação no emprego nas indústrias de commodities e difusora/durável é bem inferior à média do país.

$\mathrm{Na}$ Tabela 14 são apresentados os dados da distribuição dos salários por divisão da indústria nas três mesorregióes selecionadas. Tendo em vista o maior nível de produtividade nas indústrias difusoras/duráveis, sua participação nos salários é mais elevada que no emprego, ao mesmo tempo em que se reduz a peso dos salários na indústria tradicional comparativamente ao emprego.

\footnotetext{
${ }^{20}$ A lista completa de microrregiōes e municípios das mesorregiốes discutidas na seção 5 está apresentada no Anexo D.
} 
Tabela 13_Distribuição do emprego por divisão e tipo de indústria - mesorregióes selecionadas da região sul - 1997/2007

\begin{tabular}{|c|c|c|c|c|c|c|c|c|}
\hline \multirow[t]{2}{*}{ Divisão da Indústria Segundo o Tipo de Indústria } & \multicolumn{2}{|c|}{$\begin{array}{l}\text { Nordeste } \\
\text { Rio-Grandense }\end{array}$} & \multicolumn{2}{|c|}{ Norte Catarinense } & \multicolumn{2}{|c|}{ Vale do Itajaí } & \\
\hline & 1997 & 2007 & 1997 & 2007 & 1997 & 2007 & 1997 & 2007 \\
\hline Extração carvão mineral & 0,0 & 0,0 & 0,0 & 0,0 & 0,0 & 0,0 & 0,1 & 0,1 \\
\hline Extraçáo de petroleo e serviços relacionados & 0,0 & 0,0 & 0,0 & 0,1 & 0,1 & 0,1 & 0,2 & 0,7 \\
\hline Extraçáo de minerais metálicos & 0,0 & 0,0 & 0,0 & 0,0 & 0,0 & 0,0 & 0,6 & 0,7 \\
\hline Extração minerais não metálicos & 0,7 & 0,7 & 0,3 & 0,4 & 0,6 & 0,4 & 1,4 & 1,1 \\
\hline Fabricação de produtos do fumo & 0,0 & 0,0 & 0,0 & 0,1 & 0,3 & 0,2 & 0,4 & 0,2 \\
\hline Fabricação de celulose, papel e produtos de papel & 1,5 & 1,8 & 2,8 & 2,4 & 2,0 & 2,4 & 2,5 & 2,2 \\
\hline Fabriação de coque, refino de petróleo, elab. de comb. nucl. & 0,0 & 0,0 & 0,0 & 0,0 & 0,0 & 0,1 & 1,4 & 1,5 \\
\hline Fabricação de produtos químicos & 0,8 & 0,7 & 1,2 & 1,3 & 0,6 & 0,9 & 5,4 & 4,8 \\
\hline Fabricaçáo de produtos de minerais não metálicos & 1,6 & 1,7 & 4,1 & 2,7 & 3,5 & 3,5 & 5,4 & 4,8 \\
\hline Metalurgia básica & 2,3 & 2,6 & 4,0 & 7,7 & 2,8 & 1,2 & 4,5 & 3,5 \\
\hline Reciclagem & 0,0 & 0,2 & 0,0 & 0,2 & 0,1 & 0,4 & 0,1 & 0,3 \\
\hline Subtotal Commodities & 7,0 & 7,6 & 12,4 & 14,9 & 10,1 & 9,2 & 22,0 & 20,0 \\
\hline Fabricação de máquinas e equipamentos & 7,6 & 7,1 & 14,3 & 14,0 & 4,1 & 5,2 & 5,2 & 6,2 \\
\hline Fab. de máquinas para escritório e equip. de informática & 0,0 & 0,0 & 0,0 & 0,0 & 0,0 & 0,1 & 0,3 & 0,6 \\
\hline Fabricação de máquinas, aparelhos e materiais elétricos & 4,2 & 3,1 & 6,6 & 7,0 & 2,0 & 2,3 & 2,5 & 2,6 \\
\hline Fab. de material eletrônico, de aparelhos e equip. de com. & 0,3 & 0,4 & 0,1 & 0,4 & 0,3 & 0,3 & 1,4 & 1,2 \\
\hline Fabricação de equipamentos de instrumentação & 0,1 & 1,0 & 1,0 & 1,5 & 0,3 & 0,2 & 0,8 & 0,8 \\
\hline Fabricação de outros equipamentos de transporte & 0,1 & 0,1 & 0,0 & 0,0 & 0,6 & 1,2 & 0,6 & 1,2 \\
\hline Fab. e montagem de veículos auto., reboques e carrocerias & 13,1 & 17,3 & 3,9 & 3,5 & 1,7 & 2,1 & 5,9 & 5,7 \\
\hline Subtotal Difusora/Durável & 25,4 & 29,0 & 26,0 & 26,3 & 9,0 & 11,3 & 16,8 & 18,4 \\
\hline Fabricaçáo de produtos alimentícios e bebidas & 11,9 & 13,2 & 5,9 & 5,4 & 8,9 & 9,5 & 18,8 & 20,4 \\
\hline Fabricação de produtos têxteis & 3,8 & 2,8 & 9,9 & 8,2 & 29,5 & 26,4 & 5,8 & 4,7 \\
\hline Confecção de artigos do vestuário e acessórios & 2,6 & 3,0 & 10,2 & 11,5 & 23,9 & 26,0 & 7,2 & 8,3 \\
\hline Prep. de couros e fab. de artefatos de couro e calçados & 7,9 & 4,0 & 0,2 & 0,2 & 0,2 & 0,2 & 5,0 & 5,6 \\
\hline Fabricação de produtos de madeira & 4,6 & 3,0 & 8,5 & 6,5 & 6,8 & 5,0 & 4,1 & 3,2 \\
\hline Edição, impressão e reproduçáo de gravações & 1,9 & 1,8 & 1,5 & 1,2 & 1,8 & 1,4 & 4,1 & 3,1 \\
\hline Fabricação de artigos de borracha e plástico & 5,6 & 9,2 & 7,8 & 9,7 & 3,3 & 3,4 & 5,2 & 5,7 \\
\hline Fab. de produtos de metal - excl. máquinas e equip. & 12,2 & 12,1 & 4,9 & 6,4 & 3,3 & 4,8 & 6,0 & 6,4 \\
\hline Fabricação de móveis e indústrias diversas & 17,1 & 14,3 & 12,6 & 9,6 & 3,3 & 2,9 & 5,1 & 4,2 \\
\hline Subtotal Tradicional & 67,6 & 63,4 & 61,6 & 58,8 & 80,9 & 79,5 & 61,2 & 61,6 \\
\hline Total . . . . . . & 100,0 & $\ldots 0,0$ & $\ldots 100,0$ & $\ldots 100,0$ & 100,0 & 100,0 & $\ldots 100,0$ & $\ldots 100,0$ \\
\hline Total Absoluto . & 94.894 & 148.876 & 94.000 & 154.862 & 95.806 & 176.264 & 4.769 .855 & 7.093 .368 \\
\hline
\end{tabular}

Fonte: RAIS 
A importância da fabricação e da montagem de veículos automotores mesorregião Nordeste Rio-Grandense é confirmada mais uma vez apresentando participação de 25,9\% na massa de salários paga na mesorregiáo em 2007. Por outro lado, quase $20 \%$ do total de salários na mesorregião Norte Catarinense concentra-se na fabricação de máquinas e equipamentos. $\mathrm{O}$ peso da indústria têxtil e do vestuário na mesorregiāo do Vale do Itajaí permanece bastante elevado quando considerados os salários, embora um pouco menor do que quando utilizado o nível de emprego. Em outras palavras, os dados salariais confirmam a importância de alguns setores da indústria de transformação já destacados com a utilização da variável emprego.

Verifica-se, portanto, que as três mesorregióes de relativo sucesso na região Sul se desenvolveram a partir de indústrias distintas com especialização em divisóes diferenciadas da indústria de transformação. Enquanto o Norte Catarinense e o Nordeste Rio-Grandense se destacam em algumas divisóes da indústria difusora/durável, no Vale do Itajaí o destaque são duas divisóes da indústria tradicional. Nos três casos, entretanto, a maior parte do emprego e dos salários está concentrada na indústria tradicional, como, por sinal, é o caso da indústria brasileira como um todo.

\section{2_Cinco mesorregióes com forte crescimento do emprego}

Foram selecionadas para análise nesta seção cinco mesorregióes que passaram por grandes transformaçóes no período com elevado crescimento do emprego e forte aumento do índice de densidade na década. Nos cinco casos, tal índice superava o valor unitário em 2007, acima, portanto, a média nacional. Tais regióes representavam pouco menos de 3\% do emprego industrial do país em 2007. Cada uma possui características específicas servindo para ilustrar o complexo processo de desconcentração regional da indústria no país. Da mesma forma que nas três mesorregióes da região Sul analisadas acima, serão utilizadas as informaçóes relativas ao nível de emprego e à massa de salários pagos.

O primeiro caso é a mesorregiáo Norte Fluminense localizada no Estado do Rio de Janeiro. Ao longo da década, seu nível de emprego quase triplicou, passando de pouco mais de 13 mil empregos para quase 39 mil empregos. Seu índice de densidade passou de 0,65 para 1,31. A mesorregiáo Norte Fluminense é composta de duas microrregióes (Macaé e Campos dos Goytacazes) e de nove municípios, sendo o principal Macaé. Ela foi beneficiada no passado recente pelas atividades relacionadas à exploração de petróleo, lideradas pela Petrobras. 
Tabela 14_Distribuição dos salários por divisão e tipo de indústria - mesorregióes selecionadas da região sul - 1997/2007

\section{Divisão da Indústria Segundo o Tipo de Indústria}

\begin{tabular}{|c|c|c|c|c|c|c|c|}
\hline \multicolumn{2}{|c|}{ Nordeste Rio-Grandense } & \multicolumn{2}{|c|}{ Norte Catarinense } & \multicolumn{2}{|c|}{ Vale do Itajaí } & \multicolumn{2}{|l|}{ Brasil } \\
\hline 1997 & 2007 & 1997 & 2007 & 1997 & 2007 & 1997 & 2007 \\
\hline 0,0 & 0,0 & 0,0 & 0,0 & 0,0 & 0,0 & 0,1 & 0,1 \\
\hline 0,0 & 0,0 & 0,0 & 0,5 & 0,9 & 0,9 & 0,5 & 4,5 \\
\hline 0,0 & 0,0 & 0,0 & 0,0 & 0,0 & 0,0 & 0,9 & 1,2 \\
\hline 0,3 & 0,4 & 0,3 & 0,4 & 0,5 & 0,4 & 0,9 & 0,8 \\
\hline 0,0 & 0,0 & 0,0 & 0,2 & 0,8 & 0,5 & 0,6 & 0,4 \\
\hline 1,2 & 1,5 & 2,7 & 2,4 & 2,1 & 2,6 & 2,9 & 2,8 \\
\hline 0,0 & 0,0 & 0,0 & 0,0 & 0,0 & 0,1 & 1,5 & 2,2 \\
\hline 0,8 & 0,7 & 1,5 & 1,6 & 0,8 & 1,1 & 9,7 & 9,1 \\
\hline 0,8 & 1,2 & 2,4 & 2,0 & 2,5 & 3,3 & 3,8 & 3,4 \\
\hline 4,0 & 2,9 & 5,0 & 11,0 & 3,3 & 1,9 & 6,8 & 5,2 \\
\hline 0,0 & 0,2 & 0,0 & 0,1 & 0,1 & 0,3 & 0,1 & 0,2 \\
\hline 7,2 & 6,8 & 11,8 & 18,2 & 10,9 & 11,1 & 27,7 & 29,8 \\
\hline 8,4 & 8,7 & 18,7 & 19,5 & 5,8 & 7,5 & 7,2 & 8,2 \\
\hline 0,0 & 0,0 & 0,0 & 0,0 & 0,1 & 0,1 & 0,6 & 0,7 \\
\hline 11,2 & 3,5 & 9,5 & 7,3 & 2,4 & 2,6 & 3,2 & 2,9 \\
\hline 0,2 & 0,3 & 0,0 & 0,5 & 0,3 & 0,4 & 2,1 & 1,5 \\
\hline 0,1 & 0,9 & 1,9 & 1,5 & 0,2 & 0,1 & 0,9 & 0,9 \\
\hline 0,0 & 0,1 & 0,0 & 0,0 & 0,8 & 1,8 & 1,0 & 2,3 \\
\hline 18,7 & 25,9 & 5,1 & 4,2 & 2,2 & 2,7 & 12,7 & 10,0 \\
\hline 38,5 & 39,5 & 35,3 & 32,9 & 11,8 & 15,1 & 27,7 & 26,6 \\
\hline 8,8 & 9,5 & 5,5 & 4,3 & 7,9 & 11,0 & 13,8 & 14,6 \\
\hline 2,5 & 2,1 & 8,6 & 7,3 & 35,4 & 28,0 & 4,3 & 3,4 \\
\hline 1,4 & 1,8 & 11,1 & 9,0 & 19,6 & 19,4 & 3,4 & 3,9 \\
\hline 5,1 & 2,9 & 0,1 & 0,1 & 0,1 & 0,1 & 2,5 & 2,8 \\
\hline 2,4 & 1,8 & 3,8 & 3,6 & 3,4 & 3,6 & 1,8 & 1,8 \\
\hline 1,5 & 1,5 & 1,3 & 1,0 & 2,1 & 1,4 & 5,2 & 3,5 \\
\hline 4,6 & 8,3 & 9,1 & 10,4 & 3,4 & 2,9 & 4,9 & 5,2 \\
\hline 16,1 & 13,9 & 4,3 & 6,6 & 3,2 & 5,2 & 5,6 & 5,8 \\
\hline 12,0 & 11,9 & 9,0 & 6,7 & 2,3 & 2,3 & 3,1 & 2,6 \\
\hline 54,3 & 53,7 & 52,8 & 48,9 & 77,4 & 73,8 & 44,6 & 43,6 \\
\hline$\ldots 100,0$ & $\ldots 100,0$ & $\ldots 100,0$ & $\ldots 100,0$ & $\ldots 100,0$ & $\ldots 100,0$ & $\ldots 100,0$ & 100,0 \\
\hline 7.225 .326 & 6.514 .850 & 7.282 .620 & 6.853 .830 & 5.845 .978 & 6.320 .309 & 381.783 .799 & 334.592 .588 \\
\hline
\end{tabular}

Extraçáo carvão mineral

Extração de petroleo e serviços relacionados

Extração de minerais metálicos

Extração minerais não metálicos

Fabricação de produtos do fumo

Fab. de celulose, papel e produtos de papel

Fabricação de coque, refino de petróleo,

elaboração de combustível nuclear

Fabricação de produtos químicos

Fabricação de produtos de

minerais não metálicos

Metalurgia básica

\section{Reciclagem}

Subtotal Commodities

Fabricação de máquinas e equipamentos

Fabricação de máquinas para escritório e equipamento de informática

Fabricação de máquinas, aparelhos e

materiais elétricos

Fabricação de material eletrônico,

de aparelhos e equipamentos de computador

Fab. de equipamentos de instrumentação

Fab. de outros equipamentos de transporte

Fabricação e montagem de veículos

automotores, reboques e carrocerias

Subtotal Difusores/Duráveis

Fab. de produtos alimentícios e bebidas

Fabricação de produtos têxteis

Conf. de artigos do vestuário e acessórios

Prep. de couros e fabricaçấo de artefatos

de couro e calçados

Fabricação de produtos de madeira

Edição, impressão e reprodução de gravações

Fabricação de artigos de borracha e plástico

Fabricaçáo de produtos de metal -

exclusive máquinas e equipamentos

Fabricação de móveis e indústrias diversas

Subtotal Tradicional

Total

Total Absoluto

$\ldots \ldots \ldots \ldots r \mid \begin{array}{r}100,0 \\ 7.225 .326\end{array}$

\begin{tabular}{l|l|l|l|l}
6.514 .850 & 7.282 .620 & 6.853 .830
\end{tabular}

Fonte: RAIS

* Massa salarial em salários mínimos do ano 
A estrutura setorial do emprego e dos salários modificou-se radicalmente no período. Suas atividades estão basicamente concentradas na indústria de commodities, mais especificamente na extração de petróleo e serviços relacionados, que representava cerca de metade do emprego e $85 \%$ dos salários em 2007 (Tabelas 15 e 16). A mesorregião, que possuía no passado era tipicamente voltada para a indústria tradicional, com forte participação da indústria de produtos alimentícios e bebidas, passou por mudanças radicais no período por conta das atividades da indústria do petróleo, inclusive com a instalação da indústria de fabricação de máquinas e equipamentos na mesorregiẫo. Em um curto período de uma década, o Norte Fluminense transformou-se completamente em termos industriais.

A segunda mesorregiấo destacada é o Sul Goiano. Ela é composta de seis microrregiōes (Sudoeste de Goiás, Vale do Rio dos Bois, Meia Ponte, Pires do Rio, Catalão e Quirinópolis) e 82 municípios. Suas atividades estáo concentradas na indústria tradicional, principalmente em produtos alimentícios e bebidas. $\mathrm{O}$ volume de emprego passou de pouco menos de $15 \mathrm{mil} \mathrm{pa-}$ ra quase $53 \mathrm{mil}$ em apenas dez anos. $\mathrm{O}$ índice de densidade subiu de 0,47 para 1,15.

Além do forte crescimento no nível de emprego, a principal mudança ob- servada no período foi o aumento da importância da indústria difusora/durável, praticamente inexistente em 1997, porém representando dez anos depois 6,3\% dos empregos e 9,3\% da massa de salários, por conta do aumento da participação da fabricação e da montagem de veículos automotores. A montadora Mitsubishi se instalou no município de Catalão, no final dos anos noventas. Possui atualmente cerca de três mil empregados e anunciou a realização de novos investimentos nos próximos anos. Portanto, a importância da indústria difusora/durável deve aumentar na mesorregiáo do Sul Goiano nos próximos anos.

A mesorregião Oeste de Minas quase dobrou o número de empregos no período, totalizando pouco menos de $70 \mathrm{mil}$ em 2007. Ela possui cinco microrregióes (Piumhi, Divinópolis, Formiga, Campo Belo e Oliveira) e 44 municípios. Seu índice de densidade passou de 1,45 para 1,90 entre 1997 e 2007, representando o valor mais elevado entre as cinco mesorregióes selecionadas nesta seção. Em 2007, era a mesorregião com o maior índice de densidade entre as pertencentes ao Grupo Médio Superior.

A estrutura industrial do Oeste de Minas passou por pequenas transformaçóes na década, destacando-se principalmente pela forte elevação do nível 
de emprego. Sua atividade industrial está concentrada no segmento de commodities (metalurgia básica) e na indústria tradicional (artigos do vestuário e, principalmente, calçados).

O município de Nova Serrana, localizado na microrregião de Divinópolis, é um importante produtor de calçados, com a presença de um grande número de pequenas e microempresas. Provavelmente, import ante parcela dos empregos do segmento produtor de calçados em Nova Serrana é informal, não sendo contabilizada nas estatísticas da RAIS.

A quarta mesorregiáo selecionada é o Noroeste Espírito-Santense, que praticamente dobrou o número de empregos, chegando a quase $20 \mathrm{mil} \mathrm{em} \mathrm{2007.} \mathrm{Em}$ termos de índice de densidade, passou de 0,88 a 1,28 . A mesorregiáo inclui três microrregióes (Barra de São Francisco, Nova Venécia e Colatina) e 17 municípios.

Sua indústria está dividida em segmentos da indústria tradicional e de commodities, com tendência de crescimento da importância dos últimos. No período, a indústria de commodities aumentou em 14 pontos percentuais (pp) sua participação no emprego e 20 pp nos salários. Apesar da queda relativa, a indústria tradicional ainda representava 53\% do emprego e $64 \%$ dos salários em 2007, fortemente concentrada na produção de artigos pa- ra o vestuário e, em segundo lugar, em alimentos e bebidas. A indústria de commodities está voltada para a extração e a fabricação de produtos de minerais não metálicos, mas especificamente, granitos.

Encontram-se em Barra de Sáo Francisco grandes jazidas de granito. Sua exploração teve início nos anos oitentas, voltada para o mercado externo, sendo incrementada nas décadas seguintes. Além das jazidas em regime de extração, há inúmeras outras aguardando liberação da licença pelo Ministério de Minas e Energia, podendo-se prever aumento da atividade extrativa de granito nos próximos anos.

A última mesorregião escolhida é o Leste do Mato Grosso do Sul. Ela possui quatro microrregiōes (Cassilândia, Parnaíba, Três Lagoas e Nova Andradina) e 17 municípios. $O$ crescimento do emprego no período foi excepcional, passando de pouco mais de 5 mil para quase $18 \mathrm{mil} \mathrm{em}$ apenas dez anos. Consequentemente, houve forte elevação do índice de densidade, subindo de 0,59 para 1,30.

A principal mudança observada no período foi a diversificação de sua indústria tradicional, que em 2007 representava cerca de $80 \%$ dos empregos e salários industriais na região. Se em 1997 ela estava concentrada em alimentos, bebidas e produtos de madeira, em 2007 incluía também a indústria têxtil, do vestuário, 
produtos de couro, plásticos, etc. A contrapartida do aumento da participação da indústria tradicional foi a forte queda da importância da indústria de commodities. Cabe ainda acrescentar o aumento do papel da indústria difusora/durável. Praticamente inexistente em 1997, representava $5 \%$ do emprego e $7 \%$ dos salários em 2007, por conta da instalação na região do setor de máquinas e equipamentos.

Políticas ativas de atração de investimentos têm sido utilizadas na mesorregião Leste do Mato Grosso do Sul, como no caso do município de Três Lagoas, onde se instalou o conglomerado têxtil Avanti, Corttex, Addar e Fatex. Com isso, o município transformou-se no maior polo de tecelagem do estado.

Conforme verificado nesta seção, a dinâmica do comportamento da indústria nas cinco mesorregióes selecionadas para ilustrar o processo de desconcentração regional é bastante diferenciada, mostrando a complexidade e a riqueza do fenômeno que está ocorrendo no país.

\section{6_Conclusões}

O principal resultado deste trabalho é a confirmação de que o processo de desconcentração espacial da indústria brasileira continuou de forma bastante intensa nos anos 2000, beneficiando principalmen- te a região Sul do país. Por outro lado, foi identificado certo "esvaziamento" enfrentado pela indústria na Regiāo Metropolitana de São Paulo e em outras Regióes Metropolitanas do Sul/Sudeste.

A redução relativa da massa de salários e dos empregos industriais (e mesmo do VTI) nas regióes metropolitanas não representa obrigatoriamente perda de centralidade de tais regióes na atividade econômica. Muitas vezes o que está ocorrendo é a substituição da atividade industrial por atividades terciárias voltadas para a indústria. Segundo Diniz e Campolina (2007), no caso da Região Metropolitana de São Paulo, a queda da participação na produção industrial é compensada pela ampliaçáo de seu papel como centro financeiro e de serviços modernos de apoio à indústria.

$\mathrm{O}$ artigo mostra um movimento geral de deslocamento das atividades industriais em direção ao interior. Em geral, tal deslocamento se dirige para o interior da regiāo Sul/Sudeste. Mas também é observada uma migraçấo para o interior de regióes menos desenvolvidas do país, especialmente no Centro-Oeste.

A queda dos índices de concentração regional é generalizada, atingindo a indústria difusora, de commodities, de bens duráveis e a tradicional. Em pouquíssimos casos, em geral na indústria 
extrativa mineral, dependente da localização das jazidas minerais, não ficou caracterizada clara redução do nível de concentração regional do emprego e dos salários.

Apesar da redução dos desníveis regionais, a indústria brasileira continua bastante concentrada em um número relativamente pequeno de mesorregióes, em geral localizadas nas regióes mais desenvolvidas do país. De forma estilizada, pode-se afirmar que a queda da importância relativa da atividade estritamente industrial no período ocorreu basicamente nas quatro maiores Regióes Metropolitanas (SP, RJ, BH e POA), beneficiando, especialmente, aquelas de porte médio e, em menos escala, as menores. Houve ganhos nas mais distintas mesorregióes das diferentes regióes.

Foi proposto um novo índice de densidade industrial, comparando-se seus resultados com aqueles obtidos com a utilização do tradicional quociente locacional. Os resultados encontrados mostram maior coerência para o primeiro quando aplicado aos dados mesorregionais da RAIS da indústria brasileira.

Utilizando-se o índice de densidade industrial proposto no artigo, foi confirmada a importância de algumas mesorregiôes do interior do país. Além daquelas localizadas no Estado de São Paulo, houve destaque na região Sul em geral e no Esta- do de Santa Catarina em particular. Analisando-se três "casos de sucesso" na região Sul, verificou-se que modelos distintos podem ser seguidos para o desenvolvimento e a especialização da indústria local. Outros cinco casos de mesorregióes menos industrializadas em cinco estados distintos serviram para completar a ilustração do complexo processo da desconcentração regional da indústria brasileira. Verifica-se, portanto, que é preciso aproveitar as vantagens locacionais, eventuais economias e deseconomias de aglomeração, malha de transporte existente, etc., para se decidir qual indústria tem melhores condições de desenvolvimento na região.

Não foram discutidas com profundidade no artigo as razóes que teriam levado ao aumento da desconcentração regional da indústria, mas algumas hipóteses podem ser levantadas a partir das mesorregióes examinadas com mais detalhe na seçáo 5. Certamente, o crescimento da economia em geral, e da indústria em particular, na segunda metade do período analisado, deve ter dado sua contribuição, elevando o nível de emprego e os salários, e abrindo novas oportunidades de investimentos industriais. Por outro lado, a existência de vantagens fiscais, creditícias, logísticas e de infraestrutura oferecida pelos governos municipais representa importante fator de atração em 
Tahela 15 _Distribuição do emprego por divisão e tipo de indústria - mesorregiões selecionadas do país - 1997/2007

\begin{tabular}{|c|c|c|c|c|c|c|}
\hline \multirow{2}{*}{ Divisão da Indústria Segundo o Tipo de Indústria } & \multicolumn{2}{|c|}{ Oeste de Minas } & \multicolumn{2}{|c|}{ Noroeste Espírito-Santense } & \multicolumn{2}{|c|}{ Norte Fluminense } \\
\hline & 1997 & 2007 & 1997 & 2007 & 1997 & 2007 \\
\hline Extraçáo carvão mineral & 0,0 & 0,0 & 0,0 & 0,0 & 0,0 & 0,0 \\
\hline Extração de petroleo e serviços relacionados & 0,3 & 0,0 & 0,0 & 0,0 & 14,2 & 49,5 \\
\hline Extração de minerais metálicos & 0,2 & 0,6 & 0,0 & 0,0 & 0,0 & 0,2 \\
\hline Extração minerais não metálicos & 4,8 & 2,9 & 9,7 & 19,1 & 1,8 & 0,8 \\
\hline Fabricação de produtos do fumo & 0,0 & 0,0 & 0,0 & 0,0 & 0,2 & 0,0 \\
\hline Fabricaçáo de celulose, papel e produtos de papel & 1,0 & 1,6 & 0,0 & 0,0 & 0,1 & 0,1 \\
\hline Fabricaçáo de coque, refino de petróleo, elab. de comb.nucl. & 0,0 & 0,1 & 0,6 & 0,1 & 0,5 & 0,1 \\
\hline Fabricaçáo de produtos químicos & 9,0 & 5,0 & 0,0 & 0,2 & 1,6 & 0,7 \\
\hline Fabricação de produtos de minerais náo metálicos & 6,1 & 5,4 & 10,0 & 14,9 & 14,4 & 7,4 \\
\hline Metalurgia básica & 15,4 & 15,0 & 0,0 & 0,0 & 0,8 & 0,4 \\
\hline Reciclagem & 0,1 & 0,4 & 0,0 & 0,4 & 0,0 & 0,5 \\
\hline Subtotal Commodities & 36,9 & 30,9 & 20,4 & 34,8 & 33,6 & 59,5 \\
\hline Fabricaçáo de máquinas e equipamentos & 1,1 & 1,2 & 0,8 & 0,3 & 1,6 & 11,9 \\
\hline Fabricação de máquinas para escritório e equip. de informática & 0,0 & 0,0 & 0,0 & 0,1 & 0,0 & 0,0 \\
\hline Fabricação de máquinas, aparelhos e materiais elétricos & 0,3 & 0,3 & 0,0 & 0,0 & 0,0 & 0,1 \\
\hline Fabricação de material eletrônico, de aparelhos e equip. de com. & 0,0 & 0,0 & 0,0 & 0,0 & 0,1 & 0,0 \\
\hline Fabricação de equipamentos de instrumentação & 0,1 & 0,1 & 0,0 & 0,0 & 0,1 & 0,4 \\
\hline Fabricação de outros equipamentos de transporte & 0,0 & 0,0 & 0,0 & 0,0 & 0,9 & 0,4 \\
\hline Fabricação e montagem de veículos auto., reboques e carrocerias & 1,1 & 1,0 & 0,5 & 0,5 & 0,3 & 0,4 \\
\hline Subtotal Difusora/Durável & 2,6 & 2,6 & 1,3 & 1,0 & 3,0 & 13,2 \\
\hline Fabricação de produtos alimentícios e bebidas & 10,4 & 8,8 & 15,6 & 11,5 & 42,7 & 15,9 \\
\hline Fabricação de produtos têxteis & 9,5 & 5,9 & 1,5 & 2,1 & 2,2 & 0,3 \\
\hline Confecção de artigos do vestuário e acessórios & 18,4 & 18,7 & 45,7 & 42,4 & 6,2 & 2,0 \\
\hline Prep. de couros e fabricação de artefatos de couro e calçados & 12,2 & 22,1 & 0,5 & 0,1 & 0,4 & 0,2 \\
\hline Fabricaçáo de produtos de madeira & 0,6 & 0,6 & 3,1 & 2,0 & 0,4 & 0,2 \\
\hline Edição, impressão e reprodução de gravaçôes & 1,3 & 0,9 & 1,3 & 1,0 & 1,9 & 1,2 \\
\hline Fabricação de artigos de borracha e plástico & 1,9 & 3,2 & 1,1 & 0,6 & 0,9 & 0,3 \\
\hline Fabricação de produtos de metal - excl. máquinas e equip. & 2,2 & 2,8 & 4,3 & 2,3 & 6,4 & 6,5 \\
\hline Fabricação de móveis e indústrias diversas & 4,1 & 3,6 & 5,2 & 2,1 & 2,3 & 0,8 \\
\hline Subtotal Tradicional & 60,5 & 66,5 & 78,3 & 64,3 & 63,4 & 27,3 \\
\hline Total . . . . . . . . & 100,0 & $.100,0$ & $.100,0$ & 100,0 & 100,0 & 100,0 \\
\hline Total Absoluto & 36.105 & 69.334 & 10.088 & 19.773 & 13.156 & 38.693 \\
\hline
\end{tabular}


Tabela 15 _Distribuição do emprego por divisão e tipo de indústria - mesorregiões selecionadas do país - 1997/2007

\begin{tabular}{|c|c|c|c|c|c|c|}
\hline \multirow{2}{*}{ Divisão da Indústria Segundo o Tipo de Indústria } & \multicolumn{2}{|c|}{ Leste de Mato Grosso do Sul } & \multicolumn{2}{|l|}{ Sul Goiano } & \multicolumn{2}{|l|}{ Brasil } \\
\hline & 1997 & 2007 & 1997 & 2007 & 1997 & 2007 \\
\hline Extração carvão mineral & 0,0 & 0,5 & 0,0 & 0,0 & 0,1 & 0,1 \\
\hline Extração de petroleo e serviços relacionados & 0,0 & 0,0 & 0,1 & 0,0 & 0,2 & 0,7 \\
\hline Extração de minerais metálicos & 0,0 & 0,0 & 0,0 & 0,0 & 0,6 & 0,7 \\
\hline Extração minerais não metálicos & 4,9 & 0,2 & 4,9 & 2,0 & 1,4 & 1,1 \\
\hline Fabricação de produtos do fumo & 0,0 & 0,0 & 0,0 & 0,0 & 0,4 & 0,2 \\
\hline Fabricaçáo de celulose, papel e produtos de papel & 1,3 & 1,2 & 0,1 & 0,7 & 2,5 & 2,2 \\
\hline Fabricação de coque, refino de petróleo, elab. de comb.nucl. & 17,3 & 2,2 & 5,5 & 13,9 & 1,4 & 1,5 \\
\hline Fabricação de produtos químicos & 0,0 & 0,6 & 3,9 & 3,1 & 5,4 & 4,8 \\
\hline Fabricação de produtos de minerais não metálicos & 7,0 & 3,5 & 9,3 & 4,4 & 5,4 & 4,8 \\
\hline Metalurgia básica & 2,3 & 2,4 & 2,3 & 0,6 & 4,5 & 3,5 \\
\hline Reciclagem & 0,0 & 0,2 & 0,1 & 0,0 & 0,1 & 0,3 \\
\hline Subtotal Commodities & 32,9 & 10,8 & 26,1 & 24,9 & 22,0 & 20,0 \\
\hline Fabricação de máquinas e equipamentos & 0,1 & 3,5 & 0,3 & 1,6 & 5,2 & 6,2 \\
\hline Fabricação de máquinas para escritório e equip. de informática & 0,0 & 0,0 & 0,0 & 0,0 & 0,3 & 0,6 \\
\hline Fabricação de máquinas, aparelhos e materiais elétricos & 0,0 & 1,0 & 0,0 & 0,1 & 2,5 & 2,6 \\
\hline Fabricaçáo de material eletrônico, de aparelhos e equip. de com. & 0,0 & 0,0 & 0,0 & 0,0 & 1,4 & 1,2 \\
\hline Fabricaçáo de equipamentos de instrumentação & 0,0 & 0,0 & 0,1 & 0,1 & 0,8 & 0,8 \\
\hline Fabricaçáo de outros equipamentos de transporte & 0,0 & 0,0 & 0,1 & 0,2 & 0,6 & 1,2 \\
\hline Fabricação e montagem de veículos auto., reboques e carrocerias & 0,1 & 0,6 & 0,5 & 4,4 & 5,9 & 5,7 \\
\hline Subtotal Difusora/Durável & 0,2 & 5,1 & 0,9 & 6,3 & 16,8 & 18,4 \\
\hline Fabricação de produtos alimentícios e bebidas & 46,6 & 43,5 & 54,7 & 56,9 & 18,8 & 20,4 \\
\hline Fabricação de produtos têxteis & 0,1 & 9,0 & 2,7 & 1,5 & 5,8 & 4,7 \\
\hline Confecção de artigos do vestuário e acessórios & 3,3 & 4,9 & 6,7 & 3,1 & 7,2 & 8,3 \\
\hline Prep. de couros e fabricação de artefatos de couro e calçados & 1,3 & 7,4 & 1,1 & 1,9 & 5,0 & 5,6 \\
\hline Fabricação de produtos de madeira & 9,8 & 6,9 & 0,8 & 0,3 & 4,1 & 3,2 \\
\hline Edição, impressão e reprodução de gravações & 1,6 & 1,4 & 1,9 & 0,7 & 4,1 & 3,1 \\
\hline Fabricação de artigos de borracha e plástico & 0,5 & 6,8 & 0,7 & 1,5 & 5,2 & 5,7 \\
\hline Fabricação de produtos de metal - excl. máquinas e equip. & 1,9 & 2,6 & 3,1 & 2,7 & 6,0 & 6,4 \\
\hline Fabricação de móveis e indústrias diversas & 1,8 & 1,6 & 1,3 & 0,4 & 5,1 & 4,2 \\
\hline Subtotal Tradicional & 66,9 & 84,0 & 72,9 & 68,8 & 61,2 & 61,6 \\
\hline $\begin{array}{l}\text { Total } \\
\text { Total Absoluto }\end{array}$ & $\begin{array}{l}100,0 \\
5.349\end{array}$ & $\begin{array}{l}100,0 \\
17.765\end{array}$ & $\begin{array}{r}100,0 \\
14.678\end{array}$ & $\begin{aligned} 100,0 \\
52.903\end{aligned}$ & $\begin{aligned} 100,0 \\
4.769 .855\end{aligned}$ & $\begin{array}{l}\ldots 100,0 \\
7.093 .368\end{array}$ \\
\hline
\end{tabular}


Tabela 16_Distribuição dos salários por divisão e tipo de Indústria - mesorregiões selecionadas do país - 1997/2007

\begin{tabular}{|c|c|c|c|c|c|c|}
\hline \multirow{2}{*}{ Divisão da Indústria Segundo o Tipo de Indústria } & \multicolumn{2}{|c|}{ Deste de Minas } & \multicolumn{2}{|c|}{ Noroeste Espíritosantense } & \multicolumn{2}{|c|}{ Norte Fluminense } \\
\hline & 1997 & 2007 & 1997 & 2007 & 1997 & 2007 \\
\hline Extração carvão mineral & 0,0 & 0,0 & 0,0 & 0,0 & 0,0 & 0,0 \\
\hline Extração de petroleo e serviços relacionados & 0,1 & 0,0 & 0,0 & 0,0 & 41,4 & 85,2 \\
\hline Extração de minerais metálicos & 0,4 & 1,5 & 0,0 & 0,0 & 0,0 & 0,1 \\
\hline Extração minerais não-metálicos & 6,3 & 4,4 & 16,5 & 30,3 & 1,0 & 0,1 \\
\hline Fabricação de produtos do fumo & 0,0 & 0,0 & 0,0 & 0,0 & 0,5 & 0,0 \\
\hline Fabricação de celulose, papel e produtos de papel & 0,9 & 1,4 & 0,0 & 0,0 & 0,0 & 0,0 \\
\hline Fab. de coque, refino de petróleo, elab. de comb.nucl. & 0,0 & 0,0 & 1,0 & 0,2 & 1,5 & 0,0 \\
\hline Fabricação de produtos químicos & 7,6 & 5,3 & 0,0 & 0,2 & 2,1 & 0,4 \\
\hline Fabricação de produtos de minerais não-metálicos & 7,0 & 5,7 & 8,8 & 15,5 & 5,0 & 0,7 \\
\hline Metalurgia básica & 22,7 & 23,0 & 0,0 & 0,0 & 0,8 & 0,1 \\
\hline Reciclagem & 0,1 & 0,3 & 0,0 & 0,3 & 0,0 & 0,1 \\
\hline Subtotal Commodities & 45,2 & 41,8 & 26,4 & 46,5 & 52,3 & 86,6 \\
\hline Fabricação de máquinas e equipamentos & 1,4 & 1,5 & 0,6 & 0,3 & 1,8 & 7,5 \\
\hline Fab. de máquinas para escritório e equip. de informática & 0,0 & 0,0 & 0,0 & 0,1 & 0,0 & 0,0 \\
\hline Fabricação de máquinas, aparelhos e materiais elétricos & 0,4 & 0,4 & 0,0 & 0,0 & 0,0 & 0,2 \\
\hline Fab. de material eletrônico, de aparelhos e equip. de com. & 0,0 & 0,0 & 0,0 & 0,0 & 0,1 & 0,0 \\
\hline Fabricação de equipamentos de instrumentação & 0,0 & 0,1 & 0,0 & 0,0 & 0,0 & 0,3 \\
\hline Fabricação de outros equipamentos de transporte & 0,0 & 0,0 & 0,1 & 0,0 & 0,7 & 0,1 \\
\hline Fab. e montagem de veículos auto., reboques e carrocerias & 2,2 & 1,2 & 0,4 & 0,5 & 0,1 & 0,0 \\
\hline Subtotal Difusora/Durável & 4,0 & 3,2 & 1,0 & 0,8 & 2,7 & 8,1 \\
\hline Fabricação de produtos alimentícios e bebidas & 12,0 & 7,9 & 19,6 & 11,6 & 34,5 & 2,3 \\
\hline Fabricação de produtos têxteis & 11,4 & 5,9 & 1,4 & 1,7 & 0,8 & 0,0 \\
\hline Confecção de artigos do vestuário e acessórios & 11,8 & 13,4 & 36,0 & 32,1 & 1,8 & 0,2 \\
\hline Prep. de couros e fabrç. de artefatos de couro e calçados & 7,8 & 16,7 & 0,3 & 0,1 & 0,1 & 0,0 \\
\hline Fabricação de produtos de madeira & 0,4 & 0,6 & 2,5 & 1,4 & 0,1 & 0,0 \\
\hline Edição, impressão e reprodução de gravações & 0,9 & 0,8 & 1,7 & 0,9 & 0,9 & 0,2 \\
\hline Fabricação de artigos de borracha e plástico & 1,8 & 3,1 & 1,1 & 0,6 & 0,4 & 0,1 \\
\hline Fab. de produtos de metal - excl. máquinas e equip. & 2,1 & 3,1 & 6,0 & 2,4 & 5,7 & 2,4 \\
\hline Fabricação de móveis e indústrias diversas & 2,5 & 3,5 & 4,1 & 1,8 & 0,8 & 0,1 \\
\hline Subtotal Tradicional & 50,8 & 55,0 & 72,6 & 52,7 & 45,0 & 5,2 \\
\hline Total . . . . . . . & $\ldots 100,0$ & $\ldots 100,0$ & 100,0 & 100,0 & $\ldots 100,0$ & $\ldots 100,0$ \\
\hline Total Absoluto . & 1.214 .326 & 1.645 .302 & 275.254 & 479.526 & 816.334 & 6.593 .245 \\
\hline
\end{tabular}


Tabela 16_Distribuição dos salários por divisão e tipo de Indústria - mesorregióes selecionadas do país - 1997/2007

\begin{tabular}{|c|c|c|c|c|c|c|}
\hline \multirow{2}{*}{ Divisão da Indústria Segundo o Tipo de Indústria } & \multicolumn{2}{|c|}{ Leste de Mato Grosso do Sul } & \multicolumn{2}{|c|}{ Sul Goiano } & \multicolumn{2}{|l|}{ Brasil } \\
\hline & 1997 & 2007 & 1997 & 2007 & 1997 & 2007 \\
\hline Extração carvão mineral & 0,0 & 0,3 & 0,0 & 0,0 & 0,1 & 0,1 \\
\hline Extração de petroleo e serviços relacionados & 0,0 & 0,0 & 0,1 & 0,0 & 0,5 & 4,5 \\
\hline Extração de minerais metálicos & 0,0 & 0,0 & 0,0 & 0,0 & 0,9 & 1,2 \\
\hline Extração minerais não-metálicos & 8,3 & 0,3 & 9,3 & 2,9 & 0,9 & 0,8 \\
\hline Fabricação de produtos do fumo & 0,0 & 0,0 & 0,0 & 0,0 & 0,6 & 0,4 \\
\hline Fabricação de celulose, papel e produtos de papel & 3,5 & 2,0 & 0,0 & 0,9 & 2,9 & 2,8 \\
\hline Fab. de coque, refino de petróleo, elab. de comb.nucl. & 33,4 & 4,6 & 7,2 & 17,6 & 1,5 & 2,2 \\
\hline Fabricação de produtos químicos & 0,0 & 0,7 & 6,2 & 6,1 & 9,7 & 9,1 \\
\hline Fabricação de produtos de minerais não-metálicos & 3,1 & 2,8 & 7,3 & 3,1 & 3,8 & 3,4 \\
\hline Metalurgia básica & 2,8 & 3,0 & 4,3 & 1,5 & 6,8 & 5,2 \\
\hline Reciclagem & 0,0 & 0,1 & 0,0 & 0,0 & 0,1 & 0,2 \\
\hline Subtotal Commodities & 51,2 & 13,9 & 34,5 & 32,2 & 27,7 & 29,8 \\
\hline Fabricação de máquinas e equipamentos & 0,1 & 5,2 & 0,2 & 2,1 & 7,2 & 8,2 \\
\hline Fab. de máquinas para escritório e equip. de informática & 0,0 & 0,0 & 0,0 & 0,0 & 0,6 & 0,7 \\
\hline Fabricação de máquinas, aparelhos e materiais elétricos & 0,0 & 1,0 & 0,0 & 0,1 & 3,2 & 2,9 \\
\hline Fab. de material eletrônico, de aparelhos e equip. de com. & 0,0 & 0,0 & 0,0 & 0,0 & 2,1 & 1,5 \\
\hline Fabricação de equipamentos de instrumentaçáo & 0,0 & 0,0 & 0,0 & 0,0 & 0,9 & 0,9 \\
\hline Fabricação de outros equipamentos de transporte & 0,0 & 0,0 & 0,0 & 0,1 & 1,0 & 2,3 \\
\hline Fab. e montagem de veículos auto., reboques e carrocerias & 0,0 & 0,6 & 0,3 & 7,0 & 12,7 & 10,0 \\
\hline Subtotal Difusora/Durável & 0,1 & 6,9 & 0,6 & 9,3 & 27,7 & 26,6 \\
\hline Fabricação de produtos alimentícios e bebidas & 38,9 & 46,4 & 54,6 & 49,5 & 13,8 & 14,6 \\
\hline Fabricação de produtos têxteis & 0,1 & 9,1 & 2,0 & 1,2 & 4,3 & 3,4 \\
\hline Confecção de artigos do vestuário e acessórios & 1,6 & 3,0 & 2,6 & 1,9 & 3,4 & 3,9 \\
\hline Prep. de couros e fabrç. de artefatos de couro e calçados & 0,7 & 5,1 & 0,6 & 1,3 & 2,5 & 2,8 \\
\hline Fabricação de produtos de madeira & 4,6 & 5,5 & 0,3 & 0,1 & 1,8 & 1,8 \\
\hline Edição, impressão e reprodução de gravaçóes & 0,9 & 1,1 & 1,1 & 0,4 & 5,2 & 3,5 \\
\hline Fabricação de artigos de borracha e plástico & 0,3 & 4,9 & 0,4 & 1,2 & 4,9 & 5,2 \\
\hline Fab. de produtos de metal - excl. máquinas e equip. & 1,0 & 2,9 & 2,7 & 2,6 & 5,6 & 5,8 \\
\hline Fabricação de móveis e indústrias diversas & 0,7 & 1,1 & 0,5 & 0,2 & 3,1 & 2,6 \\
\hline Subtotal Tradicional & 48,7 & 79,2 & 65,0 & 58,5 & 44,6 & 43,6 \\
\hline Total . . . . . . . & 100,0 & 100,0 & 100,0 & $\ldots 100,0$ & 100,0 & 100,0 \\
\hline Total Absoluto & 241.656 & 460.881 & 660.007 & 1.789 .823 & 381.783.799| & 334.592 .588 \\
\hline
\end{tabular}

Fonte: RAIS

* massa salarial em salários mínimos do ano 
diversas regiōes com distintos níveis de desenvolvimento no interior do país. A maior ou menor oferta de mão de obra e os menores níveis salariais existentes fora dos grandes centros também são um elemento que não pode ser negligenciado. Ao mesmo tempo, aglomeraçóes já excessivamente grandes com problemas ambientais, maior organização dos trabalhadores e salários mais elevados podem influenciar negativamente na realização de novos investimentos industriais nas grandes metrópoles.

No Norte Fluminense, a chegada da Petrobras foi fundamental para o desenvolvimento da indústria local, inclusive com a instalação de alguns fornecedores na regiāo. No Noroeste Espírito-Santense, a exploração de novas jazidas minerais existentes, mas anteriormente não exploradas, parece ter dado um impulso importante na região. No Sul Goiano, a instalação de uma montadora de veículos parece ter sido fundamental para seu desenvolvimento. A marca registrada do Oeste de Minas é a existência de um importante polo calçadista com grande número de pequenas empresas puxando a indústria local. No Leste do Mato Grosso do Sul, a instalação da indústria têxtil marcou o salto recente da regiáo. Enfim, os exemplos são os mais variados, e não há uma única causa ou modelo para ex- plicar o processo de desconcentração regional da indústria no país.

$\mathrm{O}$ artigo sugere direções possíveis de pesquisa para melhor entendimento do processo de desconcentração espacial da indústria no Brasil. A principal sugestão seria a realização de estudos nas mesorregióes (microrregióes e municípios) que têm se destacado no crescimento da atividade industrial, especialmente naquelas onde foram encontrados os maiores níveis e/ ou maior crescimento dos índices de densidade. A melhor compreensão do processo certamente exigirá a utilização de maior desagregação tanto regional quanto setorial. Em outras palavras, seria desejável a passagem do nível mais macro, desenvolvido neste trabalho, para um nível mais micro mediante estudos locais.

Finalizando, o quadro traçado no artigo em termos das tendências observadas é sem dúvida positivo. Ele aponta para uma nítida reduçâo dos desníveis regionais na indústria, embora permaneçam ainda bastante elevados. De qualquer forma, a tendência encontrada indica que, mantido o crescimento econômico e incentivado por uma política de descentralização favorável ao desenvolvimento das regiôes mais atrasadas, o setor industrial deverá responder positivamente, podendo caminhar no futuro para uma redução ainda maior da concentração regional da indústria no país. 


\section{Referências bibliográficas}

ANDRADE, T. A., SERRA, R. V. Distribuição espacial da indústria: Possibilidades atuais para sua investigação. Estudos Econômicos, v. 30, n. 2, abr./jun. 2000.

ARDISSONE, M. S. Mudança na distribuição espacial das atividades industriais por microrregiäo no periodo 1996/2005. 2009. $410 \mathrm{f}$.

Tese (Doutorado em Ciências

Econômicas) - Instituto de Economia, Universidade Federal do Rio de Janeiro, Rio de Janeiro, 2009.

AZEVEDO, P. F., TONETO JÚNIOR, R. Relocalização do emprego industrial formal no Brasil na década de 90. Pesquisa e Planejamento Econômico, v. 31, n. 1, abr. 2001.

AZZONI, C. R. Sobre a necessidade da politica regional. In: KON, A. Unidade e fragmentação: A questáo regional no Brasil. São Paulo: Perspectiva, 2002.

CROCCO, M. A. et al.

Metodologia de identificação dos arranjos produtivos locais. Nova Economia, v. 16, n. 2, ago. 2006.

DINIZ, C. C. Desenvolvimento poligonal no Brasil: Nem desconcentração, nem contínua polarização. Nova Economia, v. 3, n. 1, set. 1993.
DINIZ, C. C.; CROCCO, M. A. Reestruturação econômica e impacto regional: O novo mapa da indústria brasileira. Nova Economia, v. 6, n. 1, jul. 1996.

\section{DINIZ, C. C.; CAMPOLINA,}

B. A Região Metropolitana de São Paulo: Reestruturação, reespacialização e novas funçôes. Revista Eure, v. 33, 2007.

FERRAZ, J. C.; KUPFER, D. E HAGUENAUER, L. Made in Brazil: Desafios competitivos para a indústria brasileira. Rio de Janeiro: Campus, 1996.

GARCIA, R. A.; LEMOS, M. B.; CARVALHO, J. A. M. A evolução das áreas de influência demográfica e econômico-demográfica dos pólos econômicos brasileiros entre 1980, 1991 e 2000. Texto para Discussão, n. 224, Cedeplar, Belo Horizonte, out. 2003.

LEMOS, M. B. et. al. A nova configuração regional brasileira e sua geografia econômica. Estudos Econômicos, v. 33, n. 4, out./dez. 2003.
LEMOS, M. B. et al. A organizaçáo territorial da indústria no Brasil. In: DE NEGRI, J. A.; SALERNO, M. S. Inovaçōes, padröes tecnológicose desempenho das firmas industriais brasileiras. IPEA. Rio de Janeiro: IPEA, 2005.

NEGRI, B. Concentração e desconcentração industrial em São Paulo (1880-1990). 1994. $280 \mathrm{f}$ Tese (Doutorado em Economia) - Universidade Estadual de Campinas, Campinas, 1994.

OLIVEIRA JÚNIOR, M.

Aglomeração espacial e eficiência industrial: Um estudo a partir da evoluçáo da produtividade nos municípios brasileiros de 1970 a 1996. 2006. Tese (Doutorado em Ciências Econômicas) - Instituto de Economia, Universidade Federal do Rio de Janeiro, Rio de Janeiro, 2006.

PACHECO, C. A. Novos padróes de localização industrial?

Tendências recentes dos indicadores da produção e do investimento industrial. Texto para Discussão, n. 633. IPEA, Brasília, mar. 1999.
PEREIRA, F. M.; LEMOS, M. B. Cidades médias brasileiras: Características e dinâmicas urbano-industriais. Pesquisa e Planejamento Econômico, v. 33, n. 1, abr. 2003.

RAMOS, L.; FERREIRA, V. Geração de empregos e realocação espacial do mercado de trabalho brasileiro - 1992-2002. Pesquisa e Planejamento Econômico, v. 35, n. 1 , abr. 2005

SABOIA, J. Descentralização industrial no Brasil nos anos 90: Um enfoque regional. Pesquisa e Planejamento Econômico, v. 30, n. 1 , abr. 2000.

SABOIA, J. Descentralização industrial no Brasil na década de noventa: Um processo dinâmico e diferenciado regionalmente. Nova Economia, v. 11, n. 2, dez. 2001.

SABOIA, J. A indústria brasileira no Nordeste e as desigualdades inter e intra-regionais. Econômica, v. 6 , n. 1 , jun. 2004

SABOIA, J.; KUBRUSLY, L. S.; BARROS, A. C. Diferenciação regional da indústria brasileira: Agrupamento e ordenação a partir de um novo índice. Nova Economia, v. 18, n. 3, dez. 2008. 
SENAI - Geração do Emprego Industrial nas Capitais e Interior do Brasil. Brasília, 2005.

SUZIGAN, W.; FURTADO, J.; GARCIA, R.; SAMPAIO, S. E.

K. Aglomerações industriais no

Estado de São Paulo. Economia

Aplicada, v. 5, n. 4, out./dez. 2001.

O autor agradece a Jéssica

Teles, Liana Duque, Marcio

Carvalhal, Marcos Lyra

e Yan Paiva pelo apoio no processamento dos dados utilizados neste artigo. $O$ autor agradece ainda às críticas e sugestöes feitas por dois pareceristas anônimos. $O$ trabalho contou também com o apoio do CNPq por meio de bolsas de produtividade ao autor e de iniciação cientifica aos cinco assistentes.

E-mail de contato dos autores: saboia@ie.ufrj.br

Artigo recebido em abril de 2010 e aprovado em agosto de 2010 
Tahela A1_Distribuição do emprego nas mesorregiões do primeiro grupo* - 1997/2007

\begin{tabular}{|c|c|c|c|c|c|c|c|}
\hline \multicolumn{2}{|r|}{ Mesorregiáo } & \multirow{2}{*}{$\frac{\text { Empregos }}{1.049 .531}$} & \multirow{2}{*}{$\%$} & \multicolumn{2}{|c|}{ Mesorregião } & \multirow{2}{*}{$\frac{\text { Empregos }}{1.121 .561}$} & \multirow{2}{*}{$\frac{\%}{15,8}$} \\
\hline SP & Metropolitana de Sáo Paulo & & & SP & Metropolitana de São Paulo & & \\
\hline RJ & Metropolitana do Rio de Janeiro & 260.772 & 5,5 & RS & Metropolitana de Porto Alegre & 315.653 & 4,4 \\
\hline RS & Metropolitana de Porto Alegre & 245.855 & 5,2 & SP & Campinas & 302.869 & 4,3 \\
\hline MG & Metropolitana de Belo Horizonte & 215.659 & 4,5 & MG & Metropolitana de Belo Horizonte & 283.458 & 4,0 \\
\hline SP & Campinas & 200.990 & 4,2 & RJ & Metropolitana do Rio de Janeiro & 266.051 & 3,8 \\
\hline \multicolumn{2}{|c|}{ Subtotal } & 1.972 .807 & 41,4 & \multicolumn{2}{|c|}{ Subtotal } & 2.289 .592 & 32,3 \\
\hline \multicolumn{2}{|c|}{ Total } & 4.769 .855 . & 100,0 . & \multicolumn{2}{|c|}{ Total } & 7.093.368. & 100,0 \\
\hline
\end{tabular}

Fonte: RAIS

(*) 5 mesorregiōes com maior número de empregos 
Tabela A2_Distribuição do emprego nas mesorregiões do segundo grupo* - 1997/2007

\begin{tabular}{|c|c|c|c|c|c|c|c|}
\hline \multicolumn{2}{|c|}{ Mesorregião } & \multirow{2}{*}{$\begin{array}{c}\text { Empregos } \\
139.994\end{array}$} & \multirow{2}{*}{$\frac{\%}{2,9}$} & \multicolumn{2}{|c|}{ Mesorregião } & \multirow{2}{*}{$\frac{\text { Empregos }}{217.949}$} & \multirow{2}{*}{$\begin{array}{l}\% \\
3,1\end{array}$} \\
\hline SP & $\begin{array}{r}\text { Macro Metropolitana } \\
\text { Paulista }\end{array}$ & & & SP & $\begin{array}{r}\text { Macro Metropolitana } \\
\text { Paulista }\end{array}$ & & \\
\hline $\mathrm{PR}$ & Metropolitana de Curitiba & 122.788 & 2,6 & $\mathrm{PR}$ & Metropolitana de Curitiba & 195.522 & 2,8 \\
\hline SC & Vale do Itajaí & 95.806 & 2,0 & SC & Vale do Itajaí & 176.264 & 2,5 \\
\hline RS & Nordeste Rio-Grandense & 94.894 & 2,0 & SP & Ribeirão Preto & 156.051 & 2,2 \\
\hline SC & Norte Catarinense & 94.000 & 2,0 & SC & Norte Catarinense & 154.862 & 2,2 \\
\hline $\mathrm{CE}$ & Metropolitana de Fortaleza & 89.156 & 1,9 & RS & Nordeste Rio-Grandense & 148.876 & 2,1 \\
\hline SP & Vale do Paraíba Paulista & 86.523 & 1,8 & SP & Piracicaba & 145.784 & 2,1 \\
\hline SP & Piracicaba & 86.184 & 1,8 & $\mathrm{CE}$ & Metropolitana de Fortaleza & 137.467 & 1,9 \\
\hline SP & Ribeirão Preto & 78.834 & 1,7 & PR & Norte Central Paranaense & 136.126 & 1,9 \\
\hline PE & Metropolitana de Recife & 76.888 & 1,6 & SP & Vale do Paraíba Paulista & 123.843 & 1,7 \\
\hline PR & Norte Central Paranaense & 74.440 & 1,6 & MG & Sul/Sudoeste de Minas & 123.702 & 1,7 \\
\hline MG & Sul/Sudoeste de Minas & 70.222 & 1,5 & $\mathrm{GO}$ & Centro Goiano & 109.666 & 1,5 \\
\hline $\mathrm{AL}$ & Leste Alagoano & 61.271 & 1,3 & SC & Oeste Catarinense & 108.813 & 1,5 \\
\hline $\mathrm{GO}$ & Centro Goiano & 59.229 & 1,2 & AM & Centro Amazonense & 107.766 & 1,5 \\
\hline SC & Oeste Catarinense & 59.209 & 1,2 & $\mathrm{AL}$ & Leste Alagoano & 98.137 & 1,4 \\
\hline SP & Bauru & 58.079 & 1,2 & BA & Metropolitana de Salvador & 94.442 & 1,3 \\
\hline MG & Zona da Mata & 54.556 & 1,1 & SP & Bauru & 93.985 & 1,3 \\
\hline BA & Metropolitana de Salvador & 54.212 & 1,1 & $\mathrm{PE}$ & Metropolitana de Recife & 89.264 & 1,3 \\
\hline AM & Centro Amazonense & 53.978 & 1,1 & MG & $\begin{array}{r}\text { Triângulo Mineiro/Alto } \\
\text { Paranaíba } \\
\end{array}$ & 84.994 & 1,2 \\
\hline RS & Noroeste Rio-Grandense & 47.736 & 1,0 & RS & Noroeste Rio-Grandense & 80.814 & 1,1 \\
\hline \multicolumn{2}{|c|}{ Subtotal } & 1.557 .999 & 32,7 & \multicolumn{2}{|c|}{ Subtotal } & 2.584 .327 & 36,4 \\
\hline \multicolumn{2}{|c|}{ Total } & 4.769 .855 & 100,0 & \multicolumn{2}{|c|}{ Total } & 7.093.368. & 100,0 \\
\hline
\end{tabular}


Tahela A3_Distribuição do emprego nas mesorregiões do terceiro grupo* - 1997/2007

\begin{tabular}{|c|c|c|c|c|c|c|c|}
\hline \multicolumn{2}{|c|}{ Mesorregião } & \multirow{2}{*}{$\begin{array}{r}\text { Empregos } \\
46.381 \\
\end{array}$} & \multirow{2}{*}{$\frac{\%}{1,0}$} & \multicolumn{2}{|c|}{ Mesorregião } & \multirow{2}{*}{$\begin{array}{r}\text { Empregos } \\
80.046 \\
\end{array}$} & \multirow{2}{*}{$\begin{array}{l}\% \\
1,1 \\
\end{array}$} \\
\hline BA & Centro Sul Baiano & & & MG & Zona da Mata & & \\
\hline MG & Triângulo Mineiro/Alto Paranaíba & 45.979 & 1,0 & SP & São José do Rio Preto & 79.656 & 1,1 \\
\hline SP & Sáo José do Rio Preto & 44.468 & 0,9 & SC & Sul Catarinense & 77.586 & 1,1 \\
\hline $\mathrm{PE}$ & Mata Pernambucana & 43.706 & 0,9 & MG & Oeste de Minas & 69.334 & 1,0 \\
\hline SC & Sul Catarinense & 42.900 & 0,9 & SP & Araraquara & 64.597 & 0,9 \\
\hline SP & Araraquara & 39.678 & 0,8 & PR & Oeste Paranaense & 64.188 & 0,9 \\
\hline MG & Oeste de Minas & 36.105 & 0,8 & RS & Centro Oriental Rio-Grandense & 63.280 & 0,9 \\
\hline ES & Central Espírito-Santense & 34.356 & 0,7 & PE & Mata Pernambucana & 59.821 & 0,8 \\
\hline MG & Vale do Rio Doce & 33.130 & 0,7 & ES & Central Espírito-Santense & 57.173 & 0,8 \\
\hline RJ & Sul Fluminense & 31.784 & 0,7 & PR & Noroeste Paranaense & 56.025 & 0,8 \\
\hline SP & Araçatuba & 27.750 & 0,6 & $\mathrm{GO}$ & Sul Goiano & 52.903 & 0,7 \\
\hline $\mathrm{RN}$ & Leste Potiguar & 27.252 & 0,6 & SP & Araçatuba & 49.025 & 0,7 \\
\hline PA & Metropolitana de Belém & 25.210 & 0,5 & RN & Leste Potiguar & 47.421 & 0,7 \\
\hline SP & Itapetininga & 24.633 & 0,5 & RJ & Sul Fluminense & 46.275 & 0,7 \\
\hline PB & Mata Paraibana & 24.616 & 0,5 & MG & Vale do Rio Doce & 43.611 & 0,6 \\
\hline RS & Centro Oriental Rio-Grandense & 24.248 & 0,5 & SP & Presidente Prudente & 39.615 & 0,6 \\
\hline PR & Oeste Paranaense & 23.318 & 0,5 & RJ & Norte Fluminense & 38.693 & 0,5 \\
\hline PR & Noroeste Paranaense & 22.696 & 0,5 & PA & Metropolitana de Belém & 38.558 & 0,5 \\
\hline RJ & Centro Fluminense & 20.334 & 0,4 & $\mathrm{~PB}$ & Mata Paraibana & 38.311 & 0,5 \\
\hline SC & Grande Florianópolis & 19.674 & 0,4 & SP & Itapetininga & 37.692 & 0,5 \\
\hline SE & Leste Sergipano & 19.427 & 0,4 & PR & Centro Oriental Paranaense & 36.073 & 0,5 \\
\hline RS & Sudeste Rio-Grandense & 18.911 & 0,4 & SC & Grande Florianópolis & 34.712 & 0,5 \\
\hline MG & Norte de Minas & 18.692 & 0,4 & PA & Sudeste Paraense & 34.660 & 0,5 \\
\hline MT & Norte Mato-Grossense & 18.249 & 0,4 & MT & Norte Mato-Grossense & 33.860 & 0,5 \\
\hline SP & Marília & 17.475 & 0,4 & BA & Centro Norte Baiano & 31.266 & 0,4 \\
\hline \multicolumn{2}{|c|}{ Subtotal } & 730.972 & 15,3 & \multicolumn{2}{|c|}{ Subtotal } & 1.274 .381 & 18,0 \\
\hline \multicolumn{2}{|c|}{ Total } & & 100,0 & \multicolumn{2}{|l|}{ Total. } & 7.093.368 & 100,0 \\
\hline
\end{tabular}


Tabela A4_Distribuição do emprego nas mesorregiões do quarto grupo* - 1997/2007

\begin{tabular}{|c|c|c|c|c|c|c|c|}
\hline \multicolumn{2}{|c|}{ Mesorregião } & \multirow{2}{*}{$\begin{array}{r}\text { Empregos } \\
17.442 \\
\end{array}$} & \multirow{2}{*}{$\frac{\%}{0,4}$} & \multicolumn{2}{|c|}{ Mesorregião } & \multirow{2}{*}{$\begin{array}{r}\text { Empregos } \\
30.393 \\
\end{array}$} & \multirow{2}{*}{$\begin{array}{l}\% \\
0,4\end{array}$} \\
\hline SP & Presidente Prudente & & & BA & Centro Sul Baiano & & \\
\hline DF & Distrito Federal & 17.391 & 0,4 & PE & Agreste Pernambucano & 28.031 & 0,4 \\
\hline GO & Sul Goiano & 14.678 & 0,3 & SE & Leste Sergipano & 27.997 & 0,4 \\
\hline SP & Assis & 14.626 & 0,3 & $\mathrm{RJ}$ & Centro Fluminense & 27.568 & 0,4 \\
\hline PA & Sudeste Paraense & 14.498 & 0,3 & PR & Sudoeste Paranaense & 26.832 & 0,4 \\
\hline $\mathrm{RO}$ & Leste Rondoniense & 14.436 & 0,3 & DF & Distrito Federal & 26.075 & 0,4 \\
\hline SC & Serrana & 14.434 & 0,3 & MS & Sudoeste de Mato Grosso do Sul & 24.641 & 0,3 \\
\hline PR & Sudeste Paranaense & 14.052 & 0,3 & MT & Centro-Sul Mato-Grossense & 24.530 & 0,3 \\
\hline PB & Agreste Paraibano & 13.625 & 0,3 & $\mathrm{RO}$ & Leste Rondoniense & 24.453 & 0,3 \\
\hline PR & Centro-Sul Paranaense & 13.296 & 0,3 & PR & Norte Pioneiro Paranaense & 24.125 & 0,3 \\
\hline BA & Centro Norte Baiano & 13.248 & 0,3 & CE & Noroeste Cearense & 24.113 & 0,3 \\
\hline PR & Sudoeste Paranaense & 13.173 & 0,3 & MG & Norte de Minas & 23.374 & 0,3 \\
\hline RJ & Norte Fluminense & 13.156 & 0,3 & SP & Marília & 23.158 & 0,3 \\
\hline MT & Centro-Sul Mato-Grossense & 13.123 & 0,3 & SP & Assis & 23.100 & 0,3 \\
\hline ES & Sul Espírito-Santense & 13.069 & 0,3 & $\mathrm{~PB}$ & Agreste Paraibano & 22.290 & 0,3 \\
\hline PR & Centro Ocidental Paranaense & 13.069 & 0,3 & BA & Sul Baiano & 21.446 & 0,3 \\
\hline MG & Campo das Vertentes & 12.896 & 0,3 & RS & Sudeste Rio-Grandense & 20.861 & 0,3 \\
\hline PR & Norte Pioneiro Paranaense & 12.361 & 0,3 & ES & Noroeste Espírito-Santense & 19.773 & 0,3 \\
\hline PE & Agreste Pernambucano & 11.167 & 0,2 & ES & Litoral Norte Espírito-Santense & 19.560 & 0,3 \\
\hline MS & Sudoeste de Mato Grosso do Sul & 10.534 & 0,2 & MS & Centro Norte de Mato Grosso do Sul & 19.378 & 0,3 \\
\hline MS & Centro Norte de Mato Grosso do Sul & 10.373 & 0,2 & ES & Sul Espírito-Santense & 19.222 & 0,3 \\
\hline ES & Noroeste Espírito-Santense & 10.088 & 0,2 & PI & Centro-Norte Piauiense & 18.223 & 0,3 \\
\hline ES & Litoral Norte Espírito-Santense & 9.817 & 0,2 & SC & Serrana & 18.219 & 0,3 \\
\hline $\mathrm{CE}$ & Noroeste Cearense & 9.651 & 0,2 & MS & Leste de Mato Grosso do Sul & 17.765 & 0,3 \\
\hline BA & Sul Baiano & 9.244 & 0,2 & $\mathrm{PR}$ & Sudeste Paranaense & 17.564 & 0,2 \\
\hline \multicolumn{2}{|c|}{ Subtotal } & 323.447 & 6,8 & \multicolumn{2}{|c|}{ Subtotal } & 572.691 & 8,1 \\
\hline \multicolumn{2}{|c|}{ Total . } & 4.769 .855 & 100,0 & \multicolumn{2}{|c|}{ Total } & 7.093 .368 & 100,0 \\
\hline
\end{tabular}

Fonte: RAIS

(*) 25 Mesorregióes seguintes 
Tabela A5_Distribuição do emprego nas mesorregióes do quinto grupo* - 1997/2007

\begin{tabular}{|c|c|c|c|c|c|c|c|}
\hline \multicolumn{2}{|c|}{ Mesorregião } & \multirow{2}{*}{$\begin{array}{r}\text { Empregos } \\
8.528\end{array}$} & \multirow{2}{*}{$\frac{\%}{0,2}$} & \multicolumn{2}{|c|}{ Mesorregiáo } & \multirow{2}{*}{$\frac{\text { Empregos }}{17.152}$} & \multirow{2}{*}{$\%$} \\
\hline MA & Norte Maranhense & & & MG & Campo das Vertentes & & \\
\hline MG & Central Mineira & 8.493 & 0,2 & MG & Central Mineira & 15.890 & 0,2 \\
\hline RN & Oeste Potiguar & 7.586 & 0,2 & $\mathrm{CE}$ & Sul Cearense & 15.129 & 0,2 \\
\hline MT & Sudoeste Mato-Grossense & 7.372 & 0,2 & PR & Centro-Sul Paranaense & 14.758 & 0,2 \\
\hline MA & Oeste Maranhense & 7.178 & 0,2 & $\mathrm{CE}$ & Norte Cearense & 14.750 & 0,2 \\
\hline PI & Centro-Norte Piauiense & 7.049 & 0,1 & $\mathrm{RN}$ & Oeste Potiguar & 14.370 & 0,2 \\
\hline $\mathrm{CE}$ & Sul Cearense & 6.648 & 0,1 & MA & Norte Maranhense & 14.103 & 0,2 \\
\hline PR & Centro Oriental Paranaense & 6.615 & 0,1 & MT & Sudoeste Mato-Grossense & 13.181 & 0,2 \\
\hline RS & Centro Ocidental Rio-Grandense & 6.000 & 0,1 & PA & Nordeste Paraense & 11.884 & 0,2 \\
\hline RS & Sudoeste Rio-Grandense & 5.754 & 0,1 & RS & Centro Ocidental Rio-Grandense & 11.048 & 0,2 \\
\hline $\mathrm{CE}$ & Norte Cearense & 5.571 & 0,1 & PR & Centro Ocidental Paranaense & 10.711 & 0,2 \\
\hline MS & Leste de Mato Grosso do Sul & 5.349 & 0,1 & MT & Sudeste Mato-grossense & 10.379 & 0,1 \\
\hline RJ & Noroeste Fluminense & 4.984 & 0,1 & CE & Jaguaribe & 9.933 & 0,1 \\
\hline PA & Nordeste Paraense & 4.353 & 0,1 & $\mathrm{BA}$ & Nordeste Baiano & 9.885 & 0,1 \\
\hline $\mathrm{BA}$ & Vale São-Franciscano da Bahia & 4.243 & 0,1 & TO & Ocidental do Tocantins & 9.537 & 0,1 \\
\hline PA & Baixo Amazonas & 4.217 & 0,1 & $\mathrm{GO}$ & Leste Goiano & 9.363 & 0,1 \\
\hline RN & Central Potiguar & 4.061 & 0,1 & RS & Sudoeste Rio-Grandense & 8.687 & 0,1 \\
\hline RJ & Baixadas & 3.981 & 0,1 & MA & Oeste Maranhense & 8.444 & 0,1 \\
\hline PA & Marajó & 3.971 & 0,1 & $\mathrm{RN}$ & Central Potiguar & 7.762 & 0,1 \\
\hline SP & Litoral Sul Paulista & 3.789 & 0,1 & $\mathrm{RO}$ & Madeira-Guaporé & 7.598 & 0,1 \\
\hline MG & Noroeste de Minas & 3.531 & 0,1 & RJ & Noroeste Fluminense & 6.674 & 0,1 \\
\hline PE & Sertão Pernambucano & 3.490 & 0,1 & $\mathrm{PA}$ & Baixo Amazonas & 6.603 & 0,1 \\
\hline MA & Leste Maranhense & 3.327 & 0,1 & MT & Nordeste Mato-Grossense & 5.909 & 0,1 \\
\hline MG & Jequitinhonha & 3.262 & 0,1 & SE & Agreste Sergipano & 5.738 & 0,1 \\
\hline RO & Madeira-Guaporé & 3.207 & 0,1 & $\mathrm{PE}$ & Sertão Pernambucano & 5.579 & 0,1 \\
\hline \multicolumn{2}{|c|}{ Subtotal } & 132.559 & 2,8 & \multicolumn{2}{|c|}{ Subtotal } & 265.067 & 3,7 \\
\hline \multicolumn{2}{|c|}{ Total } & 4.769 .855 & 100,0 & \multicolumn{2}{|c|}{ Total } & 7.093 .368 & 100,0 \\
\hline
\end{tabular}

Fonte: RAIS

$\left.{ }^{*}\right) 25$ Mesorregiōes seguintes 
Tabela A6_Distribuição do emprego nas mesorregiões do sexto Grupo* - 1997/2007

\begin{tabular}{|c|c|c|c|c|c|c|c|}
\hline \multicolumn{2}{|c|}{ Mesorregiáo } & \multirow{2}{*}{$\frac{\text { Empregos }}{3.107}$} & \multirow{2}{*}{$\%$} & \multicolumn{2}{|c|}{ Mesorregiáo } & \multirow{2}{*}{$\frac{\text { Empregos }}{5.466}$} & \multirow{2}{*}{$\%$} \\
\hline MT & Sudeste Mato-Grossense & & & MA & Leste Maranhense & & \\
\hline $\mathrm{GO}$ & Norte Goiano & 3.034 & 0,1 & MG & Noroeste de Minas & 5.428 & 0,1 \\
\hline TO & Ocidental do Tocantins & 2.987 & 0,1 & $\mathrm{GO}$ & Norte Goiano & 5.294 & 0,1 \\
\hline $\mathrm{GO}$ & Leste Goiano & 2.966 & 0,1 & $\mathrm{~PB}$ & Sertâo Paraibano & 4.928 & 0,1 \\
\hline PI & Norte Piauiense & 2.805 & 0,1 & $\mathrm{AC}$ & Vale do Acre & 4.909 & 0,1 \\
\hline $\mathrm{AC}$ & Vale do Acre & 2.521 & 0,1 & MG & Jequitinhonha & 4.673 & 0,1 \\
\hline BA & Nordeste Baiano & 2.517 & 0,1 & GO & Noroeste Goiano & 4.626 & 0,1 \\
\hline $\mathrm{CE}$ & Jaguaribe & 2.514 & 0,1 & $\mathrm{BA}$ & Vale São-Franciscano da Bahia & 4.514 & 0,1 \\
\hline MG & Vale do Mucuri & 2.252 & 0,0 & $\mathrm{RJ}$ & Baixadas & 4.313 & 0,1 \\
\hline $\mathrm{PB}$ & Sertáo Paraibano & 2.242 & 0,0 & PA & Sudoeste Paraense & 4.274 & 0,1 \\
\hline MT & Nordeste Mato-Grossense & 2.211 & 0,0 & MG & Vale do Mucuri & 4.266 & 0,1 \\
\hline $\mathrm{PE}$ & São Francisco Pernambucano & 2.167 & 0,0 & $\mathrm{AL}$ & Agreste Alagoano & 4.194 & 0,1 \\
\hline $\mathrm{AL}$ & Agreste Alagoano & 2.048 & 0,0 & MS & Pantanais Sul Mato-Grossense & 3.937 & 0,1 \\
\hline SE & Agreste Sergipano & 2.030 & 0,0 & $\mathrm{AP}$ & Sul do Amapá & 3.862 & 0,1 \\
\hline $\mathrm{GO}$ & Noroeste Goiano & 1.663 & 0,0 & $\mathrm{TO}$ & Oriental do Tocantins & 3.389 & 0,0 \\
\hline $\mathrm{CE}$ & Centro-Sul Cearense & 1.522 & 0,0 & SP & Litoral Sul Paulista & 3.371 & 0,0 \\
\hline $\mathrm{AP}$ & Sul do Amapá & 1.227 & 0,0 & $\mathrm{CE}$ & Centro-Sul Cearense & 3.356 & 0,0 \\
\hline $\mathrm{CE}$ & Sertôes Cearenses & 1.157 & 0,0 & $\mathrm{BA}$ & Extremo Oeste Baiano & 3.238 & 0,0 \\
\hline MS & Pantanais Sul Mato-Grossense & 1.100 & 0,0 & $\mathrm{PA}$ & Marajó & 3.151 & 0,0 \\
\hline MA & Sul Maranhense & 1.080 & 0,0 & PE & São Francisco Pernambucano & 3.107 & 0,0 \\
\hline $\mathrm{BA}$ & Extremo Oeste Baiano & 1.068 & 0,0 & MA & Sul Maranhense & 3.096 & 0,0 \\
\hline TO & Oriental do Tocantins & 1.054 & 0,0 & $\mathrm{CE}$ & Sertôes Cearenses & 2.778 & 0,0 \\
\hline RR & Norte de Roraima & 978 & 0,0 & RN & Agreste Potiguar & 2.558 & 0,0 \\
\hline PA & Sudoeste Paraense & 921 & 0,0 & PI & Norte Piauiense & 2.472 & 0,0 \\
\hline $\mathrm{RN}$ & Agreste Potiguar & 899 & 0,0 & SE & Sertáo Sergipano & 2.409 & 0,0 \\
\hline PI & Sudeste Piauiense & 851 & 0,0 & MA & Centro Maranhense & 1.734 & 0,0 \\
\hline $\mathrm{PB}$ & Borborema & 849 & 0,0 & PI & Sudeste Piauiense & 1.678 & 0,0 \\
\hline $\mathrm{AL}$ & Sertão Alagoano & 831 & 0,0 & PI & Sudoeste Piauiense & 1.498 & 0,0 \\
\hline MA & Centro Maranhense & 563 & 0,0 & $\mathrm{RR}$ & Norte de Roraima & 1.403 & 0,0 \\
\hline PI & Sudoeste Piauiense & 324 & 0,0 & $\mathrm{~PB}$ & Borborema & 1.206 & 0,0 \\
\hline $\mathrm{AM}$ & Sul Amazonense & 211 & 0,0 & $\mathrm{AL}$ & Sertáo Alagoano & 1.116 & 0,0 \\
\hline SE & Sertâo Sergipano & 167 & 0,0 & $\mathrm{AM}$ & Sul Amazonense & 392 & 0,0 \\
\hline $\mathrm{AC}$ & Vale do Juruá & 148 & 0,0 & $\mathrm{AC}$ & Vale do Juruá & 322 & 0,0 \\
\hline RR & Sul de Roraima & 51 & 0,0 & RR & Sul de Roraima & 180 & 0,0 \\
\hline $\mathrm{AP}$ & Norte do Amapá & 4 & 0,0 & $\mathrm{AM}$ & Sudoeste Amazonense & 82 & 0,0 \\
\hline $\mathrm{AM}$ & Norte Amazonense & 1 & 0,0 & $\mathrm{AP}$ & Norte do Amapá & 64 & 0,0 \\
\hline $\mathrm{AM}$ & Sudoeste Amazonense & 1 & 0,0 & $\mathrm{AM}$ & Norte Amazonense & 26 & 0,0 \\
\hline \multicolumn{2}{|c|}{ Subtotal } & 52.071 & 1,1 & \multicolumn{2}{|c|}{ Subtotal } & 107.310 & 1,5 \\
\hline Total & & 4.769 .855 & 100,0 . & Total & & 7.093.368. & 100,0 \\
\hline
\end{tabular}

Fonte: RAIS

$\left(^{*}\right) 37$ mesorregióes seguintes 
Tabela A7_Distribuição do emprego por mesorregião - Commodities - 1997/2007

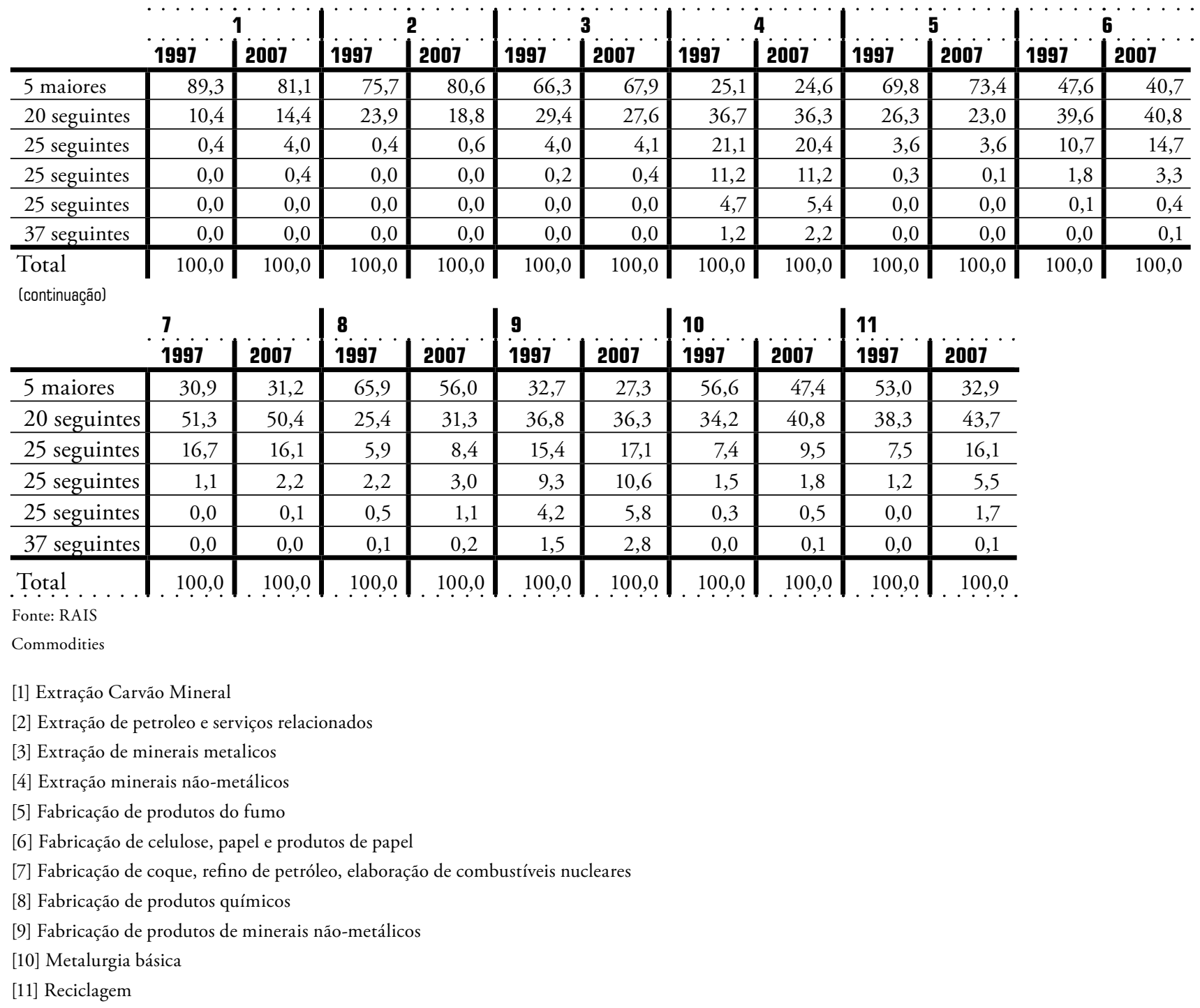


Tabela A8_Distribuição do emprego por mesorregião - Difusora/durável - 1997/2007

\begin{tabular}{|c|c|c|c|c|c|c|c|c|c|c|c|c|}
\hline & \multicolumn{2}{|c|}{1} & \multicolumn{2}{|c|}{2} & \multicolumn{2}{|c|}{3} & \multicolumn{2}{|c|}{4} & \multicolumn{2}{|c|}{5} & \multicolumn{2}{|c|}{6} \\
\hline & 1997 & 2007 & 1997 & 2007 & 1997 & 2007 & 1997 & 2007 & 1997 & 2007 & 1997 & 2007 \\
\hline 5 maiores & 55,0 & 44,0 & 76,1 & 63,9 & 58,0 & 51,6 & 77,9 & 74,7 & 64,1 & 54,8 & 74,2 & 71,7 \\
\hline 20 seguintes & 38,2 & 43,2 & 23,0 & 35,0 & 38,1 & 40,9 & 20,9 & 23,6 & 31,4 & 38,3 & 21,0 & 24,0 \\
\hline 25 seguintes & 5,6 & 9,5 & 0,9 & 1,1 & 3,4 & 6,4 & 1,1 & 1,6 & 3,7 & 5,8 & 4,0 & 3,4 \\
\hline 25 seguintes & 1,0 & 2,7 & 0,0 & 0,0 & 0,5 & 0,9 & 0,1 & 0,1 & 0,7 & 0,9 & 0,8 & 0,8 \\
\hline 25 seguintes & 0,2 & 0,5 & 0,0 & 0,0 & 0,0 & 0,2 & 0,0 & 0,0 & 0,1 & 0,2 & 0,1 & 0,1 \\
\hline 37 seguintes & 0,0 & 0,1 & 0,0 & 0,0 & 0,0 & 0,0 & 0,0 & 0,0 & 0,0 & 0,0 & 0,0 & 0,0 \\
\hline Total & 100,0 & 100,0 & 100,0 & 100,0 & 100,0 & 100,0 & 100,0 & 100,0 & 100,0 & 100,0 & 100,0 & 100,0 \\
\hline
\end{tabular}

(continuação)

\begin{tabular}{l|r|r} 
& \multicolumn{2}{|c}{$\boldsymbol{7}$} \\
\cline { 2 - 3 } & \multicolumn{1}{|c}{$\mathbf{1 9 9 7}$} & \multicolumn{1}{c}{$\mathbf{2 0 0 7}$} \\
\hline 5 maiores & 74,3 & 61,3 \\
\hline 20 seguintes & 21,5 & 33,7 \\
\hline 25 seguintes & 3,2 & 4,0 \\
\hline 25 seguintes & 0,7 & 0,7 \\
\hline 25 seguintes & 0,2 & 0,3 \\
\hline 37 seguintes & 0,0 & 0,1 \\
\hline Total ..... & 100,0 & 100,0
\end{tabular}

Fonte: RAIS

Difusora/Durável

[1] Fabricação de máquinas e equipamentos

[2] Fabricação. de máquinas para escritório e equipamentos de informática

[3] Fabricação de máquinas, aparelhos e materiais elétricos

[4] Fabricação de material eletrônico e de aparelhos e equipamentos de computadores

[5] Fabricação. de equipamentos de instrumentação para usos medico-hospitalares

[6] Fabricação de outros equipamentos de transporte

[7]Fabricaçâo. e montagem de veículos automotores, reboques e carrocerias 
Tabela A9_Distribuição do emprego por mesorregião - Tradicional - 1997/2007

\begin{tabular}{|c|c|c|c|c|c|c|c|c|c|c|c|c|}
\hline & & & & & & & & & & & & \\
\hline & 1997 & 2007 & 1997 & 2007 & 1997 & 2007 & 1997 & 2007 & 1997 & 2007 & 1997 & 2007 \\
\hline 5 maiores & 26,7 & 22,4 & 48,3 & 47,8 & 45,6 & 40,0 & 60,2 & 47,7 & 27,5 & 26,6 & 61,8 & 55,1 \\
\hline 20 seguintes & 41,0 & 40,9 & 36,9 & 36,5 & 37,3 & 40,2 & 30,7 & 38,5 & 49,0 & 48,4 & 23,9 & 27,1 \\
\hline 25 seguintes & 19,0 & 20,3 & 11,2 & 11,2 & 12,4 & 14,2 & 6,9 & 9,9 & 15,8 & 17,1 & 9,8 & 11,3 \\
\hline 25 seguintes & 8,7 & 10,3 & 2,7 & 3,2 & 3,5 & 4,0 & 1,7 & 3,1 & 5,5 & 5,3 & 2,9 & 4,1 \\
\hline 25 seguintes & 3,4 & 4,4 & 0,8 & 1,1 & 1,0 & 1,3 & 0,5 & 0,7 & 1,7 & 1,9 & 1,2 & 1,7 \\
\hline 37 seguintes & 1,2 & 1,8 & 0,1 & 0,2 & 0,2 & 0,3 & 0,1 & 0,1 & 0,5 & 0,7 & 0,4 & 0,7 \\
\hline Total & 100,0 & 100,0 & 100,0 & 100,0 . & 100,0 & 100,0 . & 100,0 & 100,0 . & 100,0 . & 100,0 . & 100,0 & 100,0 \\
\hline
\end{tabular}

(continuação)

\begin{tabular}{l|r|r|r|r|r|r} 
& \multicolumn{1}{|c|}{$\mathbf{9 9 7}$} & $\mathbf{2 0 0 7}$ & $\mathbf{1 9 9 7}$ & $\mathbf{2 0 0 7}$ & \multicolumn{1}{|c|}{$\mathbf{9 9 7}$} & $\mathbf{2 0 0 7}$ \\
\hline 5 maiores & 58,7 & 48,1 & 54,5 & 44,7 & 40,2 & 35,0 \\
\hline 20 seguintes & 30,3 & 38,2 & 32,7 & 37,6 & 39,4 & 42,1 \\
\hline 25 seguintes & 7,8 & 9,6 & 9,1 & 11,8 & 13,6 & 14,9 \\
\hline 25 seguintes & 2,2 & 2,9 & 2,7 & 4,1 & 4,8 & 5,4 \\
\hline 25 seguintes & 0,8 & 0,9 & 0,9 & 1,5 & 1,6 & 2,0 \\
\hline 37 seguintes & 0,1 & 0,2 & 0,2 & 0,3 & 0,4 & 0,6 \\
\hline Total . . . . & 100,0 & 100,0 & 100,0 & 100,0 & 100,0 & 100,0
\end{tabular}

Fonte: RAIS

Tradicional

[1] Fabricação de produtos alimentícios e bebidas

[2] Fabricação de produtos têxteis

[3] Confecção de artigos do vestuário e acessórios

[4] Preparação de couros e fabrç. de artefatos de couro

[5] Fabricação de produtos de madeira

[6] Edição, impressão e reprodução de gravaçôes

[7] Fabricação de artigos de borracha e plástico

[8] Fabricaçấo de produtos de metal - exclusive máquinas e equipamentos

[9] Fabricação de móveis e indústrias diversas 
Anexo C

Índice de densidade nas mesorregiões dos grupos inferior e médio-inferior

Tabela A10_ Índice de densidade por mesorregião - Grupo inferior" - 1997/2007

\begin{tabular}{|c|c|c|c|c|c|}
\hline UF & Mesorregião & Índice & UF & Mesorregião & Índice \\
\hline PA & Marajó & 0,49 & $\mathrm{CE}$ & Sul Cearense & 0,49 \\
\hline $\mathrm{MG}$ & Norte de Minas & 0,49 & RN & Oeste Potiguar & 0,49 \\
\hline $\mathrm{GO}$ & Sul Goiano & 0,47 & MS & Pantanais Sul Mato-Grossense & 0,46 \\
\hline $\mathrm{PA}$ & Metropolitana de Belém & 0,45 & $\mathrm{CE}$ & Norte Cearense & 0,44 \\
\hline $\mathrm{PB}$ & Agreste Paraibano & 0,44 & PA & Metropolitana de Belém & 0,41 \\
\hline MS & Centro Norte de Mato Grosso do Sul & 0,43 & MG & Noroeste de Minas & 0,41 \\
\hline $\mathrm{RN}$ & Central Potiguar & 0,42 & $\mathrm{BA}$ & Centro-Norte Baiano & 0,41 \\
\hline MG & Noroeste de Minas & 0,39 & $\mathrm{MG}$ & Norte de Minas & 0,41 \\
\hline $\mathrm{PR}$ & Centro Oriental Paranaense & 0,38 & $\mathrm{PE}$ & Agreste Pernambucano & 0,37 \\
\hline $\mathrm{RN}$ & Oeste Potiguar & 0,38 & $\mathrm{RO}$ & Madeira-Guaporé & 0,36 \\
\hline $\mathrm{GO}$ & Norte Goiano & 0,37 & SE & Agreste Sergipano & 0,36 \\
\hline RS & Centro Ocidental Rio-Grandense & 0,36 & PI & Centro-Norte Piauiense & 0,34 \\
\hline SP & Litoral Sul Paulista & 0,35 & MG & Vale do Mucuri & 0,33 \\
\hline $\mathrm{CE}$ & Noroeste Cearense & 0,34 & MA & Sul Maranhense & 0,32 \\
\hline $\mathrm{CE}$ & Sul Cearense & 0,34 & SE & Sertão Sergipano & 0,32 \\
\hline RJ & Baixadas & 0,33 & $\mathrm{BA}$ & Centro-Sul Baiano & 0,32 \\
\hline MT & Sudeste Mato-Grossense & 0,32 & $\mathrm{TO}$ & Ocidental do Tocantins & 0,31 \\
\hline $\mathrm{DF}$ & Distrito Federal & 0,30 & $\mathrm{BA}$ & Sul Baiano & 0,29 \\
\hline MT & Nordeste Mato-Grossense & 0,30 & RS & Sudoeste Rio-Grandense & 0,29 \\
\hline PA & Baixo Amazonas & 0,29 & $\mathrm{AC}$ & Vale do Acre & 0,28 \\
\hline $\mathrm{RO}$ & Madeira-Guaporé & 0,28 & PA & Baixo Amazonas & 0,28 \\
\hline $\mathrm{CE}$ & Norte Cearense & 0,27 & DF & Distrito Federal & 0,28 \\
\hline $\mathrm{AC}$ & Vale do Acre & 0,26 & PA & Sudoeste Paraense & 0,25 \\
\hline RS & Sudoeste Rio-Grandense & 0,26 & $\mathrm{CE}$ & Centro-Sul Cearense & 0,25 \\
\hline $\mathrm{GO}$ & Noroeste Goiano & 0,26 & PA & Marajó & 0,24 \\
\hline MA & Oeste Maranhense & 0,24 & $\mathrm{GO}$ & Leste Goiano & 0,22 \\
\hline $\mathrm{BA}$ & Centro-Norte Baiano & 0,23 & PA & Nordeste Paraense & 0,21 \\
\hline $\mathrm{MG}$ & Vale do Mucuri & 0,22 & $\mathrm{AP}$ & Sul do Amapá & 0,20 \\
\hline PE & Agreste Pernambucano & 0,21 & $\mathrm{AL}$ & Agreste Alagoano & 0,20 \\
\hline $\mathrm{CE}$ & $\begin{array}{r}\text { Jaguaribe } \\
\end{array}$ & 0,20 & $\mathrm{RJ}$ & Baixadas & 0,19 \\
\hline PI & Centro-Norte Piauiense & 0,20 & $\mathrm{MG}$ & Jequitinhonha & 0,19 \\
\hline SE & Agreste Sergipano & 0,19 & TO & Oriental do Tocantins & 0,19 \\
\hline PI & Norte Piauiense & 0,19 & $\mathrm{BA}$ & Nordeste Baiano & 0,19 \\
\hline $\mathrm{PE}$ & São Francisco Pernambucano & 0,19 & MA & Oeste Maranhense & 0,18 \\
\hline MS & Pantanais Sul Mato-Grossense & 0,19 & SP & Litoral Sul Paulista & 0,18 \\
\hline $\mathrm{BA}$ & Vale São-Franciscano da Bahia & 0,19 & RN & Agreste Potiguar & 0,18 \\
\hline
\end{tabular}


Tabela A10_ Índice de densidade por mesorregião - Grupo inferior" $\mathbf{- 1 9 9 7 / 2 0 0 7}$

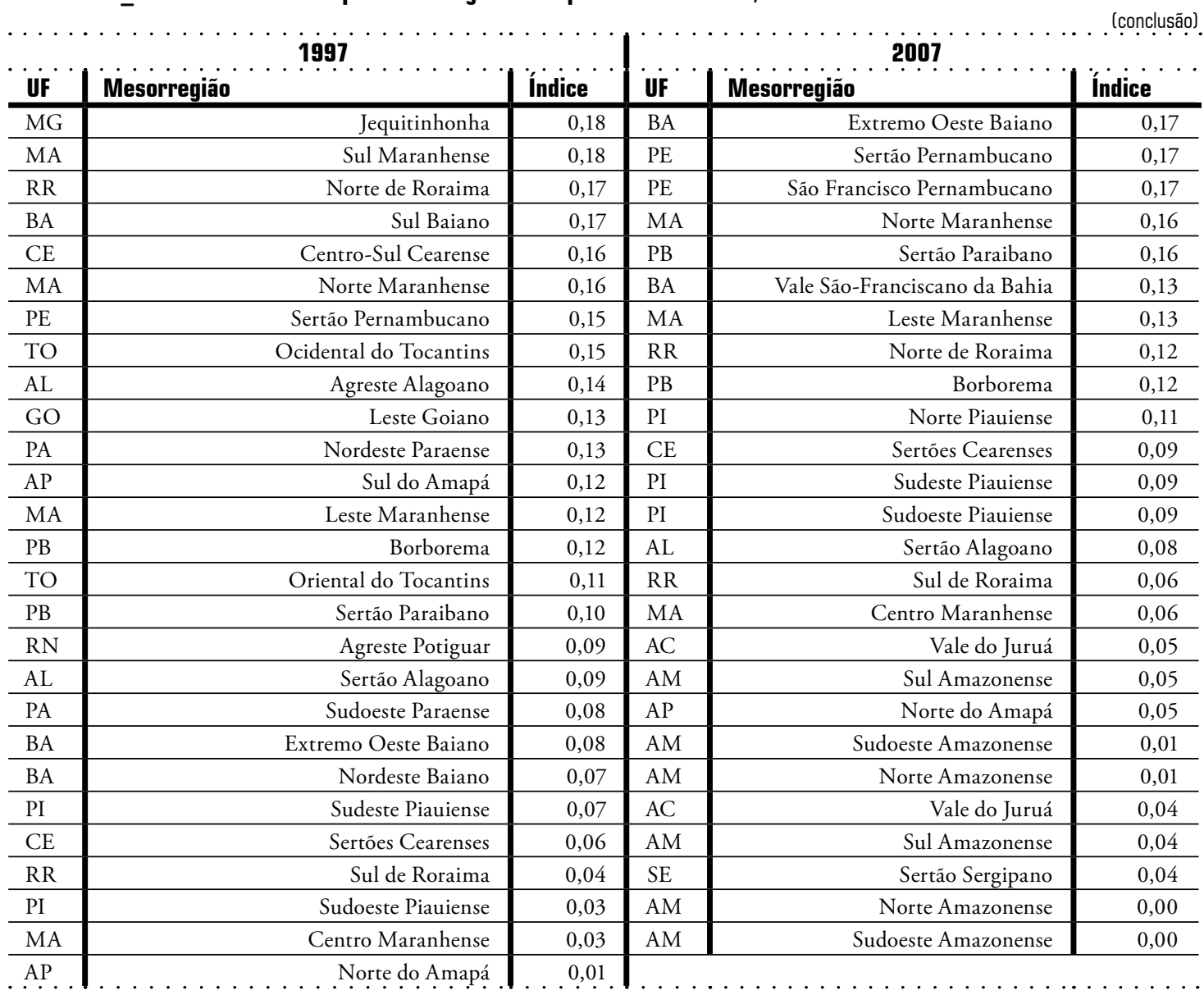

Fonte: RAIS

$\left({ }^{*}\right)$ Valor do índice abaixo de 0,5 
Tabela A11_índice de densidade por mesorregião - Grupo médio inferior* - 1997/2007

\begin{tabular}{|c|c|c|c|c|c|}
\hline UF & Mesorregião & Índice & UF & Mesorregião & Índice \\
\hline SP & Assis & 0,95 & MG & Zona da Mata & 0,96 \\
\hline PR & Sudoeste Paranaense & 0,94 & $\mathrm{GO}$ & Centro Goiano & 0,95 \\
\hline SC & Grande Florianópolis & 0,93 & SC & Grande Florianópolis & 0,91 \\
\hline MG & Zona da Mata & 0,92 & $\mathrm{PR}$ & Centro Ocidental Paranaense & 0,90 \\
\hline ES & Sul Espírito-Santense & 0,91 & MS & Sudoeste de Mato Grosso do Sul & 0,88 \\
\hline MT & Sudoeste Mato-Grossense & 0,89 & ES & Sul Espírito-Santense & 0,85 \\
\hline PR & Centro-Sul Paranaense & 0,88 & $\mathrm{RN}$ & Leste Potiguar & 0,85 \\
\hline ES & Noroeste Espírito-Santense & 0,88 & MG & Campo das Vertentes & 0,80 \\
\hline MG & Campo das Vertentes & 0,83 & $\mathrm{~PB}$ & Mata Paraibana & 0,76 \\
\hline MG & Triângulo Mineiro/Alto Paranaíba & 0,83 & ES & Central Espírito-Santense & 0,74 \\
\hline $\mathrm{RN}$ & Leste Potiguar & 0,81 & $\mathrm{PR}$ & Centro-Sul Paranaense & 0,73 \\
\hline GO & Centro Goiano & 0,80 & MG & Vale do Rio Doce & 0,73 \\
\hline PE & Metropolitana de Recife & 0,80 & PA & Sudeste Paraense & 0,69 \\
\hline ES & Litoral Norte Espírito-Santense & 0,78 & $\mathrm{RO}$ & Leste Rondoniense & 0,66 \\
\hline RS & Noroeste Rio-Grandense & 0,78 & MT & Sudeste Mato-Grossense & 0,65 \\
\hline MG & Central Mineira & 0,77 & PE & Metropolitana de Recife & 0,62 \\
\hline PR & Norte Pioneiro Paranaense & 0,77 & MT & Centro-Sul Mato-Grossense & 0,61 \\
\hline MG & Vale do Rio Doce & 0,76 & MT & Nordeste Mato-Grossense & 0,60 \\
\hline PB & Mata Paraibana & 0,75 & BA & Metropolitana de Salvador & 0,58 \\
\hline RJ & Metropolitana do Rio de Janeiro & 0,74 & RS & Sudeste Rio-Grandense & 0,57 \\
\hline RS & Centro Oriental Rio-Grandense & 0,74 & SE & Leste Sergipano & 0,56 \\
\hline SP & Presidente Prudente & 0,72 & RN & Central Potiguar & 0,55 \\
\hline ES & Central Espírito-Santense & 0,72 & RJ & Metropolitana do Rio de Janeiro & 0,55 \\
\hline PR & Oeste Paranaense & 0,71 & RJ & Noroeste Fluminense & 0,54 \\
\hline RS & Sudeste Rio-grandense & 0,70 & $\mathrm{CE}$ & Noroeste Cearense & 0,54 \\
\hline BA & Centro Sul Baiano & 0,67 & $\mathrm{GO}$ & Noroeste Goiano & 0,54 \\
\hline RJ & Norte Fluminense & 0,65 & $\mathrm{~PB}$ & Agreste Paraibano & 0,52 \\
\hline SE & Leste Sergipano & 0,62 & MS & Centro Norte de Mato Grosso do Sul & 0,52 \\
\hline $\mathrm{RO}$ & Leste Rondoniense & 0,60 & $\mathrm{GO}$ & Norte Goiano & 0,52 \\
\hline MS & Leste de Mato Grosso do Sul & 0,59 & CE & Jaguaribe & 0,51 \\
\hline RJ & Noroeste Fluminense & 0,56 & RS & Centro Ocidental Rio-Grandense & 0,50 \\
\hline MS & Sudoeste de Mato Grosso do Sul & 0,53 & MT & Centro-Sul Mato-Grossense & 0,52 \\
\hline BA & Metropolitana de Salvador & 0,52 & PA & Sudeste Paraense & 0,51 \\
\hline
\end{tabular}

Fonte: RAIS

$\left.{ }^{*}\right)$ Valor do índice de 0,5 a menos de 1 


\begin{tabular}{|c|c|}
\hline$\ldots \ldots \ldots \ldots \ldots$ & $\begin{array}{l}\text { tivas microrregiões e municípios } \\
\ldots \ldots \ldots \ldots \ldots \ldots \ldots \ldots \ldots \ldots \ldots \ldots \ldots \\
\text { le do Itajaí }\end{array}$ \\
\hline Microrregiões & Municípios \\
\hline Blumenau & $\begin{array}{l}\text { Municípios: Apiúna, Ascurra, Benedito Novo, Blumenau, Bo- } \\
\text { tuverá, Brusque, Doutor Pedrinho, Gaspar, Guabiruba, In- } \\
\text { daial, Luiz Alves, Pomerode, Rio dos Cedros, Rodeio, Timbó }\end{array}$ \\
\hline Itajaí & $\begin{array}{l}\text { Balneário Camboriú, Balneário Piçarras, Barra Velha, Bom- } \\
\text { binhas, Camboriú, Ilhota, Itajaí, Itapema, Navegantes, Penha, } \\
\text { Porto Belo, São João do Itaperiú }\end{array}$ \\
\hline Ituporanga & $\begin{array}{l}\text { Agrolândia, Atalanta, Chapadão do Lageado, Imbuia, } \\
\text { Ituporanga, Petrolândia, Vidal Ramos }\end{array}$ \\
\hline Rio do Sul & $\begin{array}{l}\text { Agronômica, Aurora, Braço do Trombudo, Dona Emma, Ibi- } \\
\text { rama, José Boiteux, Laurentino, Lontras, Mirim Doce, Pouso } \\
\text { Redondo, Presidente Getúlio, Presidente Nereu, Rio do Cam- } \\
\text { po, Rio do Oeste, Rio do Sul, Salete, Taió, Trombudo Central, } \\
\text { Vitor Meireles, Witmarsum }\end{array}$ \\
\hline \multicolumn{2}{|c|}{ Mesorregião: Nordeste Rio-Grandense } \\
\hline Microrregiões & Municípios \\
\hline Caxias do Sul & $\begin{array}{l}\text { Antônio Prado, Bento Gonçalves, Boa Vista do Sul, Carlos } \\
\text { Barbosa, Caxias do Sul, Coronel Pilar, Cotiporã, Fagundes } \\
\text { Varela, Farroupilha, Flores da Cunha, Garibaldi, Monte Be- } \\
\text { lo do Sul, Nova Pádua, Nova Roma do Sul, Santa Tereza, São } \\
\text { Marcos, Veranópolis, Vila Flores }\end{array}$ \\
\hline Guaporé & $\begin{array}{l}\text { André da Rocha, Anta Gorda, Arvorezinha, Dois Lajeados, } \\
\text { Guabiju, Guaporé, Ilópolis, Itapuca,Montauri, Nova Alvora- } \\
\text { da, Nova Araçá, Nova Bassano, Nova Prata, Paraí, Protásio Al- } \\
\text { ves, Putinga, São Jorge, São Valentim do Sul, Serafina Corrêa, } \\
\text { União da Serra, Vista Alegre do Prata }\end{array}$ \\
\hline Vacaria & $\begin{array}{l}\text { Bom Jesus, Cambará do Sul, Campestre da Serra, Capão } \\
\text { Bonito do Sul, Esmeralda, Ipê, Jaquirana, Lagoa Vermelha, } \\
\text { Monte Alegre dos Campos, Muitos Capóes, Pinhal da Serra, } \\
\text { São Francisco de Paula, São José dos Ausentes, Vacaria }\end{array}$ \\
\hline
\end{tabular}




\begin{tabular}{l|l}
\hline \multicolumn{1}{c}{ Microrregióes } & \multicolumn{1}{c}{ Mesorregiáo: Norte Catarinense } \\
\hline \multirow{2}{*}{ Canoinhios } \\
\hline Joinville & $\begin{array}{l}\text { Bela Vista do Toldo, Canoinhas, Irineópolis, } \\
\text { Itaiópolis, Mafra, Major Vieira, Monte Castelo, Papanduva, } \\
\text { Porto União, Santa Terezinha, Timbó Grande, Três Barras }\end{array}$ \\
\hline São Bento do Sul & $\begin{array}{l}\text { Araquari, Balneário Barra do Sul, Corupá, Garuva, } \\
\text { Guaramirim, Itapoá, Jaraguá do Sul, Joinville, Massaranduba, } \\
\text { São Francisco do Sul, Schroeder }\end{array}$ \\
\hline
\end{tabular}

\section{Mesorregião: Oeste de Minas}

\begin{tabular}{|c|c|}
\hline Microrregiões & Municípios \\
\hline Piumh & $\begin{array}{l}\text { Antônio Prado, Bento Gonçalves, Boa Vista do Sul, } \\
\text { Carlos Barbosa, Caxias do Sul, Coronel Pilar, Cotiporã, } \\
\text { Fagundes Varela, Farroupilha, Flores da Cunha, Garibaldi, } \\
\text { Monte Belo do Sul, Nova Pádua, Nova Roma do Sul, } \\
\text { Santa Tereza, São Marcos, Veranópolis, Vila Flores }\end{array}$ \\
\hline Divinópolis & $\begin{array}{l}\text { André da Rocha, Anta Gorda, Arvorezinha, Dois Lajeados, } \\
\text { Guabiju, Guaporé, Ilópolis, Itapuca,Montauri, Nova } \\
\text { Alvorada, Nova Araçá, Nova Bassano, Nova Prata, Paraí, } \\
\text { Protásio Alves, Putinga, São Jorge, São Valentim do Sul, } \\
\text { Serafina Corrêa, União da Serra, Vista Alegre do Prata }\end{array}$ \\
\hline Formiga & $\begin{array}{l}\text { Arcos, Camacho, Córrego Fundo, Formiga, Itapecerica, Pains, } \\
\text { Pedra do Indaiá, Pimenta }\end{array}$ \\
\hline Campo Belo & $\begin{array}{l}\text { Aguanil, Campo Belo, Cana Verde, Candeias, Cristais, } \\
\text { Perdóes, Santana do Jacaré }\end{array}$ \\
\hline Oliveira & $\begin{array}{l}\text { Bom Sucesso, Carmo da Mata, Carmópolis de Minas, } \\
\text { Ibituruna, Oliveira, Passa Tempo, Piracema, Santo Antônio } \\
\text { do Amparo, São Francisco de Paula }\end{array}$ \\
\hline
\end{tabular}

Mesorregião: Noroeste Espírito-Santense

\begin{tabular}{l|l}
\hline \multicolumn{1}{c|}{ Microrregióes } & \multicolumn{1}{c}{ Municípios } \\
\hline Barra de Sáo Francisco & $\begin{array}{l}\text { Água Doce do Norte, Barra de Sáo Francisco, Ecoporanga, } \\
\text { Mantenópolis }\end{array}$ \\
\hline Nova Venécia & $\begin{array}{l}\text { Águia Branca, Boa Esperança, Nova Venécia, São Gabriel da } \\
\text { Palha, Vila Pavão, Vila Valério }\end{array}$ \\
\hline Colatina & Alto Rio Novo, Baixo Guandu, Colatina, Governador \\
Lindenberg, Marilândia, Pancas, São Domingos do Norte
\end{tabular}




\begin{tabular}{|c|c|}
\hline \multicolumn{2}{|c|}{ Mesorregião: Norte Fluminense } \\
\hline Microrregióes & Municípios \\
\hline Campos dos Goytacazes & $\begin{array}{l}\text { Campos dos Goytacazes, Cardoso Moreira, São Francisco de } \\
\text { Itabapoana, São Fidélis, São João da Barra }\end{array}$ \\
\hline Macaé & Carapebus, Conceição de Macabu, Macaé, Quissamã \\
\hline \multicolumn{2}{|c|}{ Mesorregião: Leste do Mato Grosso do Sul } \\
\hline Microrregióes & Municípios \\
\hline Cassilândia & Cassilândia, Chapadão do Sul, Costa Rica \\
\hline Paranaíba & Aparecida do Taboado, Inocência, Paranaíba, Selvíria \\
\hline Três Lagoas & $\begin{array}{l}\text { Água Clara, Brasilândia, Ribas do Rio Pardo, } \\
\text { Santa Rita do Pardo, Três Lagoas }\end{array}$ \\
\hline Nova Andradina & $\begin{array}{l}\text { Anaurilândia, Bataguassu, Batayporã, Nova Andradina, } \\
\text { Taquarussu }\end{array}$ \\
\hline \multicolumn{2}{|c|}{ Mesorregião: Sul Goiano } \\
\hline Microrregiões & Municípios \\
\hline Sudoeste de Goiás & $\begin{array}{l}\text { Aparecida do Rio Doce, Aporé, Caiapônia, Castelândia, Cha- } \\
\text { padão do Céu, Doverlândia, Jataí, Maurilândia, Mineiros, } \\
\text { Montividiu, Palestina de Goiás, Perolândia, Portelândia,Rio } \\
\text { Verde, Santa Helena de Goiás, Santa Rita do Araguaia, Santo } \\
\text { Antônio da Barra, Serranópolis }\end{array}$ \\
\hline Vale do Rio dos Bois & $\begin{array}{l}\text { Acreúna, Campestre de Goiás, Cezarina, Edealina, Edéia, In- } \\
\text { diara, Jandaia, Palmeiras de Goiás, Palminópolis, Paraúna, } \\
\text { São João da Paraúna, Turvelândia, Varjão }\end{array}$ \\
\hline Meia Ponte & $\begin{array}{l}\text { Água Limpa, Aloândia, Bom Jesus de Goiás, Buriti Alegre, } \\
\text { Cachoeira Dourada, Caldas Novas, Cromínia, Goiatuba, Ina- } \\
\text { ciolândia, Itumbiara, Joviânia, Mairipotaba, Marzagão, Mor- } \\
\text { rinhos, Panamá, Piracanjuba, Pontalina, Porteirão, Professor } \\
\text { Jamil, Rio Quente, Vicentinopólis }\end{array}$ \\
\hline Pires do Rio & $\begin{array}{l}\text { Cristianópolis, Gameleira de Goiás, Orizona, Palmelo, Pi- } \\
\text { res do Rio, Santa Cruz de Goiás, Sáo Miguel do Passa Quatro, } \\
\text { Silvânia, Urutaí, Vianópolis }\end{array}$ \\
\hline Catalão & $\begin{array}{l}\text { Anhanguera, Campo Alegre de Goiás, Catalão, Corumbaíba, } \\
\text { Cumari, Davinópolis, Goiandira, Ipameri, Nova Aurora, } \\
\text { Ouvidor, Três Ranchos }\end{array}$ \\
\hline Quirinópolis & $\begin{array}{l}\text { Cachoeira Alta, Caçu, Gouvelândia, Itajá, Itarumã, Lagoa } \\
\text { Santa, Paranaiguara, Quirinópolis, São Simão . . . . . . . . . }\end{array}$ \\
\hline
\end{tabular}


